
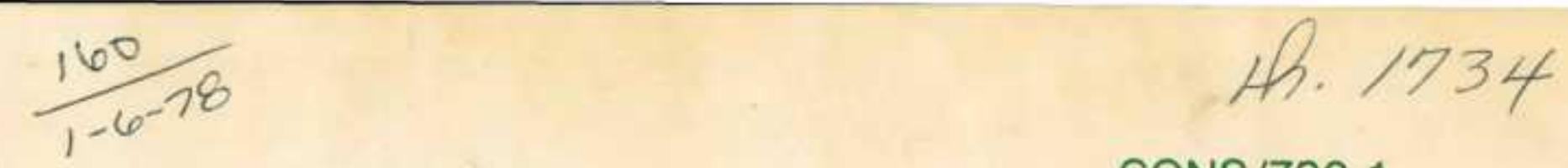

CONS/733-1

NASA CR-135262

\title{
IMPROVED CERAMIC HEAT EXCHANGE MATERIAL
}

H. L. McCollister

OWENS-ILLINOIS, INC.

Toledo, Ohio

September 1977

Prepared for the

NATIONAL AERONAUTICS AND SPACE ADMINISTRATION Lewis Research Center

Cleveland, Ohio 44135

Contract NAS 3-19733

As a part of the

ENERGY RESEARCH AND

DEVELOPMENT ADMINISTRATION

Division of Transportation Energy Conservation

Heat Engine Highway Vehicle Systems Program 


\section{DISCLAIMER}

This report was prepared as an account of work sponsored by an agency of the United States Government. Neither the United States Government nor any agency Thereot, nor any of their employees, makes any warranty, express or implied, or assumes any legal liability or responsibility for the accuracy, completeness, or usefulness of any information, apparatus, product, or process disclosed, or represents that its use would not infringe privately owned rights. Reference herein to any specific commercial product, process, or service by trade name, trademark, manufacturer, or otherwise does not necessarily constitute or imply its endorsement, recommendation, or favoring by the United States Government or any agency thereof. The views and opinions of authors expressed herein do not necessarlly state or reflect those of the United States Government or any agency thereof. 


\section{DISCLAIMER}

Portions of this document may be illegible in electronic image products. Images are produced from the best available original document. 


\begin{tabular}{|c|c|c|c|}
\hline $\begin{array}{l}\text { 1. Aleori No. } \\
\text { HASA CR-135262 }\end{array}$ & 2. Govinnment Aexision No. & \multicolumn{2}{|c|}{ J. Recigient's Corateg No } \\
\hline \multirow{2}{*}{\multicolumn{2}{|c|}{$\begin{array}{l}\text { 4. Trilu and subtik } \\
\text { Iaproved Coranic Heat Exchange Hateriat }\end{array}$}} & \multicolumn{2}{|c|}{$\begin{array}{l}\text { 5. Reperi Don } \\
\text { Septenber } 1977\end{array}$} \\
\hline & & \multicolumn{2}{|c|}{ 6. Perlorming Orapusalien Codt } \\
\hline \multirow{2}{*}{ 7. Alutharts } & \multirow[b]{2}{*}{ - } & \multirow{2}{*}{\multicolumn{2}{|c|}{ B. Pertormm Oreunizotion flapost Ne. }} \\
\hline & & & \\
\hline \multicolumn{2}{|c|}{ 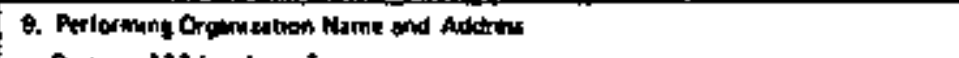 } & \multicolumn{2}{|l|}{ 10. Work Unit Ho. } \\
\hline \multirow{2}{*}{$\begin{array}{l}\text { Orens-litinots, the. } \\
\text { P. O. Box } 1035 \\
\text { Toledo, ohio } 43466\end{array}$} & & & $\begin{array}{l}\text { W. Constoct ar Grunt ka. } \\
\text { MAS 3-19733 }\end{array}$ \\
\hline & & \multirow{2}{*}{\multicolumn{2}{|c|}{$\begin{array}{l}\text { 13. Type of Heport and Fertad Cavtied } \\
\text { Contrattor hepart }\end{array}$}} \\
\hline \multirow{2}{*}{\multicolumn{2}{|c|}{ 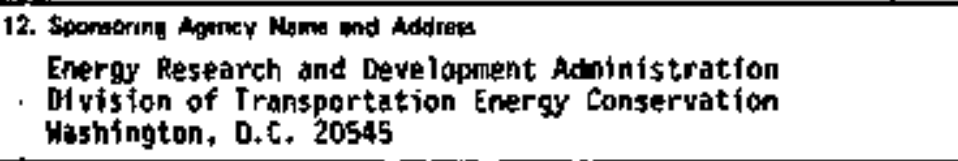 }} & & \\
\hline & & \multicolumn{2}{|c|}{$\begin{array}{l}\text { 14. Sponsorwn Apency code Report tho } \\
\text { C3HS/733-1 }\end{array}$} \\
\hline \multicolumn{4}{|c|}{ 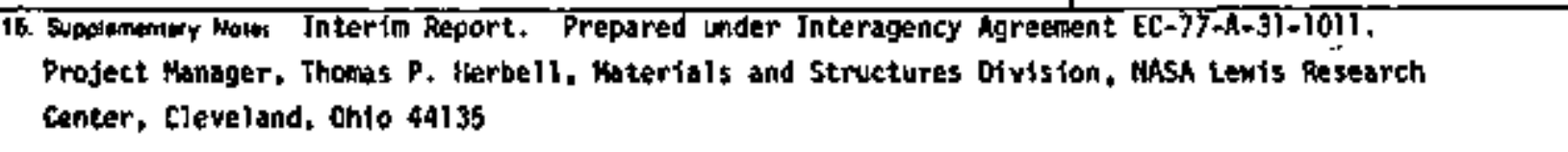 } \\
\hline \multicolumn{4}{|c|}{ 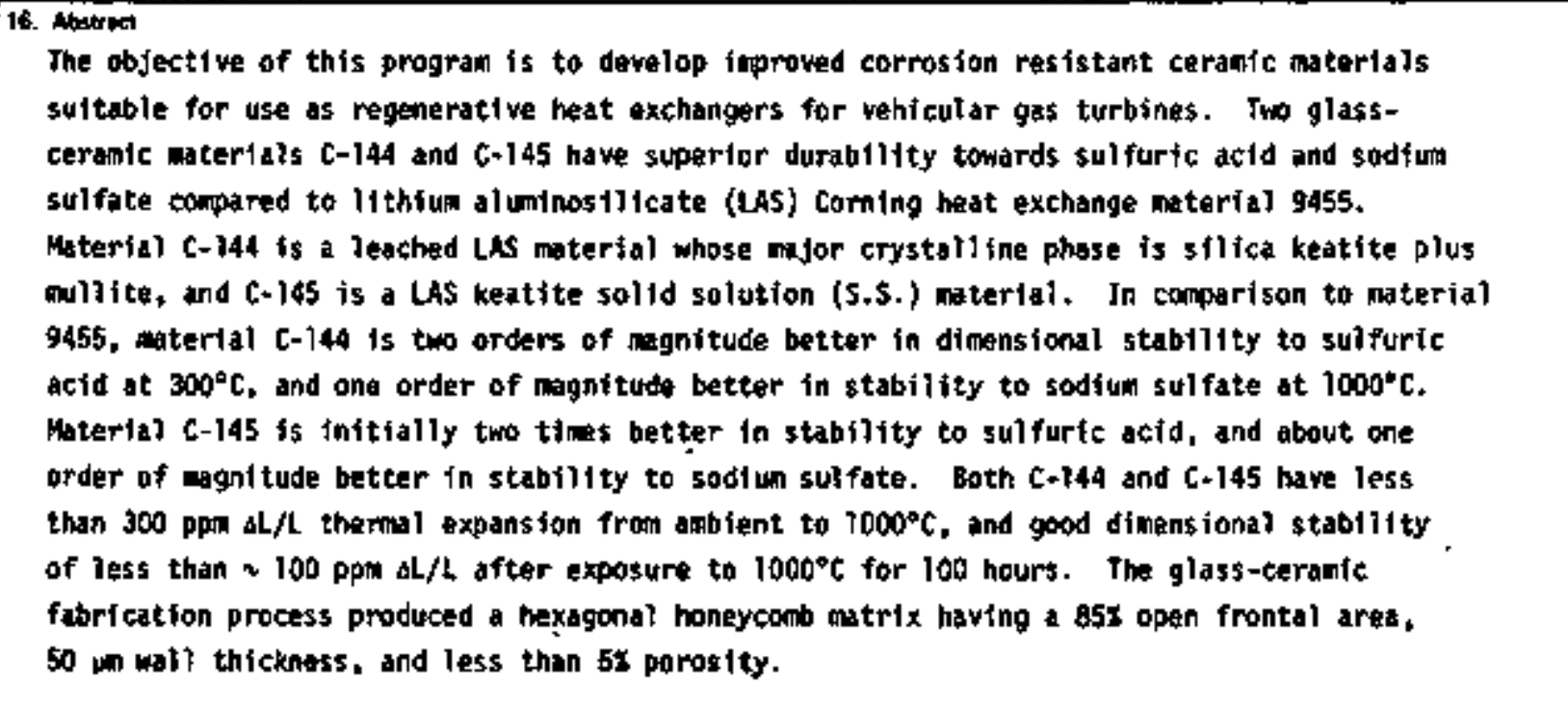 } \\
\hline $\begin{array}{l}\text { 17. Key Wordh ISugested or AuhoriatI } \\
\text { Ceranic } \\
\text { Heat exchangers } \\
\text { Corrosion resistant }\end{array}$ & $\left\{\begin{array}{l}10 \text { OAtuib } \\
\text { Uncla } \\
\text { STAR } \\
\text { ERDA }\end{array}\right.$ & unilfited & \\
\hline 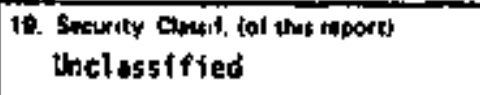 & $\begin{array}{l}\text { 7h. Securny Closint. for the pappl } \\
\text { Unclassifted }\end{array}$ & $\begin{array}{l}\text { 2r. No. al Pupen } \\
\text { 34 }\end{array}$ & $\begin{array}{l}\text { 22. Prise" } \\
\text { 103 }\end{array}$ \\
\hline
\end{tabular}

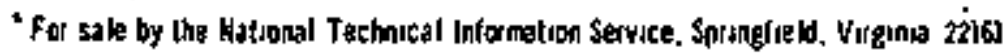


The objective of this program is to develop improved corrosion resistant ceramic materials suitable for use as regenerative heat exchangers for vehicular gas turbines. The major material requirements are low thermal expansion up to $1000^{\circ} \mathrm{C}$, Iong time diansional stability up to $1000^{\circ} \mathrm{C}$, the ability to operate at least for short times up to $1100^{\circ} \mathrm{C}$, and corrosion resistance.

In Task I, four crystalline glass-ceramic materials were studied in solid form as $2.5 \mathrm{~cm} 0.0 . \times 3.8 \mathrm{~cm}$ rods. All materlals $1,2, C-144$, and $C-145$ have improved resistance to chemical attack resulting from the presence of sulfuric acid and sodium salts which limits the 1 ife of Corning LAS 9455 heat exchange material.

Material I is composed of high quartz SS, material 2 contains keatite SS plus mullite, material C-144 is a leached LAS material whose major crystalline phase is silfca keatite plus mulltte, and material $\mathrm{C}-145$ is composed of keatite $\$ S$.

Three of the candfdate materials $2, C-144$, and $C-145$, have strength, thermal expansion, thermal dimensional stability, and phase stability either better than or comparable to material 9455.

The mast severe sulfuric acid attack on the candidate materials was more than an order of magnitude less than solid material 9454 . Solid materials $\mathrm{C}-144$ and $\mathrm{C}-145$ showed no attack from sodium while materials 1 and 2 were marginally better than material 9454.

Materials C-144 and $\mathrm{C}-145$ were chosen, based on their excellent resistance to sulfuric acid and sodiun sulfate, to be fabricated into honeycomb matrix for property testing in Task II.

Results indicate that material C-144 is two orders of magnitude better than Corning LAS matrix 9455 in dinensional stability to sulfuric acid at $300^{\circ} \mathrm{C}$. Material $\mathrm{C}=145$ is twice as good as 9455 in dimensional stability to sulfuric acid after three exposure cycles and is about equal to 9455 after six cycles.

Sodium sulfate corrosion tests indicate that material C-144 is one order of magnitude better than material 9455 in stability to sodium $\$$ ulfate at $1000^{\circ} \mathrm{C}$ after $\mathrm{six}$ exposure cycles. Material C-145 is one order of magnitude better than 9455 after three cycles and about four times better after six exposure cycles.

Both $C-144$ and $C-145$ have less than $300 \mathrm{ppm} \Delta L / L$ thermal expansion from ambient to $1000^{\circ} \mathrm{C}$, and good dimensional stability of less than $\approx 100 \mathrm{ppm} \Delta \mathrm{L} / \mathrm{L}$ change in length after exposure to $1000^{\circ} \mathrm{C}$ for 100 hours. Materials 9455 and $\mathrm{C}-145$ have better dimensional stability at $1100^{\circ} \mathrm{C}$ than material $\mathrm{C}-144$ which contracts about $300 \mathrm{ppm} \Delta \mathrm{L} / \mathrm{L}$ after 10 hours whtle materials 9455 and $C-145$ expand less than $40 \mathrm{ppm} \Delta \mathrm{L} / \mathrm{L}$.

The glass-ceramic fabrication process of $C-144$ and $C-145$ produced a hexagonal isotropic honeycomb matrix having a passage diameter of 700 um (0.028 jn.), 50 um $(0.002$ in.) wall thickness, 170 passages $/ \mathrm{cm}^{2}\left(1100 / \mathrm{in}^{2}\right), 85 \%$ open frontal area, and less than $5 \mathrm{~g}$ porosity. Because of the much thinner 50 w wal], $450 \mathrm{kPa}$ (65 psf) tensiJe strengths measured perpendicular to the open passages of $c-144$ and $C-145$ are 10 w compared to the thicker walled (130-305 $\mu \mathrm{m}) 9455$ anisotropic matrix which has a tenstTe strength of $1800 \mathrm{KPa}(260 \mathrm{psi})$ in the radial direction and $4800 \mathrm{KPa}$ (700 psi) in the tangential direction. 


\section{Table of Contents}

Sumary

Page

Table of Contents

List of Tables

List of Figures

1. Introduction 1

2. Results and Discussion of Task I - Bulk Properties

2.1 Sulfuric Acid

2.2 Sodiun Sulfate

2.3 Thermat Expansion

2.4 Thermal Phase Stability

2.5 Elastic Modulus and Modulus of Rupture

3. Results and Discussion of Task II - Matrix Properties

3.1 Sulfuric Acid

3.2 Sodium Sulfate

3.3 Thermal Expansion

3.4 Thermal Phase Stability

3.5 Elastic Modulus and Modulus of Rupture

3.6 Microstructure and Porosity

4. Conclusions 


\section{List of Tables}

Taste

1 Depth of Sulfuric Acid Reaction $\quad 9$

2 Depth of Sodium Sulfate Reaction 9

3 Young's Modulus $\quad 10$

4 Modulus of Rupture 10

5 Dimensional Stability $\Delta \mathrm{L} / \mathrm{L} \mathrm{ppm}$ to Sodjum Sulfate at $1000^{\circ} \mathrm{C}$ for $24 \mathrm{Hr}$ Cycles Vs. Specimen Cross Sectional Area 11

6 Modulus of Rupture and Elastic Modulus II

7 Matrix Porosity $r$

\section{List of Figures}

Figure

1 Reaction Depth after 80 Hrs of $300^{\circ} \mathrm{C}$ Sulfuric Actd 13

2 Reaction Depth after Six $24 \mathrm{Hr}$ Cycles of Sodium Sulfate at $1000^{\circ} \mathrm{C} \quad 14$

3 Thermal Expansion of 9454 and Materials $1,2,3,4$ after $1000^{\circ} \mathrm{C}-1 \mathrm{Hr} \quad 15$

4 Thermal Expansion of 9454 and Materials $1,2,3,4$ after $1000^{\circ} \mathrm{C}-10 \mathrm{Hrs} \quad 16$

5 Thermal Expansion of 9454 and Materials 1,2,3,4 after 1000 $\mathrm{C}-28 \mathrm{Hrs} \quad 17$

6 Thermal Expansion of 9454 and Materials $I, 2,3,4$ after $1000^{\circ} \mathrm{C}-50$ Hrs 18

7 Thermal Expansion of 9454 and Materials $1,2,3,4$ after $1000^{\circ} \mathrm{C}-75 \mathrm{Hrs} \quad 19$

8 Thermal Expansion of 9454 and Materials $1,2,3,4$ after $1000^{\circ} \mathrm{C}-100$ Hrs 20

9 Dimensional Stability at $1000^{\circ} \mathrm{C}$, Length Change after Exposure 21

10 Dimensional Stability at $1100^{\circ} \mathrm{C}$, Length Change after Exposure 22

11 Matrix Dimensional Stability to $300^{\circ} \mathrm{C}$ Sulfuric Acid - Method $1 \quad 23$

12 Matrix Dimensional Stability to $300^{\circ} \mathrm{C}$ Sulfuric Acid - Method $2 \quad 24$

13 Matrix Dimensional Stability to $1000^{\circ} \mathrm{C}$ Sodtum Sulfate 25

14 Matrix Themal Expansion of 9455 and C-144, C-144-1, C-145 after $1000^{\circ} \mathrm{C}-1 \mathrm{Hr}$

15 Matrix Thermal Expansion of 9455 and C-144, C-144-1, C-145 after $1000^{\circ} \mathrm{C}-10 \mathrm{Hrs}$

16 Matrix Therral Expansion of 9455 and $\mathrm{C}-144, \mathrm{C}-144-1, \mathrm{C}-145$ after $1000^{\circ} \mathrm{C}-28$ Hrs

17 Matrix Thermal Expansion of 9455 and $C=144, C-144-1, C-145$ after $1000^{\circ} \mathrm{C}-50 \mathrm{Hrs}$

18 Matrix Thermal Expansion of 9455 and $C-144, C-144-1, C-145$ after $1000^{\circ} \mathrm{C}-75 \mathrm{Hrs}$

19 Matrix Thermal Expansion of 9455 and $C-144, C-144-1, C-145$ after $1000^{\circ} \mathrm{C}-100 \mathrm{Hrs}$

20 Matrix Dimensional Stability at $1000^{\circ} \mathrm{C}$, Length Change after Exposure 
Figure

21 Matrix Dimensional Stability at $1100^{\circ} \mathrm{C}$, Length Change after Exposure

22 Glass-Ceramic Materials $1,2, \mathrm{C}-144$, and $\mathrm{C}-145$ 


\section{Introduction}

The objective of this program is to develop ceramic materials suitable for use as regenerative heat exchangers for vehicular gas turbines. In Task I of contract MAS3-19733, four materiais were investigated to overcome the chemical attack resulting from the presence of sulfurtc acid and soditu which Timit the life of lithium aluainosilicate (LAS) heat exchange materials. The four glass-ceranic candidate waterials are:

1. A (LMAS) materia] whose major crystalline phase is high quartz soldd solution (SS).

2. A (LAS) material whose major crystalline phase is keatite Ss plus mulitte.

3. CER-VIT ${ }^{(R)}$ material $C-144$, a leached (LAS) material whose najor crystalline phase is silica keatite pius mullite.

4. A (LAS) material whose major crystalline phase is keatite SS.

4-1 CER-VIT ${ }^{(R)}$ material C-145, a silica compositional iteration to material 4 which produced an acceptable lower thermal expansion material.

The major material requirements are low thermai expansion up to $1000^{\circ} \mathrm{C}$, Iong time dimensional stability up to $1000^{\circ} \mathrm{C}$, and the ability to operate at least for short times up to $1100^{\circ} \mathrm{C}$. The four candidate materials are designed to have strength, thermal expansion, thermal dimensional stability and phase stability, and thermal shock resistance comparable to the Corning 9454 solid material, but have improved corrosion resistance with respect to sulfurtc acid and sodium salts. As a result of the materfals testing program on bulk specimens carried out during Task I, all four candidate materials show superior corrosion resistance to both sulfuric acid at $300^{\circ} \mathrm{C}$ and sodium sulfate at $1000^{\circ} \mathrm{C}$ compared to material 9454 . A summary of Task 1 test results is presented in Section 2.

Two of the candidate materials ( 3 and 4-1) were chosen, based on their excellent resistance to sulfuric acid and sodium sulfate, to be fabricated into honeycomb matrix for property testing under Task II. Material 3 has been designated OwensIllinois CER-VIT $(R)$ materlal C-l44 and material 4-1 as CER-VIT(R) material C-145. As a result of the materials testing progran on honeycomb specimens carried out in Task II, CER-VIT(R) materials C-144 and C-145 show superior corrosion resistance to both sulfuric acid and sodfum sulfate compared to Corning matrix LAS 9455 heat exchange material. A summary of Task il test results is presented in Section 3.

\section{Results and Discussion \\ Task I - Bulk Properties}

$\bullet$

As a result of the materials testing program on bulk specimens carried out during Task I of the contract, all four candidate materials show superior corrosion resistance to sulfuric acid at $300^{\circ} \mathrm{C}$ compared to corning materlal 9454 . Figure I

${ }^{(R)}$ CER-VIT is a registered trademark of Owens-IIlnois, Inc. 
shows that the most severe attack on the candidate materials is more than an order of magnitude les\$ than material 9454 . No reaction was observed for material C-144 after six exposure cycles as shown in Table 1.

Results of sodium sulfate corrosion tests as shown in Figure 2 indicate that no reaction was observed for material $\mathrm{C}-\mathrm{T45}$ after $\$ i x$ exposure cycles. The resistance of material C-144 to sodium sulfate is dependent on final thermal treatment as shown in Table 2. After three cycles, no reaction was observed for the C-144 material thermally treated at $1150^{\circ} \mathrm{C}$.

Figures 3 through 8 show the expansion of material 9454 and candidate materials 1,. 2, $\mathrm{C}-144$ and $\mathrm{C}-145$ after exposure to $1000^{\circ} \mathrm{C}$ for $1,10,28,50,75$ and 100 hours, respectively. Three of the candidate materials (2, C-144 and C-145) have the desired thermal expansion from ambient to $1000^{\circ} \mathrm{C}$ of less than $800 \mathrm{ppm} \Delta \mathrm{L} / \mathrm{L}$ as shown in Figure 8 after thermal treatment at $1000^{\circ} \mathrm{C}$ for 100 hours.

Dimensional stability to $1000^{\circ} \mathrm{C}$ and $1100^{\circ} \mathrm{C}$ exposures has been determined as shown in Figures 9 and 10 , respectively, None of the materials is as stable as material 9454; however, materials 2 and $\mathrm{C}$ - 144 have acceptable dimensional stability. Material C-145 (Figure 9) contracts at $1000^{\circ} \mathrm{C}$ and starts to reach equilibrium after $1000^{\circ} \mathrm{C}$ for 75 hours, while thermal treatment at $1100^{\circ} \mathrm{C}$ (Figure 10) causes the material to expand. The effect of heat treatment temperature and resulting dimensional stability at $1000^{\circ} \mathrm{C}$ was investigated in Task II matrix testing and a C-145 material was produced which has good dimensional stabi]lty of less than $\approx 100 \mathrm{ppm} \Delta \mathrm{L} / \mathrm{L}$ change at $1000^{\circ} \mathrm{C}$. Cata of Young's modulus, Poisson's ratto and modulus of rupture are shown in Tables 3 and 4 , respectively. Candidate materials 1,2 and $C-145$ have higher Young's modul 1 and moduli of ruptures than materiai 9454 . Data for material C-144 were not obtained because of the presence of microcracks in bulk specimens $1 / 2 \mathrm{~cm}$ thick which interfere with the sonic resonance test for determining Young's modulus. These microcracks are not present in thin-walled honeycomb matrix of material $\mathrm{C}-144$.

Mercury porosimetry results indicate that materials 1,2 and $C-145$ have a net pore volume of $0.002 \mathrm{cc} / \mathrm{gram}$, while the chemically leached and thermally treated materia] $\mathrm{C}-144$ has a net pore volume of $0.0098 \mathrm{cc} / \mathrm{gram}$. The average pore diameter is 0.006 and $2.10 \mu \mathrm{m}$, respectively.

\subsection{Sulfuric Acid}

Specimens $2.5 \mathrm{~cm}$ diameter and $3.8 \mathrm{~cm}$ long were subjected to $900 \mathrm{milliliters}$ of $96 \%$ sulfuric acid at $300^{\circ} \mathrm{C}$ for six exposure times. The specimens were contatned in KIMAX(R) glass reaction vessels heated by Gas-col heating mantles. The acio is preheated in a separatory funnel and deltyered hot to the reaction vessel which contained one specimen of each material. The acid temperature is controlled to $\pm 1^{\circ} \mathrm{F}$ by a thermocouple suspended into the acid.

SuTfuric acid reacts with LAS materials by exchanging hydrogen ions for lithium. This ion exchange reaction produces cracking in the microstructure if large specimen cross sections are involved. The depth of lon exchange is measured by optical microscopy. Figure 1 shows the reaction depth into the materials after 80 hours of $300^{\circ} \mathrm{C}$ sulfuric acid exposure. 
Tabie 1 gives the reaction depth in millimeters vs. exposure time in sulfurtc acid. The average reaction depth for three specimens is reported.

Further characterization of materia] C-144 indicates that the material has no weight loss after acid exposure. A change in specimen length of $13 \mathrm{ppm} \Delta \mathrm{L} / \mathrm{L}$ was measured after 80 hours of acid exposure at $300^{\circ} \mathrm{C}$.

\subsection{Sodjum Sulfate}

In situ X-ray diffraction of sodium sulfate reacted specimen surfaces have been evaluated to determine the depth of ion exchange of Ha for Li. Sodjum expands the crystal lattice of LAS keatite and a marked change in crystal "D" spacing occurs in the ion exchanged surface layer. The depth of ton exchange on bulk specintens is obtained by mechanically grinding off the sodium sulfate exposed surface until no change in crystal " $D$ " spacings is observed as compared to the original unreacted specimen surface.

The test consists of covering a specimen surface area of $3.4 \mathrm{~cm}$ with 0.0170 grams of anhydrous sodium sulfate and heating the coated specinien at $1000^{\circ} \mathrm{C}$ for 24 hours. Six exposure cycles are measured to determine the reaction depth. Material is ground off in 10 to wol intervals depending on the material and the extent of the surface reaction.

Figure 2 shows the reaction depth into the materials after six exposure cycles of sodium sulfate.

Table 2 shows the reaction depth for the materials after each 24 hour cycle. Corning material 9454 and material 2 (both LAS keatite materials) undergo an ion exchange of Na for $\mathrm{Li}$ when exposed to sodi un sulfate as a marked change in crystal " 0 " spacing is observed by $X$-ray diffraction. Hateriat 1 , with a "stuffed" high quartz solid solution crystalline phase, does not show any change in crysta] " $D$ " spacings but the surface is altered by secondary crystallization fornting (LAS) keatite $\$ . S$. and amorphous material with less intense high quartz 5.5 . crystalm line peaks.

The resistance of material $\mathrm{C}-144$ to sodium sulfate is dependent on final thermal treatment after acid leaching the 11thia from the keatite structure as shown in Table 2. The reacted surface contains $\mathrm{SiO}_{2}$ cristobalite; also, amorphous material is sometimes found.

Material $\mathrm{C}-145$ looks very pronising with respect to sodium sulfate resistance in that no reaction has been detected for the $s j x$ exposures to sodium sulfate. Further testing of this material in sheets 0.7 to $1 \mathrm{~mm}$ in thickness with sodium $5 u$ lfate applited to one surface indicates no warpage after $1000^{\circ} \mathrm{C}$ for 64 hours. Exposure cycles at 24 hour intervals indicate that warpage does occur after the third exposure. This is beljeved due to a bujid-up of fused salt on the materials surface which is measured after each application of sodium sulfate.

\subsection{Thermal Expansion}

The thermal expansion $\Delta \mathrm{L} / \mathrm{L}$ in ppm over the temperature range of ambient to $1000^{\circ} \mathrm{C}$ for the candidate materials and 9454 is shown in figures 3 through 8 . The standard deviation is $30 \mathrm{ppm} A L / L$ for the three specimens measured. The thermal expansion specimens are cycled between ambient and $1000^{\circ} \mathrm{C}$ according to the following schedule: 
1. ten cycles with a 1 hour hold at $1000^{\circ} \mathrm{C}$

2. three cycles with a 6 hour hold at $1000^{\circ} \mathrm{C}$

3. one cycle with a 22 hour hold at $1000^{\circ} \mathrm{C}$

4. two cycles with a 25 hour hold at $1000^{\circ} \mathrm{C}$

Thermat expansion was measured after exposure times at $1000^{\circ} \mathrm{C}$ for $1,10,28,50$, 75 and 100 hours. The specimen length was measured before and after each thermal exposure and thermal expansion test. Figure 9 shows the specimen length change $(A L / L \mathrm{ppm})$ after themal exposure to $1000^{\circ} \mathrm{C}$.

\subsection{Thermal Phase Stability}

Thermal phase stability at $1100^{\circ} \mathrm{C}$ for all materials has been analyzed by $X$-ray diffraction. Corning material 9454 and materials $1,2, C-144$ and $\mathrm{C}-145$ are stable for the 10 exposure cycles (ambient to $1100^{\circ} \mathrm{C}$ with a $t$ hour hold for each cycle) with no change in crystal lattice parameter detected. Material 4 is not stable at $1100^{\circ} \mathrm{C}$ and contains larger amount of cristobalite in the range of 5-10 wt. with increasing thermal exposure.

Dimenstonal stability at $1100^{\circ} \mathrm{C}$ is shown in Figure 10 for Corning material 9454 and the candidate materials. The average dimensional change $\Delta \mathrm{L} / \mathrm{L} \mathrm{pPm}$ at $1100^{\circ} \mathrm{C}$ for three specimens is reported. Dimensional instability of matertal 4 can be attributed to the presence of cristobalite.

\subsection{Elastic Modulus and Modulus of Rupture}

No values were obtained for material $\mathrm{C}-144$ because of the gresence of some microcracks in the bulk spectmens which interfere with the sonic resonance test. These microcracks are not present in thin-walled honeycomb matrix.

Vaiues for Young's modulus and Polsson's ratios are shown in Table 3 for the other candidate materfals.

Three specimens of each candidate material having dimensions of $11.4 \times 1.9 \times 1.3$ car were broken in four point flexure with the $11.4 \times 1.9 \mathrm{~cm}$ surface being the tensile surface. The outer $\mathrm{knife}$ edge span was $8.9 \mathrm{~cm}$ and the inside span was $1.9 \mathrm{~cm}$. Table 4 shows the modulus of rupture values abtained. All fractures started between the $1.9 \mathrm{~cm}$ span and were inftfated in the plane of the specimen surface rather than at the edge.

\section{Results and Discussion \\ Task II - Matrix Properties}

Two of the candidate materials (C-144 and C-145) were chosen, based on their excellent resistance to sulfuric acid and sodium sulfate, to be fabricated into honeycomb matrix for property testing under Task. II.

As a result of the materials testing program on honeycomb specimens carried out in Task II, CER-VIT $(R)$ honeycomb $C-144$ and C-145 show superior corrosion resistance to sulfuric acid and sodium sulfate compared to corning honeycomb 9455 . Figure 11 shows that materjal $\mathrm{C}-144$ is two orders of magnitude better than 9455 in dimensiona] 
stabtitty to sulfuric acid at $300^{\circ} \mathrm{C}$. Material $\mathrm{C}-145$ is twice as good as 9455 in dfmensional stability to sulfuric acid after three exposure cycles and is about equal to 9455 after six cycles.

Results from sodium sulfate corrosion tests, as shown in Figure 13 and tabulated in Table 5, indlcate that material $\mathrm{C}-144$ is one order of magnitude better in stability to sodium $\$$ ulfate at $1000^{\circ} \mathrm{C}$ after $\mathbf{s}\{\mathrm{x}$ exposure cycles than material 9455. Matertal C- 145 is one order of magnitude better than 9455 after three cycles and about four times better after six exposure cycles.

Figures 14 through 19 show the expansion of materials 9455, C-144, C-144-1 and $\mathrm{C}-145$ after exposure to $1000^{\circ} \mathrm{C}$ for $1,10,28,50,75$ and 1000 hours, respectively. Both materials C-344 and C-145 have less than $600 \mathrm{ppm} \Delta \mathrm{L} / \mathrm{L}$ therma] expansion from ambient to $1000^{\circ} \mathrm{C}$ for the indicated times. Depending on thermat treatment, materja] C-144 can have either a negative expansion of $-550 \mathrm{AL} / \mathrm{L}$ fron ambient to $1000^{\circ} \mathrm{C}$ or a near-zero expansion $(\mathrm{C}-144-1)$ as indicated in Figures 14 through 19 , However, $\mathrm{C}-144$ as a negative expansion material has better dimensional stability to both sulfuric acid and sodium sulfate. Testing in this area will continue in Task $V$ by comparing the corroston resistance of $C-144$ with the Corning 9460 AS heat exchange materiat.

Otmensional stability of the candidate naterials to $1000^{\circ} \mathrm{C}$ and $1100^{\circ} \mathrm{C}$ is shown In Figures 20 and 21 , respective $7 y$. Materials $9455, \mathrm{C}-144, \mathrm{C}-144-1$ and $\mathrm{C}-145$ all have good dimensiona? stability of less than $\omega 100 \mathrm{ppm} \mathrm{AL} / \mathrm{L}$ at $1000^{\circ} \mathrm{C}$ for the indicated times, while materials 9455 and $C-145$ have better dimensional stability at $1100^{\circ} \mathrm{C}$ than material $\mathrm{C}-144$ which contracts about $300 \mathrm{pp}$ il $\Delta \mathrm{L} / \mathrm{L}$ after 10 hours while materials 9455 and $\mathrm{C}-145$ expand less than $40 \mathrm{ppm} \Delta \mathrm{L} / \mathrm{L}$.

Elastic modulus, modulus of rupture, and marcury porosimetry results are shown in Tables 6 and 7 , respectively. Thin wall $\mathrm{C}-144$ and $\mathrm{C}-145$ matrixes have tensile strengths of $365 \mathrm{psi}$ with less than $5 \%$ wall porosity.

\subsection{Sutufuric Acid}

Honeyconb specimens were immersed in $1 \%$ sulfuric acid, evacuated to remove air from the passages, and removed from the acid after 2 hours. Excess acid was allowed to drain from the honeycomb by gravity before inserting then into a furnace at $300^{\circ} \mathrm{C}$ for 2 hours to complete one cycle. Figure 11 shows the dimensional changes $\Delta L / L$ ppm after six exposure cycles.

Figure 12 shows the effect of amaller acid concentration in that excess acid was allowed to drain from the honeycomb by gravity and then the matrix was shook twice which removed more acid. Materiai $c-145$ contracts with the weaker acid concentration, but expands by cracking with the more concentrated acid as a result of the $\mathrm{H}^{+}$for $\mathrm{Lj}^{+}$ion exchange.

\subsection{Sodiun Sulfate}

Minus 200 mesh reagent grade anhydrous sodium sulfate was dusted through the honeycomb matrix passages of materials 9455 and $C-145$ as evenly as possible until a specimen weight gain of $1 / 4 \%$ was measured. The specimens were exposed to $1000^{\circ} \mathrm{C}$ for 24 hours to complete onè cycle. Results for six cycles are shown in Figure 13 and tabulated in Table. 5. Material $\mathrm{C}-144$ is two orders of magnjtude better 
in dimensional stability to sodiun sulfate than 9455 after six cycles while material C-145 is an order of magnitude better than 9455 after three cycles and about four times better after $\$$ ix exposure cycles.

Comparison of ford data and Owens-Ilijnois data vs. specimen cross sectiona] area as shown in Table 5 indicates a large amount of variability in dimensional change with exposure cycle. Dusting the matrix does not give uniform distribution of sodium sulfate dowm the tube interior with majority of the sodium sulfate remaining near the specimens' ends producing Targe dimensional changes in honeycomb 9455 .

\section{3 Therma] Expans,ion}

The thermal expansion $\Delta \mathrm{L} / \mathrm{L}$ in $\mathrm{ppm}$ over the temperature range of aubient to $1000^{\circ} \mathrm{C}$ for materials $\mathrm{C}-144, \mathrm{C}-144-\mathrm{l}, \mathrm{C}-145$, and 9455 is shown in Figures 14 through 19 after exposure to $1000^{\circ} \mathrm{C}$ for $1,10,28,50,75$ and 100 hours, respectively. The standard deviation is $50 \mathrm{ppm} \mathrm{AL} / \mathrm{L}$ for the three specimens measured.

The thermal expansion specimens were cycled between antient and $1000^{\circ} \mathrm{C}$ according to the following schedule:

i. ten cycles with 1 hour hold at $1000^{\circ} \mathrm{C}$

2. three cycles with a 6 hour hold at $1000^{\circ} \mathrm{C}$

3. one cycle with a 22 hour hold at $1000^{\circ} \mathrm{C}$

4. two cycles with a 25 hour hold at $1000^{\circ} \mathrm{C}$

Thermal expansion was measured after exposure times at $1000^{\circ} \mathrm{C}$ for $1,10,28,50$, 75 and 100 hours. The specimen length is measured before and after each thermal exposure. Figure 20 shows the specjimen length change ( $\mathrm{LL} / \mathrm{L} \mathrm{ppm}$ ) after thermal exposure.

\subsection{Thermal Phase Stability}

Thermal phase stabitity at $1100^{\circ} \mathrm{C}$ for $9455, \mathrm{C}-144$ and $\mathrm{C}-145$ has been analyzed by $X$-ray diffraction. Corning honeycomb $9455, C-144$ and $C-145$ are stable for the 10 exposure cycles, ambient to $1100^{\circ} \mathrm{C}$ with a one hour hold for each cycle. Dimensionat stability at $1100^{\circ} \mathrm{C}$ is show in Figure 21 for materlals $9455, \mathrm{C}-144$ and $\mathrm{C}-145$.

\subsection{Elastic Modulus and Modulus of Rupture}

Modulus of rupture values shown in Table 6 were obtained using four-point. flexure. The outer kntfe edge span was $8.9 \mathrm{cms}$ and the Inner span was T.9 chl. Specimen dimenstons were $11.4 \times 1.9 \times 1.3 \mathrm{cms}$ with the $11.4 \times 1.9$ cill surface as the tensile surface. Stress rates were $700 \times \mathrm{Pa}$ per min. for tangenttal 9455 matrix and $200 \mathrm{KPa}$ per min. for radial 9455 matrix and isotropic matrixes C-144 and $C-145$. Matrixes $C-144$ and $C-145$ have a high open frontal area of $85 \%$ conl pared to 9455 matrix which has $65 \%$ open frontaj area. The lower strength values of approximately $450 \mathrm{KPa}$ for $\mathrm{C}-144$ and $\mathrm{C}-145$ compared to 9455 matrix strengths of 
$1790 \mathrm{KPa}$ (radial) and $4830 \mathrm{KPa}$ (tangential) is attributed to the thinner 50 uin matrix wall thickness of $\mathrm{C}-144$ and $\mathrm{C}-145$ compared to the 130 to 305 un wall of matrix 9455.

Elastic modulus values shown in Table 6 were obtained using the sonic resonance technique according to ASTM Standard C623-69T. These are tentative values since we have obtained the same published value for 9455 tangentlal specimens but are one order in magnitude higher for 9455 radial specimens. This dfscrepancy is due to matrix wall and void configuration which effect the ability to determine the resonance frequency. Strain gages will be used in future testing to determine the elastic modulus.

\subsection{Microstructure and Porosity}

Electron micrographs of solid materiais $]$ and 2 and matrix materials $[-144$ and C-145 are shown in Figure 22. Materia]s 2, C-144 and C-145 all have grain sizes less than 1 um. Material 1 has a 2-1/2 um grain size.

Mercury porosimetry results for matrix materials C-144, C-145, and 9455 are shown in Table 7.

Matrfx $\mathrm{C}-145$ has a ca]culated wall porosity of $5 \%$; however, matrix $C-145$ has a near hexagonal cross section but at tube interstices a 50 um dia. open area exists where the two glass tube walls did not bloat together. This open area may account for the 52 a average dia. pore reported from mercury porosimetry. Because this open interstitial area influences the displacement density, a higher wall porosity is calculated than what is actually present. Matrix C-144 has a bimodal distribution of voids, 20 un average dia. voids which may be because of the interstitial area between tubes and 0.01 um average dia. voids in the tube walls as a resutt of leaching lithium from the material. The wall porosity wil] be investigated further for matrixes $\mathrm{C}-144$ and $[-145$ after stuffing material has been added to the glass tube bloating process or other techniques are used to eliminate the open interstitia] area. The interstitial area is not desirable from a seal bar wear standpoint because a single wall rather than a double wall thickness is present.

\section{Conclusions}

This investigation evaluated four glas\$-ceramic materials suitable for use as gas turbine heat exchangers. The purpose of the program was to develop improved corrosion resistant materials less susceptible to attack by sulfuric acid and sodium salts. Comparative tests of the new improved aterials fabricated as solid and honeycomb matrix were made with lst generation lithium aluminosilicate (LAS) Cornting solid 9454: and heat exchanger matrix 9455.

Two of the glass-ceramic materials, C-144 and C-145, have superior durability towards sulfuric acid and sodium sulfate compared to Corning materials 9454 and 9455. Material C-144 is a leached LAS material whose major crystalline phase is silica keatite plus mullite. Material C-145 is composed of LAS keatite solid solution. 
1. Material $\mathrm{C}-144$ is two orders of magnitude better in dimensionat stability to sulfuric acid at $300^{\circ} \mathrm{C}$, and one order of magnj tude better in stability to sodium sulfate at $1000^{\circ} \mathrm{C}$ compared to material 9455 .

2. Material c-145 is initially two times better in stability to sulfuric acid at $300^{\circ} \mathrm{C}$ and about one order of magnitude better in stability to sodfum sulfate at $1000^{\circ} \mathrm{C}$ compared to material 9455 .

3. Materials C-144 and C-145 are either better than or comparable to material 9455 in physical properties. Materials C-144 and C-145 have less than $300 \mathrm{ppm} A L / L$ thermal expansion from ambient to $1000^{\circ} \mathrm{C}$, good dimensional stability of less than $2100 \mathrm{ppm} \Delta \mathrm{L} / \mathrm{L}$ change in length after exposure to $1000^{\circ} \mathrm{C}$ for 100 hours and acceptable dimensional stability to short exposure times at $1100^{\circ} \mathrm{C}$. Materlal C-145 expands less than $40 \mathrm{ppm} \Delta \mathrm{L} / \mathrm{L}$ after $1100^{\circ} \mathrm{C}$ for 10 hours whtle material $\mathrm{C}-144$ contracts about $300 \mathrm{ppm}$ $\Delta L / L$. Material 9455 has a $500 \mathrm{ppm} \mathrm{AL} / \mathrm{L}$ thermal expansion from ambient to $1000^{\circ} \mathrm{C}$, good dimensional stability of less than $\approx 100 \mathrm{ppm}$ change in length after $1000^{\circ} \mathrm{C}$ for 100 hours, and has adequate dimensional stability at $1100^{\circ} \mathrm{C}$ expanding less than $40 \mathrm{ppm} \Delta \mathrm{L} / \mathrm{L}$ change in length after t0 hours.

4. The glass-ceramic fabrication process of $\mathrm{C}-144$ and $\mathrm{C}-145$ produced a hexagonal honeycomb matrix with a very thin wall thickmess of $50 \mu \mathrm{mm}$, a very high open frontal area of $85 \%$, and a wall porosity of less than 5\%. Because of the thin walls and high open frontal area, matrix honeycomb C-144 and C-145 have a lower tensile strength perpendicular to the open passages than material 9455. Honeycomb C-144 and C-145 have fsotrapic structures with tensile strengths of $450 \mathrm{KPa}$ compared to the anisotropic structure of 9455 matrix which has a tensile strength of $1800 \mathrm{KPa}$ in the radial direction and $4800 \mathrm{KPa}$ in the tangential direction. The wall thickness of the 9455 matrix varies between 130 to $305 \mu \mathrm{m}$. 
Table 1 - Depth of Sulfuric Acid Reaction (in millimeters)

\begin{tabular}{|c|c|c|c|c|c|c|}
\hline $\begin{array}{l}\mathrm{H}_{2} \mathrm{SO}_{4} \text { at } \\
300^{\circ} \mathrm{C} \text { for }\end{array}$ & $\underline{9454}$ & 1 & 2 & $\mathrm{c}-1,44$ & 4 & $\mathrm{c}-145$ \\
\hline 6 hours & 0.995 & 0.147 & 0.035 & $\begin{array}{c}\text { none } \\
\text { detected }\end{array}$ & 0.227 & 0.083 \\
\hline 16 hours & 2.13 & 0.233 & 0.089 & " & 0.306 & 0.164 \\
\hline 32 hours & 3.38 & 0.270 & 0.161 & $"$ & 0.390 & 0.215 \\
\hline 48 hours & 4.77 & 0.292 & 0.198 & $"$ & 0.443 & 0.224 \\
\hline 64 hours & 5.27 & 0.323 & 0.205 & $"$ & 0.482 & 0.265 \\
\hline 80 hours & 6.40 & 0.420 & 0.237 & $"$ & 0.544 & 0.310 \\
\hline
\end{tabular}

Table 2 - Depth of Sodium Sulfate Reaction ( $\mu x$ )

\begin{tabular}{|c|c|c|c|c|c|c|c|c|c|}
\hline $\begin{array}{l}\mathrm{Na}_{2} \mathrm{SO}_{4} \text { at } \\
1000^{\circ} \mathrm{C} \text { for } \\
24 \text { hours } \\
\end{array}$ & 9454 & 1 & $\underline{2}$ & Heat Tre & $\begin{array}{r}\text { C-144 } \\
\text { atment T } \\
1200=\end{array}$ & $\begin{array}{l}4 \\
\frac{T e n p e r s}{1 h r}\end{array}$ & ature $f^{\circ}$ & c) & $c-145$ \\
\hline \multicolumn{2}{|c|}{ Crístobalite* } & & & 0 & 0 & 10 & 5 & 10 & \\
\hline I Cycie & 45 & 20 & 5 & 0 & $0 \quad---$ & -- & 10 & --- & $N^{* *}$ \\
\hline 2 Cycles & 100 & 90 & 30 & 0 & 150 & -- & & 400 & $\mathrm{H}$ \\
\hline 3 Cycles & 155 & 100 & 45 & 0 & 550 & 200 & & 900 & N \\
\hline 4 Cycles & 200 & 100 & 65 & & & 750 & & & $N$ \\
\hline 5 cycles & 205 & 135 & 90 & & & 1000 & & & $\mathbf{N}$ \\
\hline 6 cycles & 230 & 205 & 130 & & & $\star \star \star$ & & & $\mathbf{N}$ \\
\hline
\end{tabular}


Iable 3 - Young's Modulus

\begin{tabular}{|c|c|c|c|}
\hline & $\begin{array}{r}\text { Young's } \\
\mathrm{KPa} \times 10^{-6}\end{array}$ & $\begin{array}{l}\text { Modulus } \\
\left(\text { Psi } \times 10^{-5}\right)\end{array}$ & $\begin{array}{c}\text { Poisson's } \\
\text { Ratio } \\
\end{array}$ \\
\hline Material 1 & 91.57 & $(13.28)$ & 0.23 \\
\hline Material 2 & 76.12 & (11.04) & 0.25 \\
\hline Material C-144 & $m$ & & - \\
\hline Material 4 & 77.43 & (11.23) & 0.23 \\
\hline Material C-145 & 80.95 & (11.74) & 0.26 \\
\hline Materia] 9454 & 73.64 & $(10.68)$ & 0.28 \\
\hline
\end{tabular}

Table 4 - Modulus of Rupture

\begin{tabular}{|c|c|c|c|c|c|c|c|}
\hline \multirow[b]{2}{*}{ Material } & \multicolumn{2}{|c|}{$\begin{array}{l}\text { Hodutus of Rupture } \\
\text { Strength }\end{array}$} & \multicolumn{2}{|c|}{ Std. Deviation } & \multirow{2}{*}{$\begin{array}{l}\text { Time to Failure } \\
\text { (sec.) }\end{array}$} & \multicolumn{2}{|c|}{ Load } \\
\hline & م & $\frac{(P S 1)}{(1)}$ & $\mathrm{KPa}$ & (Ps.1) & & kgs. & (1bs.) \\
\hline 9454 & 69,600 & $(10,100)$ & 5,500 & $(800)$ & 27 & 204 & $(450)$ \\
\hline 1 & 93,800 & $(13,600)$ & 5,500 & $(8 \infty 0)$ & 31 & 259 & $(570)$ \\
\hline 2 & 90,300 & $(13,100)$ & 6,900 & $(1000)$ & 27 & 247 & (545) \\
\hline$C-144$ & -- & -- & - & -- & -- & $=$ & -- \\
\hline 4 & 38,600 & $(5,600)$ & 11,700 & $(1700)$ & 16 & 120 & $(265)$ \\
\hline$C-145$ & 104,100 & $(15,100)$ & 8,300 & $(1200)$ & 31 & 308 & $(680)$ \\
\hline
\end{tabular}


Table 5 - Dimensional Stability $\Delta \mathrm{L} / \mathrm{L} \mathrm{ppm}$ to Sodium Sulfate at $1000^{\circ} \mathrm{C}$ for $24 \mathrm{Hr}$. Cycles Vs. Specimen Cross Sectional Area

\begin{tabular}{|c|c|c|c|c|c|}
\hline \multirow{2}{*}{$\begin{array}{l}\text { Specimen } \\
\text { Length cal } \\
\text { Cross Sectional } \\
\text { Area } \mathrm{cm}^{2}\end{array}$} & 9455 & $\begin{array}{l}9455 \\
6.9\end{array}$ & $\begin{array}{l}9455 \\
6.9\end{array}$ & $\begin{array}{l}c-144 \\
6.9\end{array}$ & $\begin{array}{l}c-145 \\
6.9\end{array}$ \\
\hline & \multirow[t]{2}{*}{ Ford Data* } & \multirow[t]{2}{*}{1.6} & \multirow[t]{2}{*}{4.5} & \multirow[t]{2}{*}{4.8} & \multirow[t]{2}{*}{$\underline{4.8}$} \\
\hline Cycle & & & & & \\
\hline 1 & 175 & 2070 & 250 & -95 & 30 \\
\hline 2 & 400 & 2930 & 1800 & -170 & 180 \\
\hline 3 & 700 & -- & 2200 & -135 & 390 \\
\hline 4 & 1250 & $=$ & 2550 & -170 & 490 \\
\hline 5 & 1575 & -- & 2830 & -195 & 625 \\
\hline 6 & -- & -- & 2990 & -200 & 750 \\
\hline
\end{tabular}

*C00-2630-15, Ford Progress Report, Apri] 1976, "Automotive Gas Turbine Ceranic Regenerator Design and Reliabijity Program."

Table 6 - Modulus of Rupture and Elastic Modulus

$\underline{9455}$

\begin{tabular}{|c|c|c|c|c|c|c|}
\hline & \multicolumn{2}{|c|}{ Young's Modulus $\times 10^{-6}$} & \multirow{2}{*}{\multicolumn{2}{|c|}{$\begin{array}{c}\begin{array}{c}\text { Matrix WaT1 } \\
\text { Thickness }\end{array} \\
\text { (mitis) }\end{array}$}} & \multirow{2}{*}{$\begin{array}{c}\text { Open } \\
\text { Frontat } \\
\text { Area } \\
\approx \\
\end{array}$} \\
\hline $\mathrm{KPa}$ & $\left(P_{s i}\right)$ & Kpa & (Psi) & & & \\
\hline
\end{tabular}

Solid

$$
68,950 \quad(10,000) \quad 73.64
$$

Matrix

Radial $\quad 1,600 \quad(260) \quad 7.6$

Tangential

4,800

(700) $\quad 13.8$

C-144

Salid

Matrix

$\begin{array}{lll}-- & -- & -- \\ 410 & (60) & 1.0\end{array}$

(0.15)

50

(2)

85

C-145

Solid

latrix
104,100
480

(11.74)

(0.18)

50

(2)

85 
Table. 7 - Matrix Porosity

\begin{tabular}{|c|c|c|c|c|c|}
\hline Matrix & $\begin{array}{l}\text { Het Pore Vol. } \\
(\mathrm{cc} / \mathrm{g})\end{array}$ & $\begin{array}{c}\text { Aveg. Pore Dia. } \\
\text { (ه⿴囗十) }\end{array}$ & Butk & $\begin{array}{l}\text { Density (q⿴囗cc) } \\
\text { Displacement }\end{array}$ & Skeletal \\
\hline 9455 & 0.03362 & 7.4 & .74 & $2.08 *$ & $2.28 *$ \\
\hline$C-144$ & 0.02898 & 0.01 & .40 & -- & $=$ \\
\hline C-145 & 0.02188 & 52 & .37 & 2.52 & 2.39 \\
\hline
\end{tabular}


SLLFURIC ACID 80 hr $300^{\circ} \mathrm{C}$

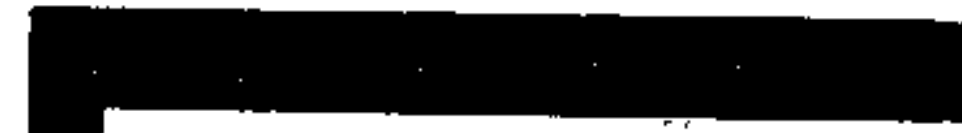

CORNING 9454 LAS

LMAS QUARTZ SS (I)

KEATITE SS + MULLITE (2)

$0 \mathrm{~mm}$ LEACHED LAS C-144

KEATITE SS (4)

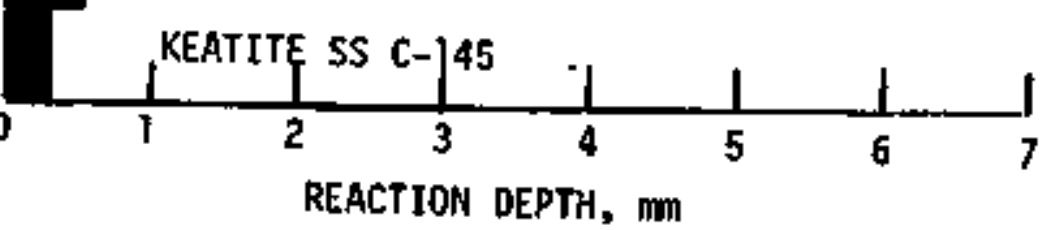

Figure 1 - Reaction Depth after 80 Hrs. of $300^{\circ} \mathrm{C}$ Sulfuric Acid 
SODIUN SULFATE SIX $24 \mathrm{hr}$ CYCLES AT $1000^{\circ} \mathrm{C}$

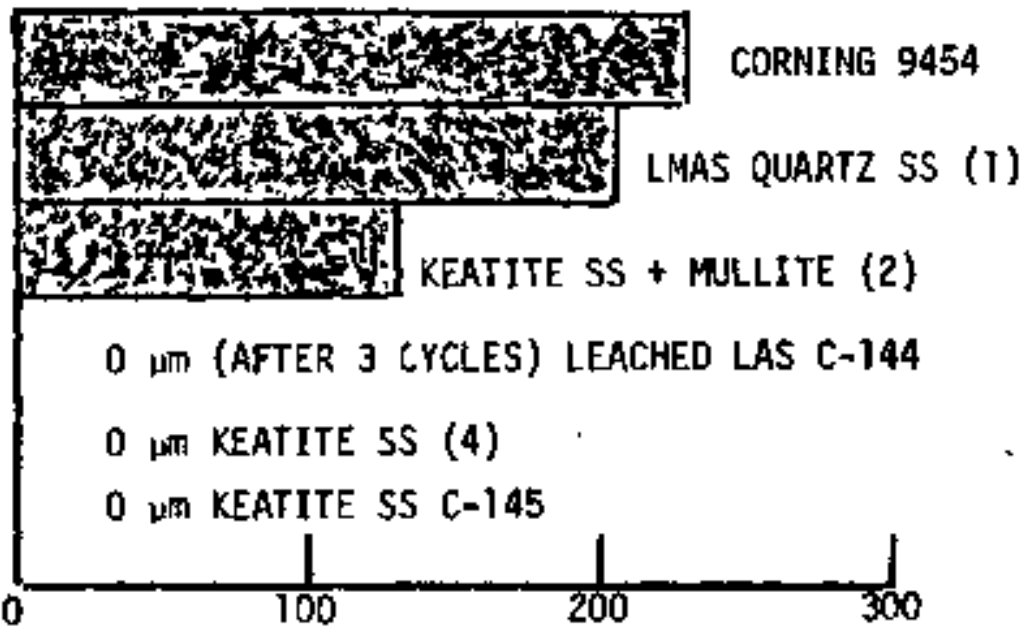

Figure 2 - Reaction Depth After Six $24 \mathrm{Hr}$ Cycles of Sodium Sulfate at $1000^{\circ} \mathrm{C}$ 


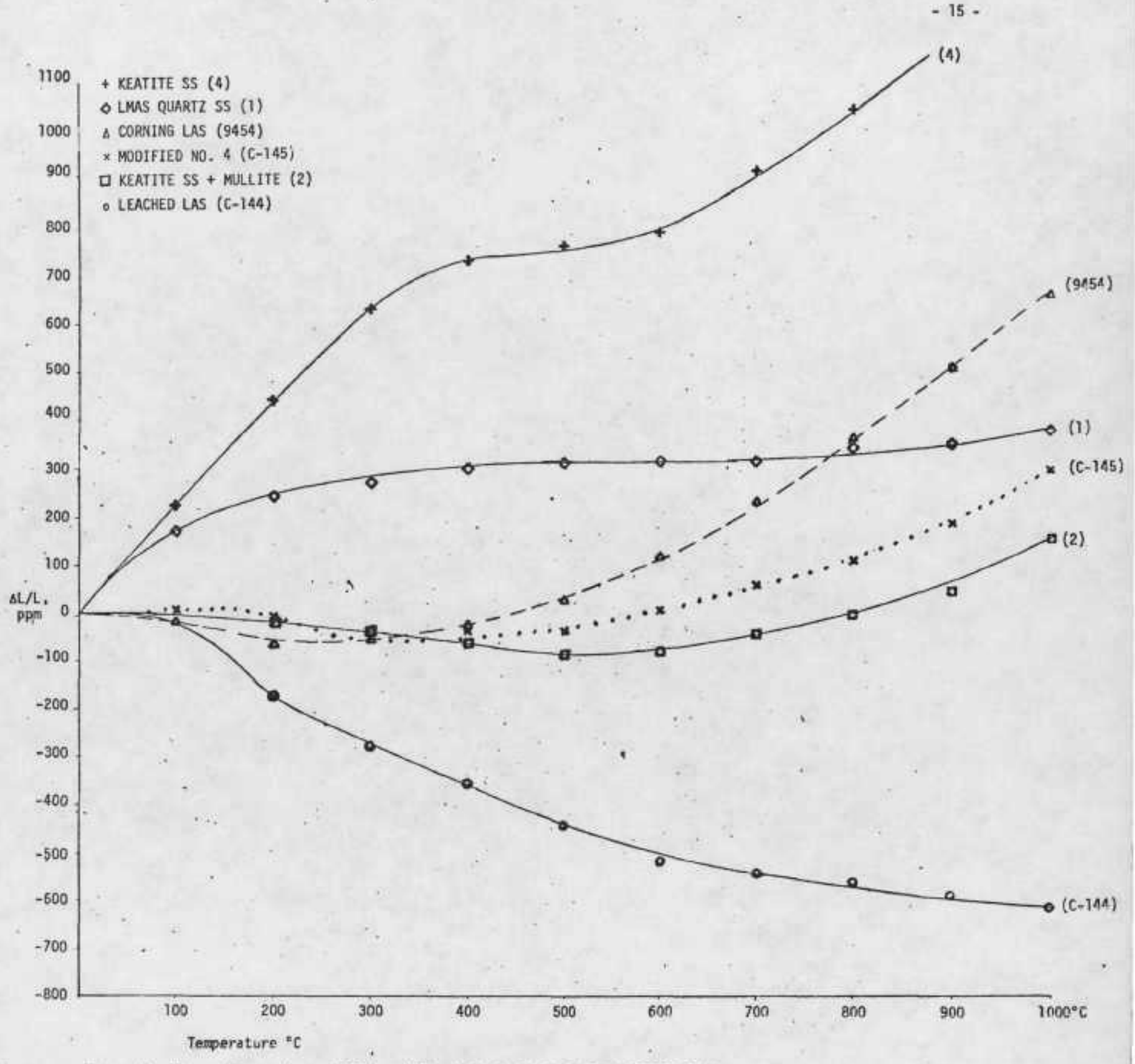

Figure 3 - Therma 1 Expansion of 9454 and Materials $1,2,3,4$ After $1000^{\circ} \mathrm{C}-1 \mathrm{Hr}$ 


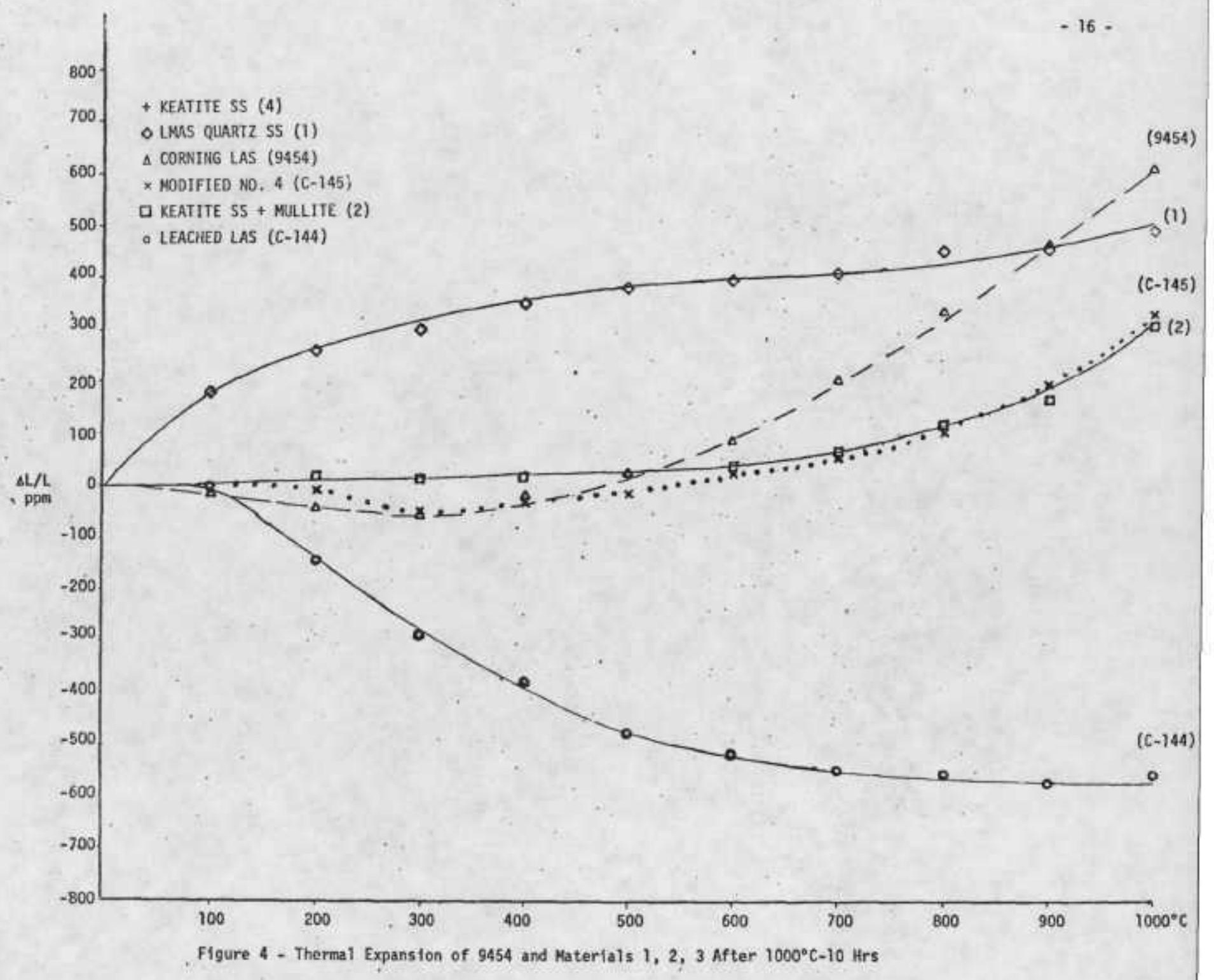




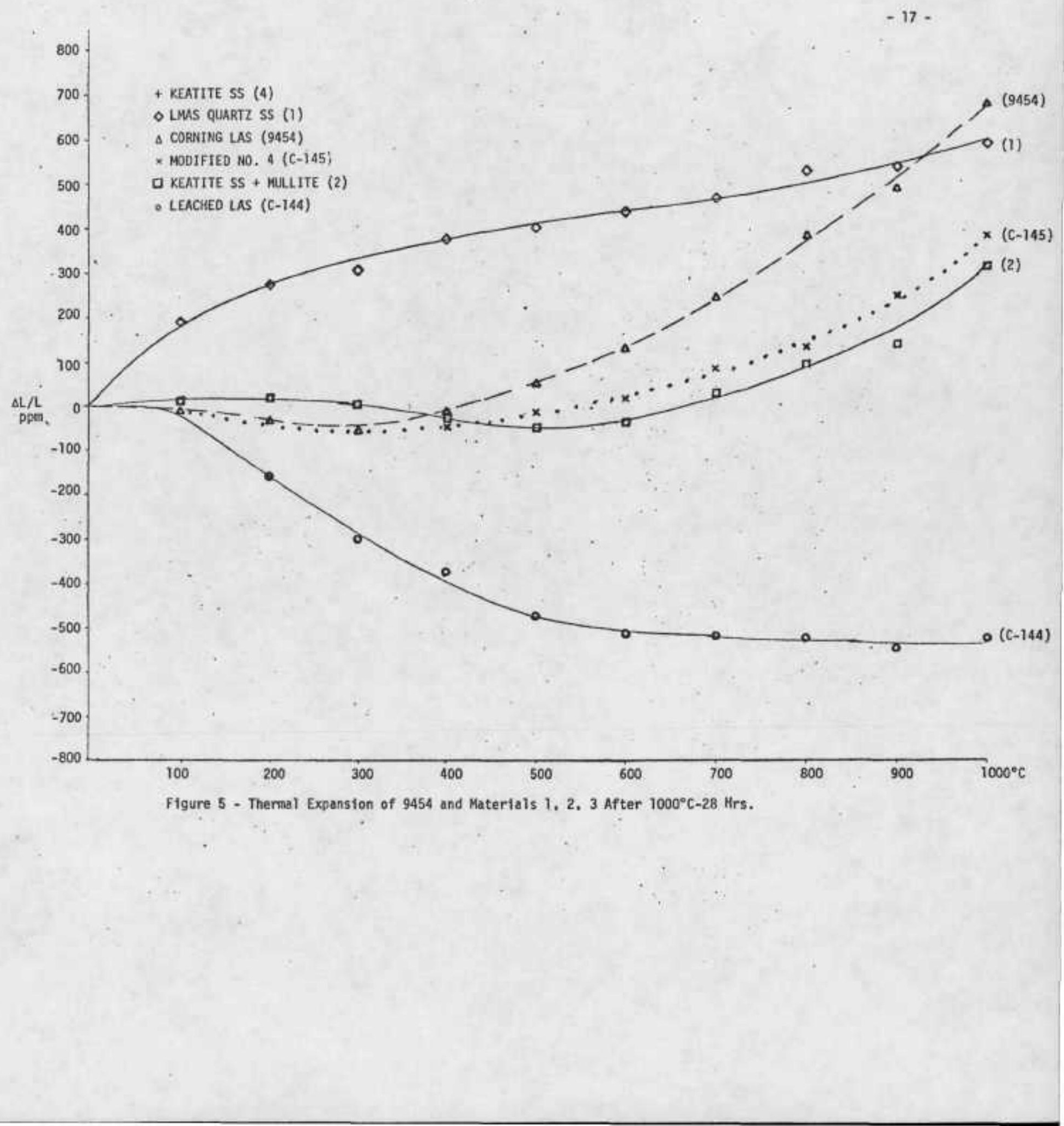


$-18=$

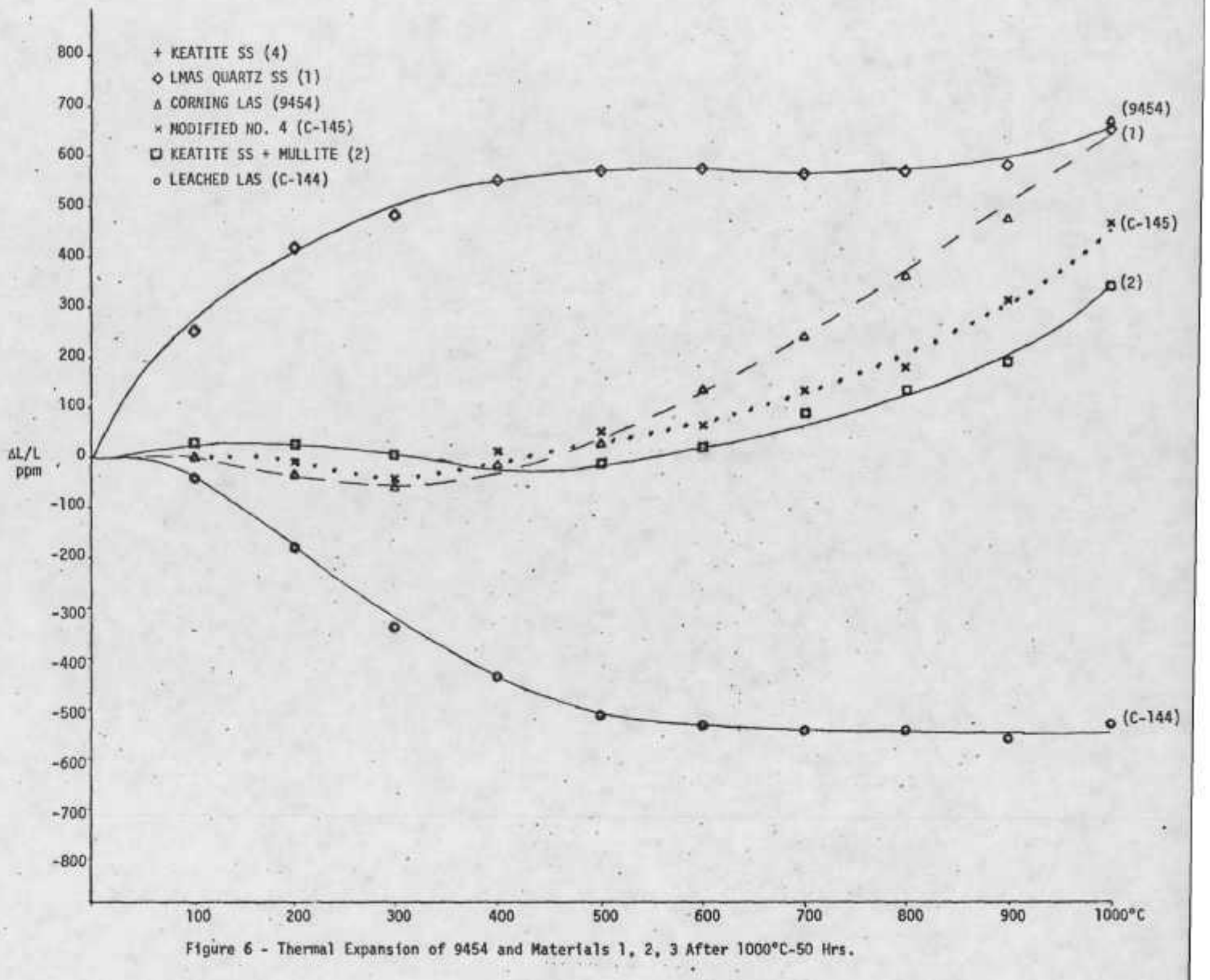


$-19$.

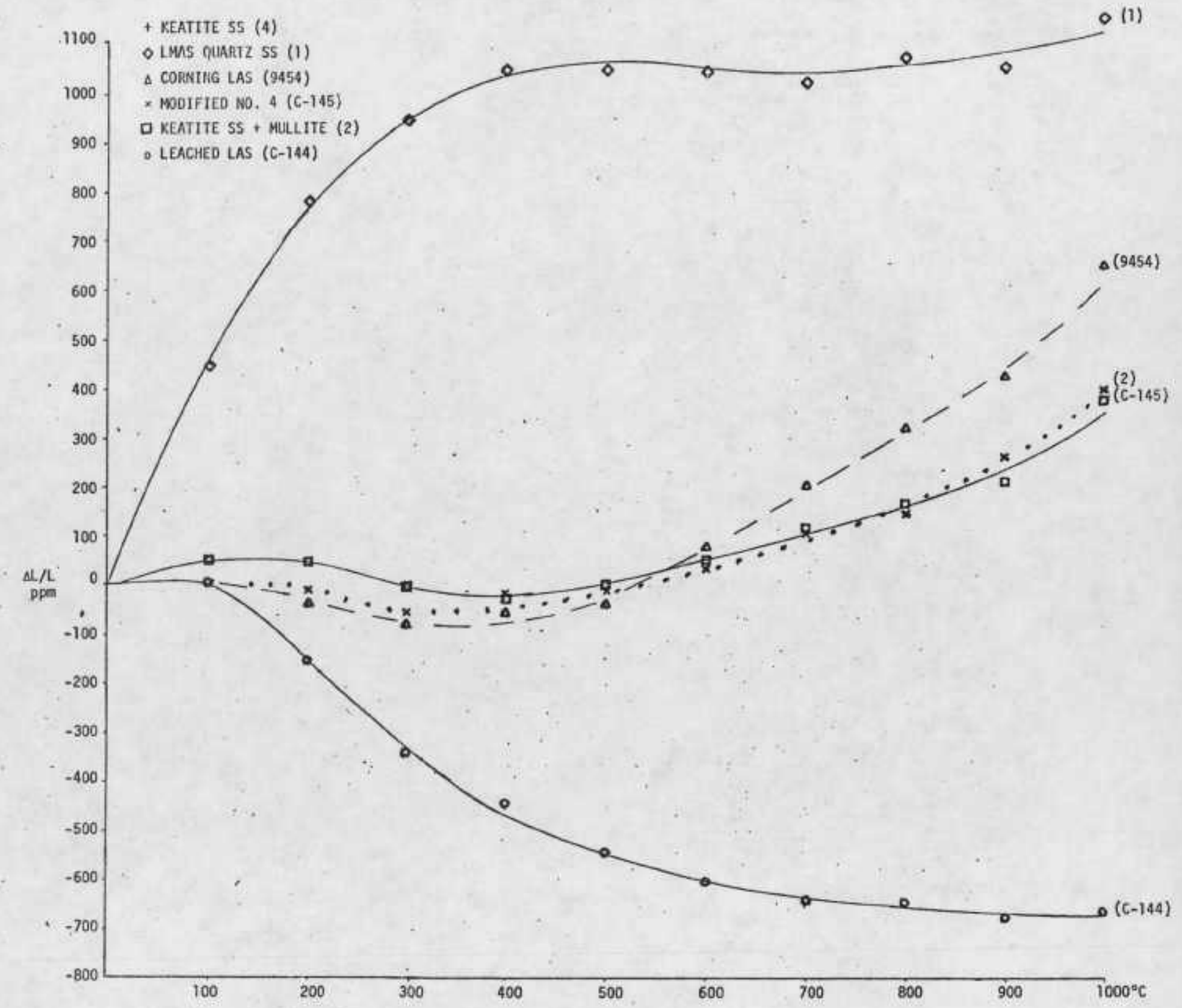

Figure 7 - Thermal Expansion of 9454 and Matertals 1, 2, 3 After $1000^{\circ} \mathrm{C}-75$ Hrs 


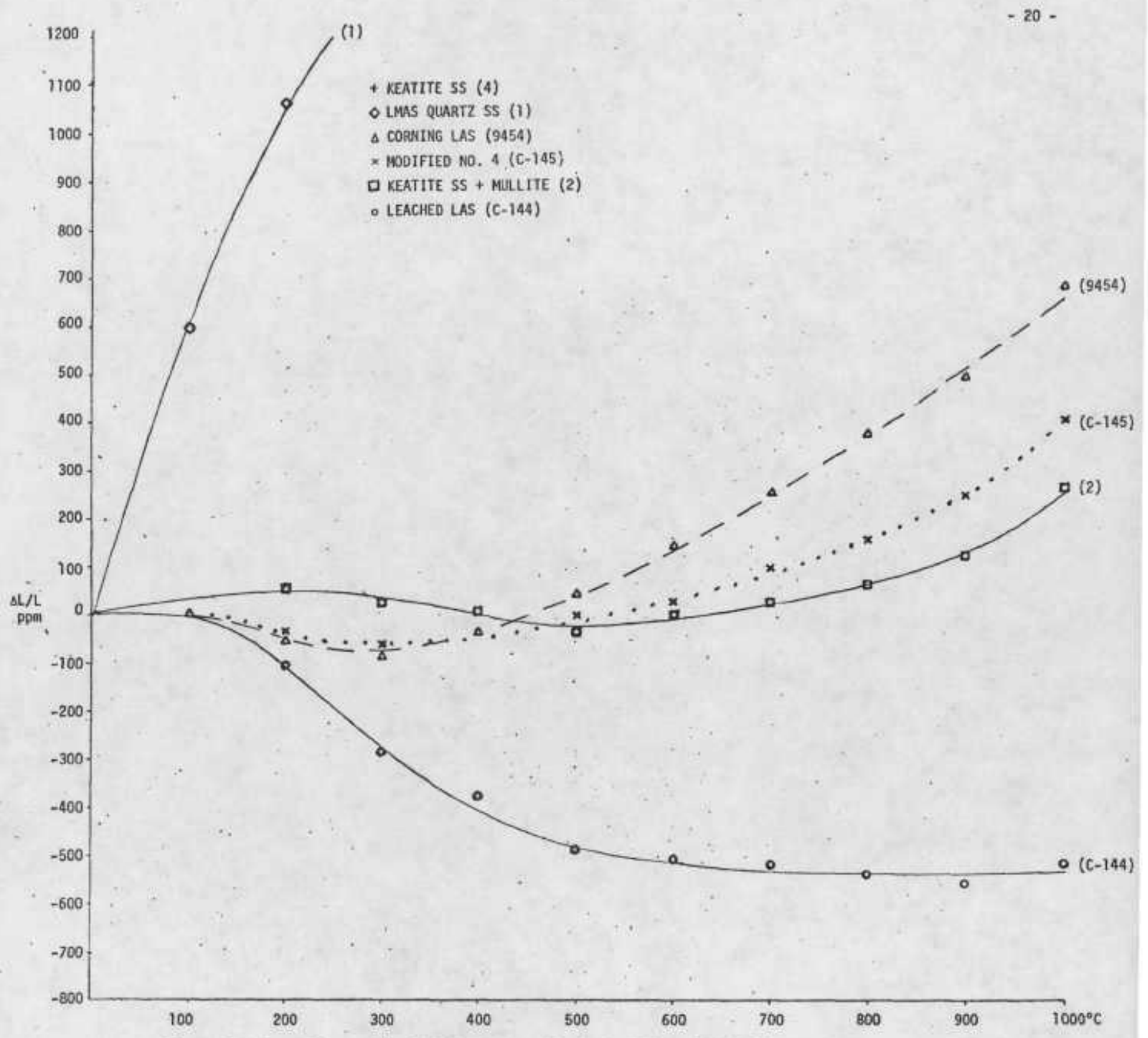

Figure 8 - Thermal Expansion of 9454 and Materlals 1, 2, 3 After $1000^{\circ} \mathrm{C}-1000$ hrs 


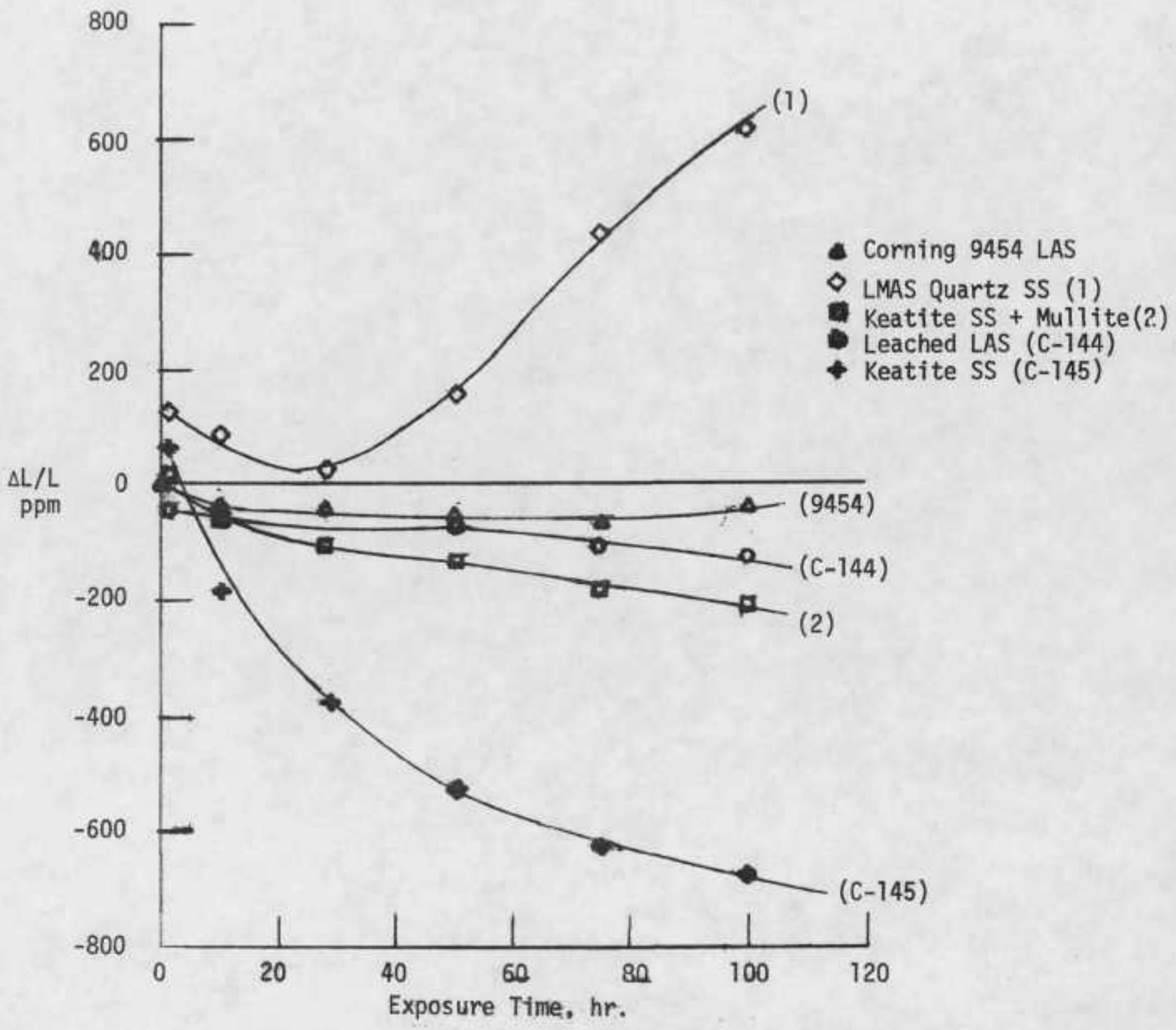

Figure 9 Dimensional Stability at $1000^{\circ} \mathrm{C}$, Length Change after Exposure 


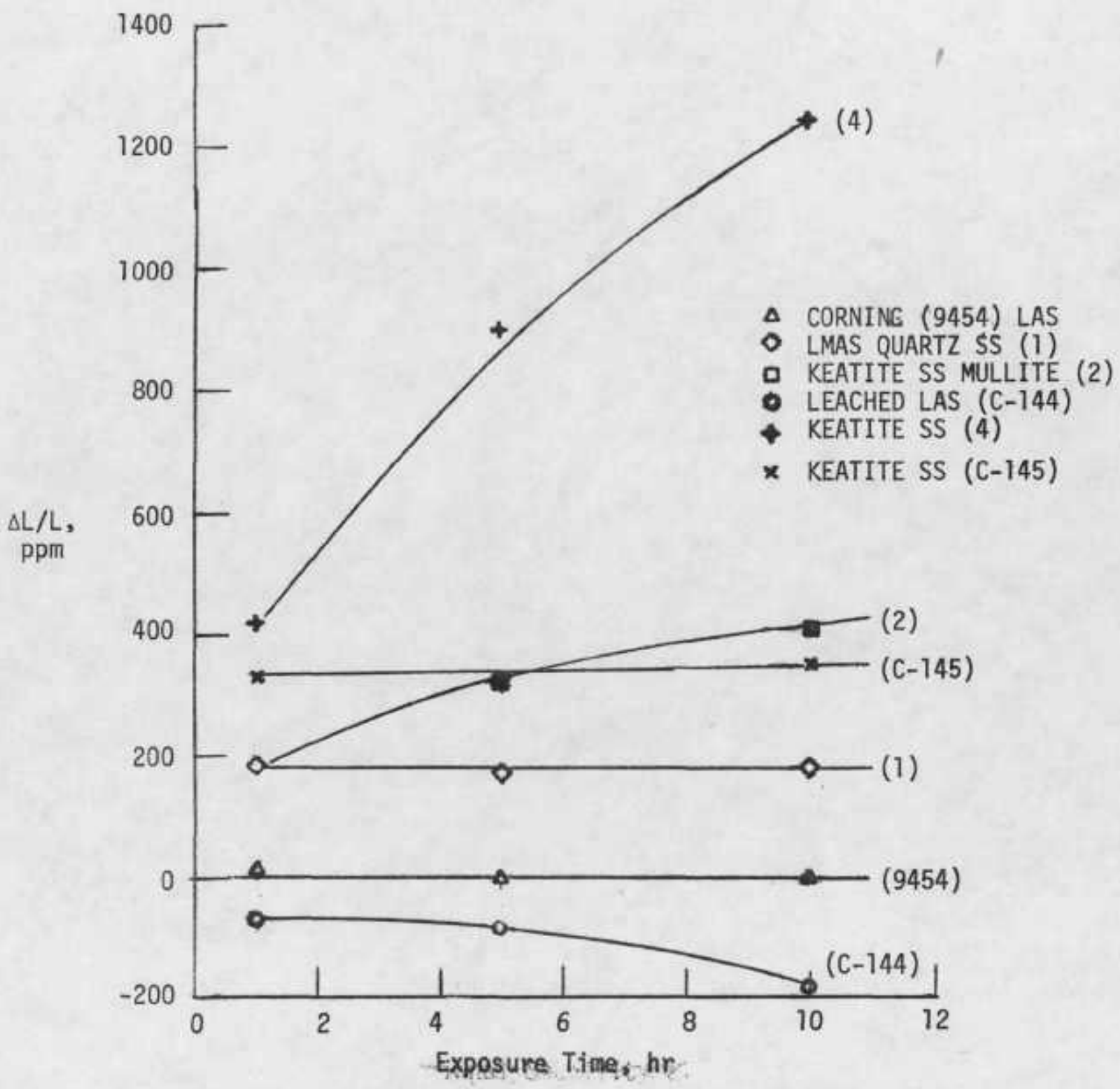

Figure 10 - Dimensional Stability at $1100^{\circ} \mathrm{C}$, Length Change After Exposure 


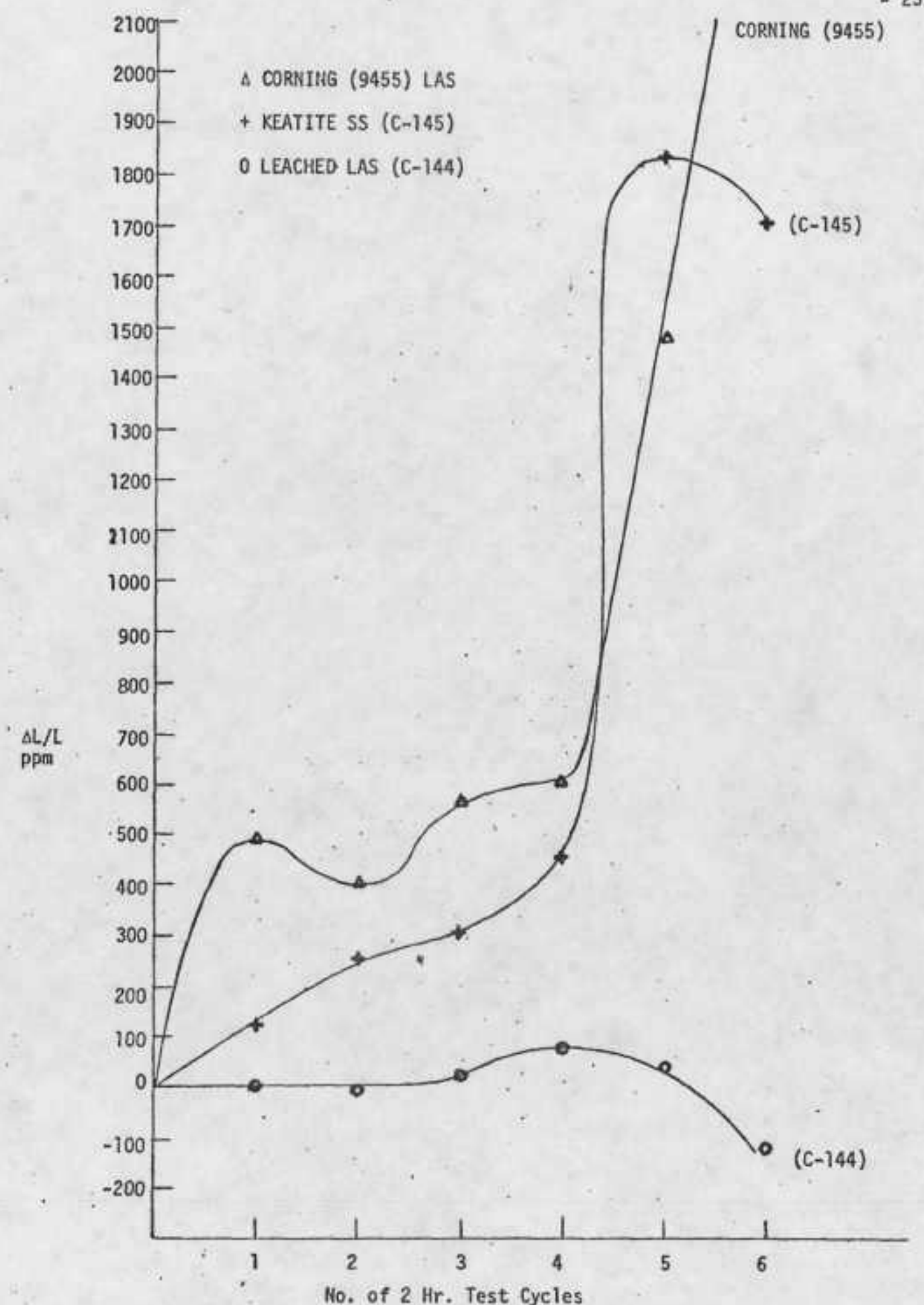

Figure 11 - Matrix Dimension Stability to $300^{\circ} \mathrm{C}$ Sulfuric Acid. Method 1 - Acid Drained by Gravity with no Shaking. 


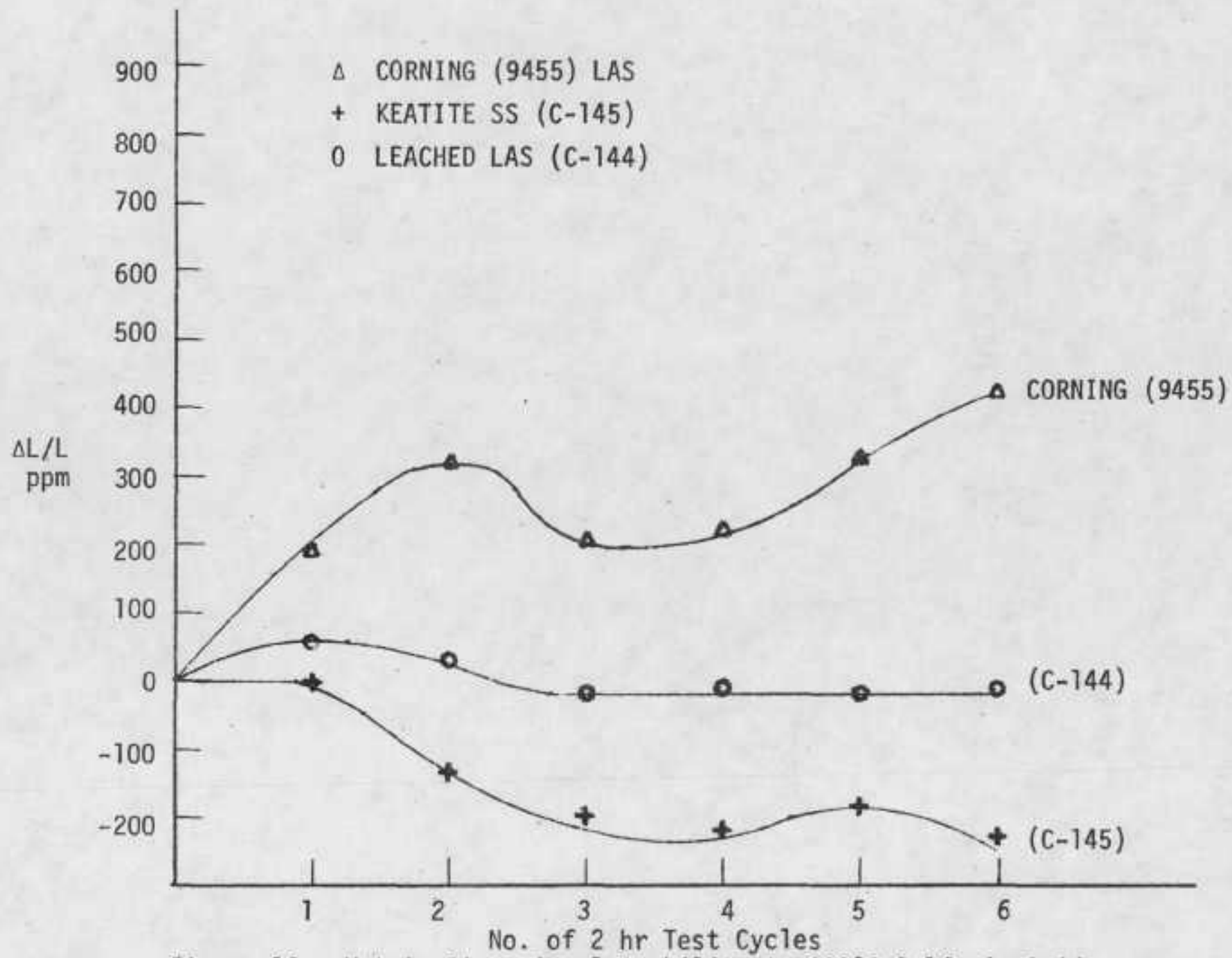

Figure 12 - Matrix Dimensional Stability to $300^{\circ} \mathrm{C}$ Sulfuric Acid. Method II - Acid Drained by Gravity and Shook Twice to Drain More Acid 


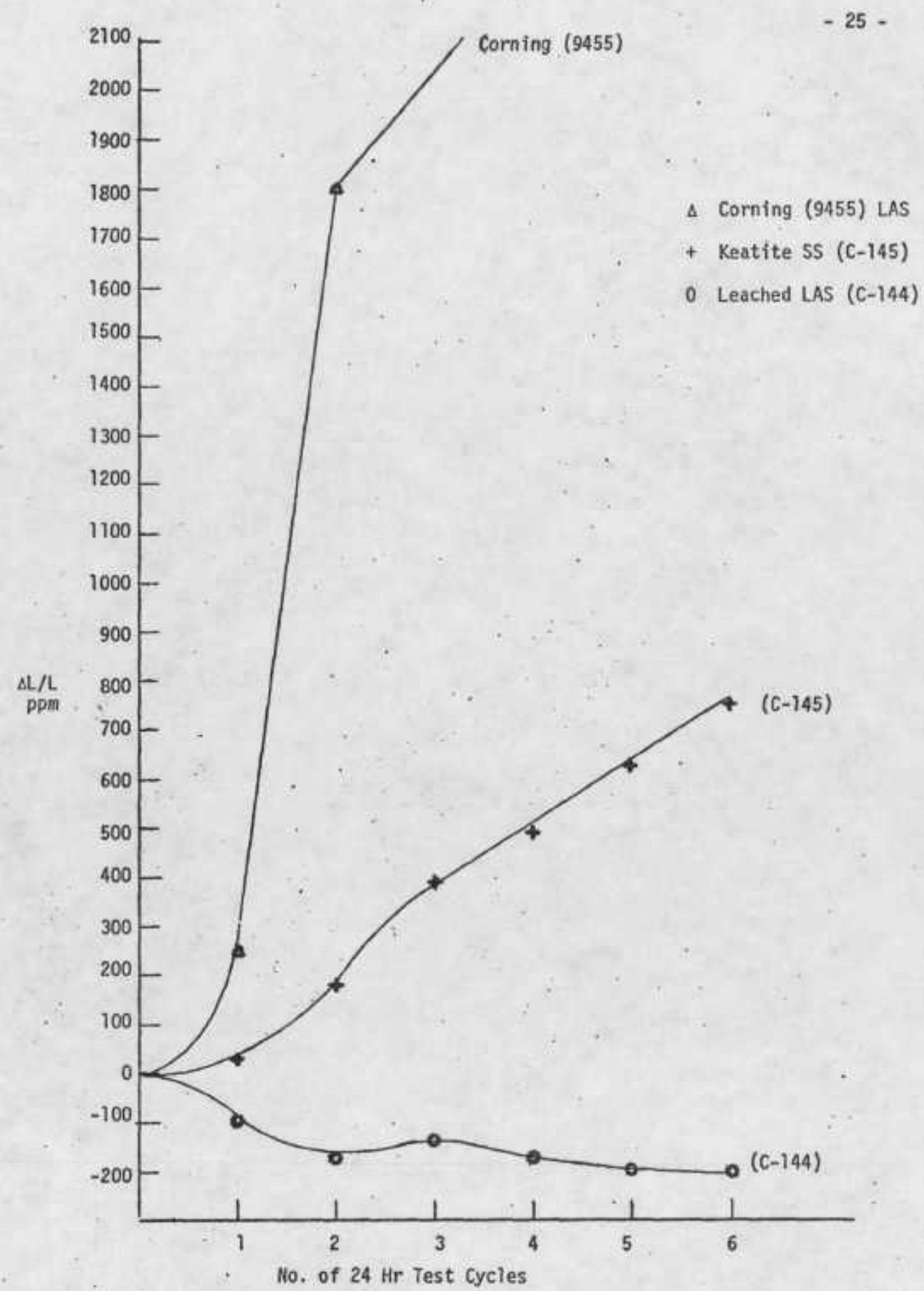

,Figure 13 - Matrix Dimensional Stability to $1000^{\circ} \mathrm{C}$ Sodium Sulfate 


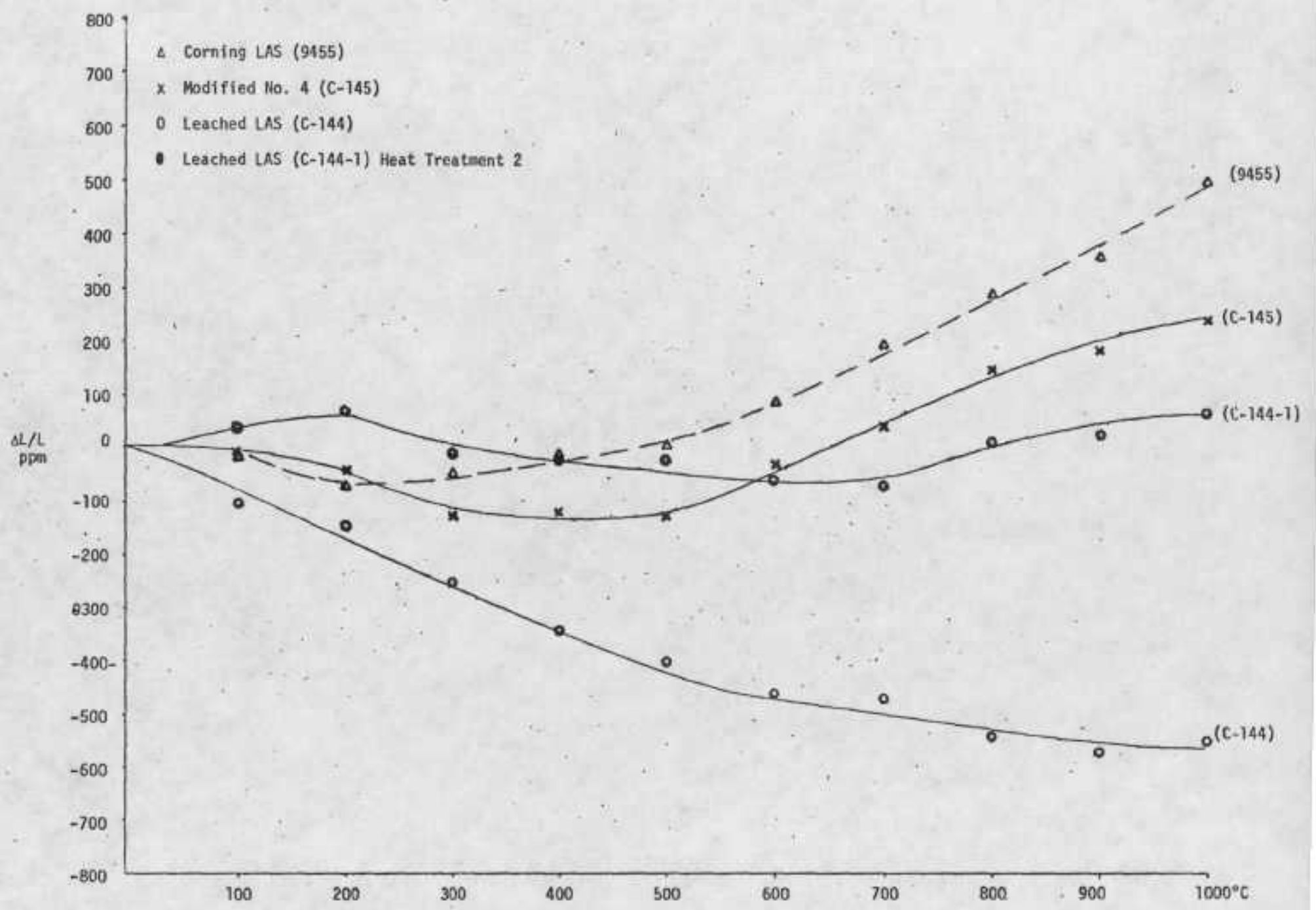

Figure 14 - Matrix Thermal Expansion of 9455 and $\mathrm{C}-144, \mathrm{C}-144-1, \mathrm{C}-145$ after $1000^{\circ} \mathrm{C}-1 \mathrm{Mr}$ 


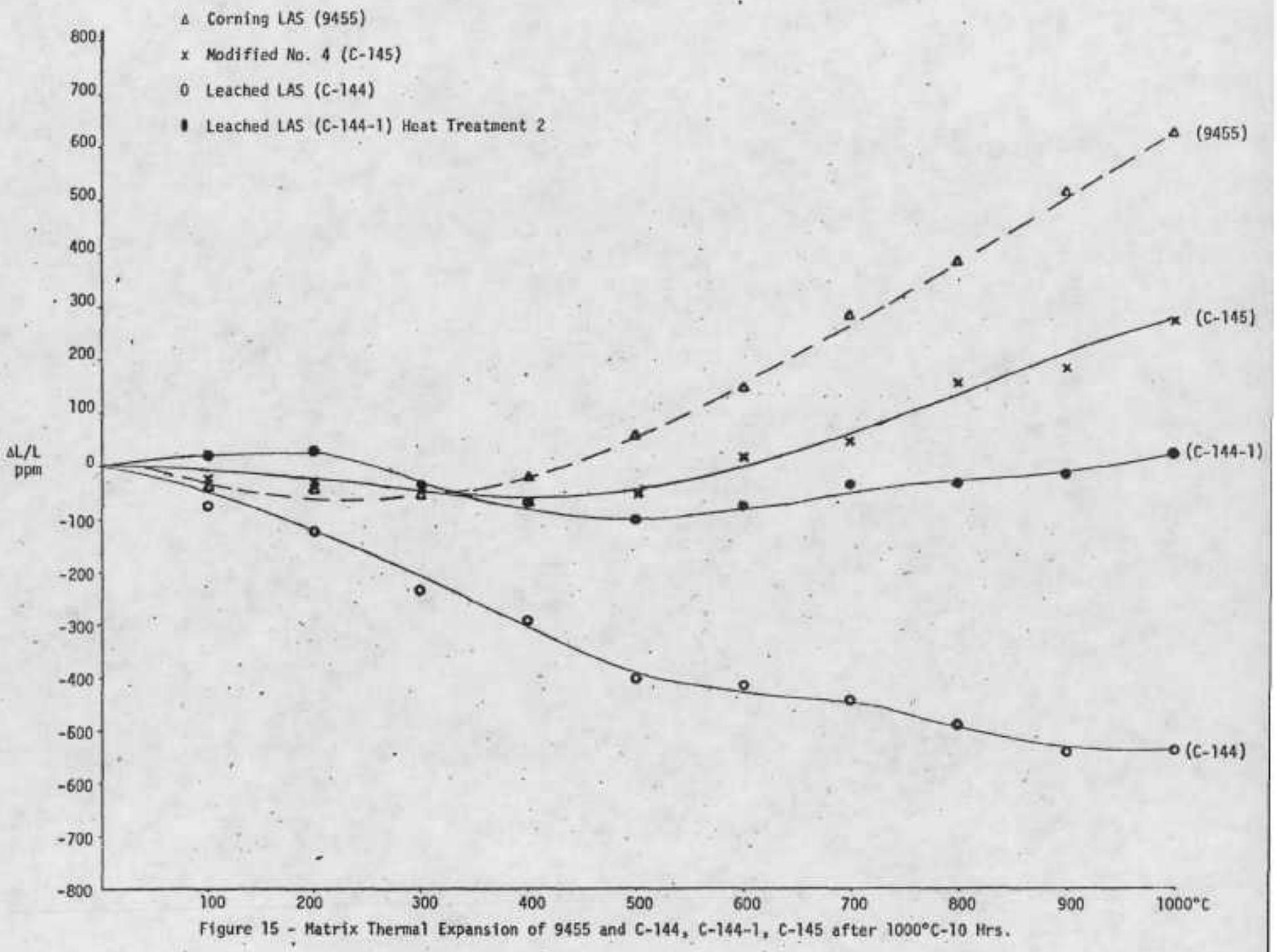




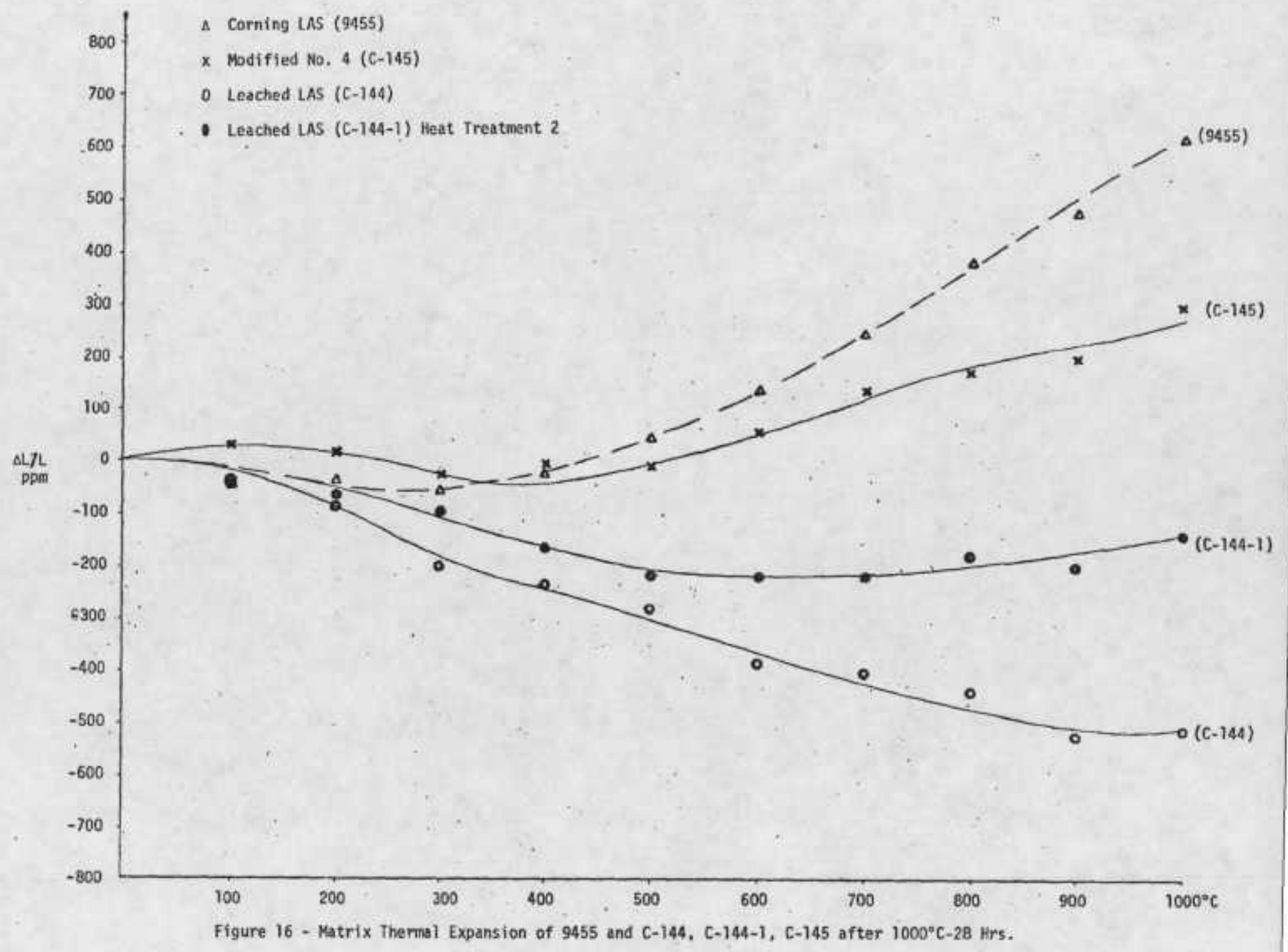




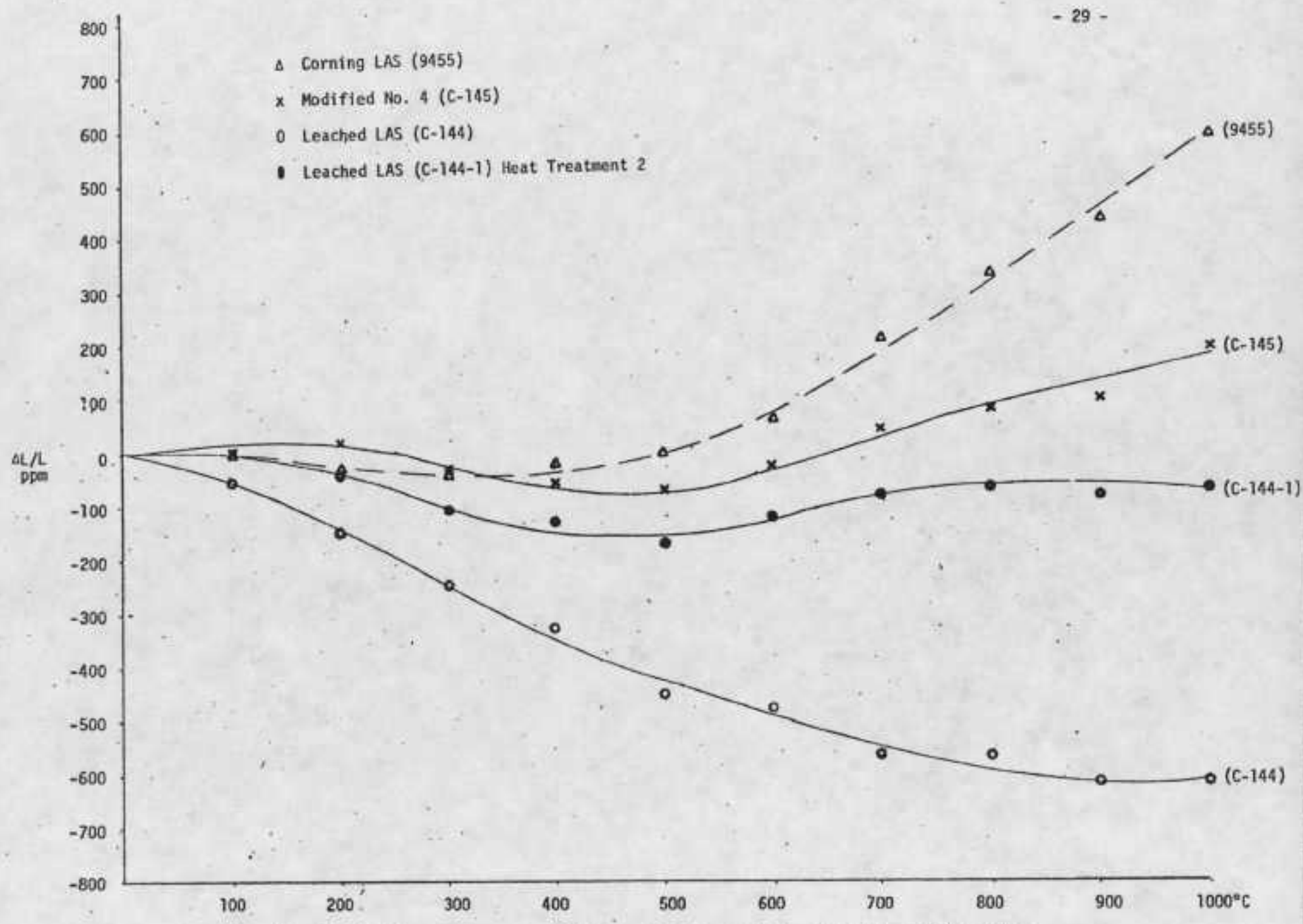

Figure 17 - Matrix Thermal Expansion of 9455 and C-144, C-144-1, C-145 after $1000^{\circ} \mathrm{C}-50 \mathrm{Hrs}$. 


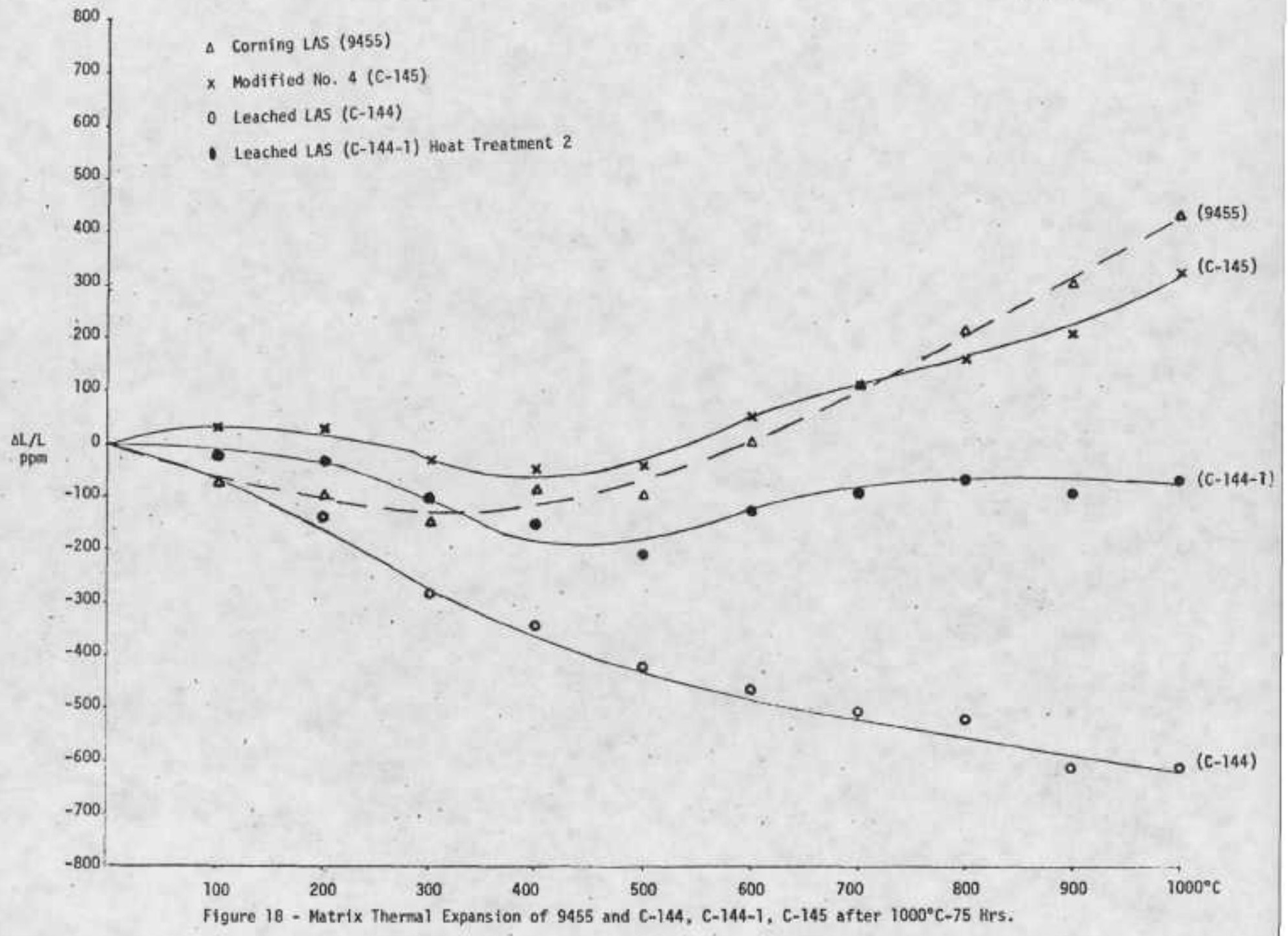




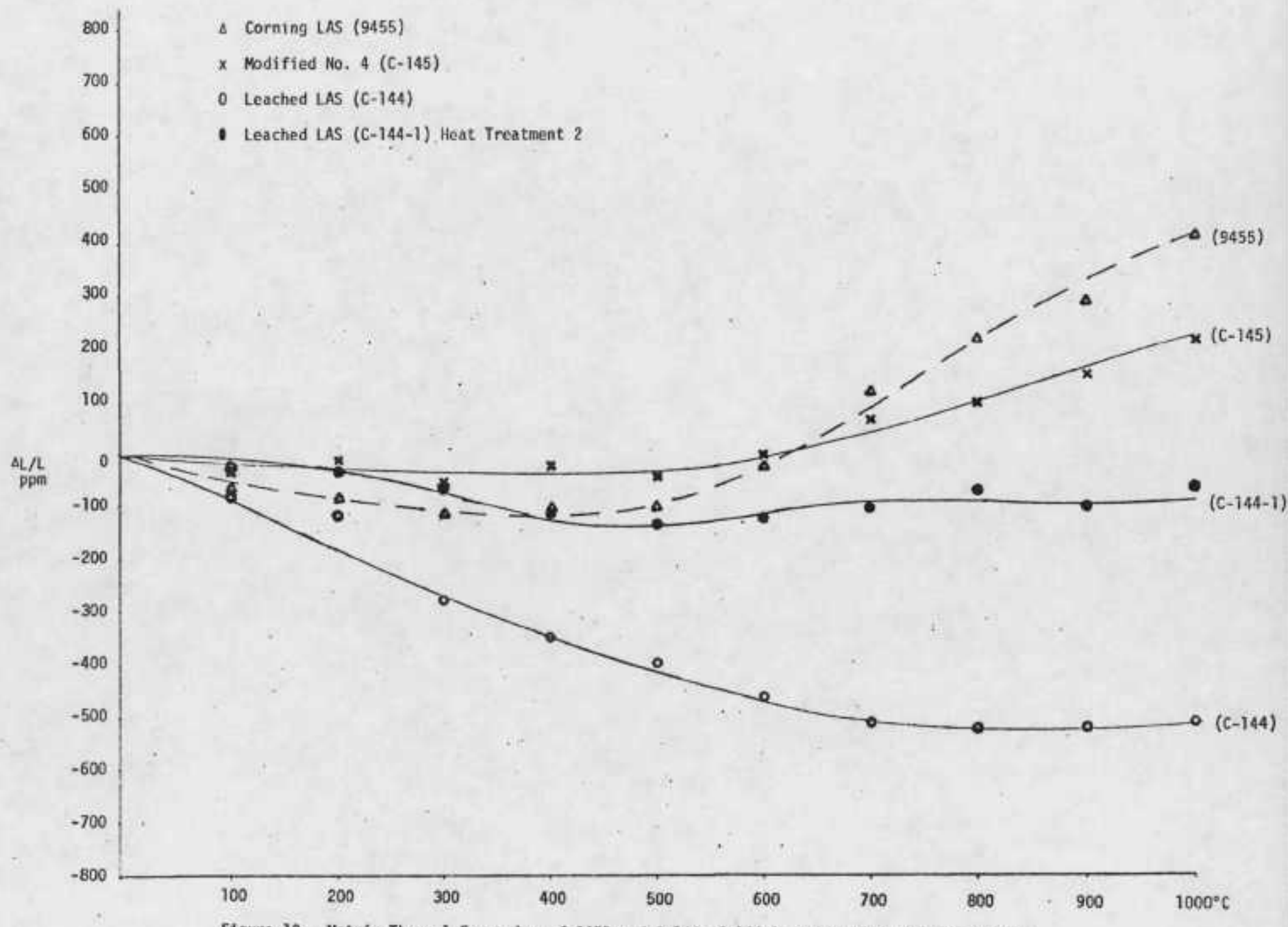

Figure 19 - Matrix Thernal Expansion of 9455 and C-144, C-144-1, C-145 after $1000^{\circ} \mathrm{C}-100 \mathrm{Hrs}$. 


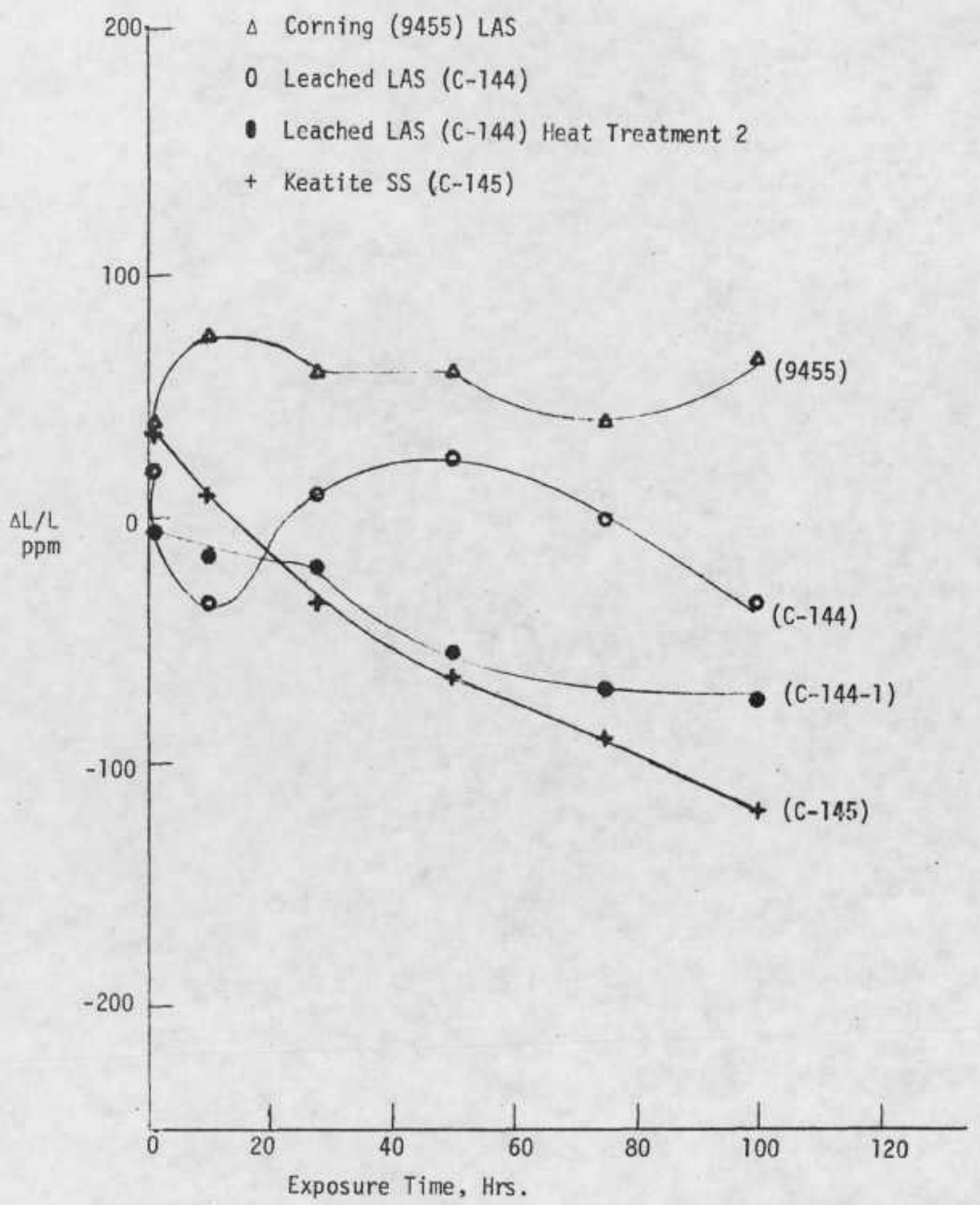

Figure 20 - Matrix Dimensional Stability at $1000^{\circ} \mathrm{C}$, Length Change after Exposure. 


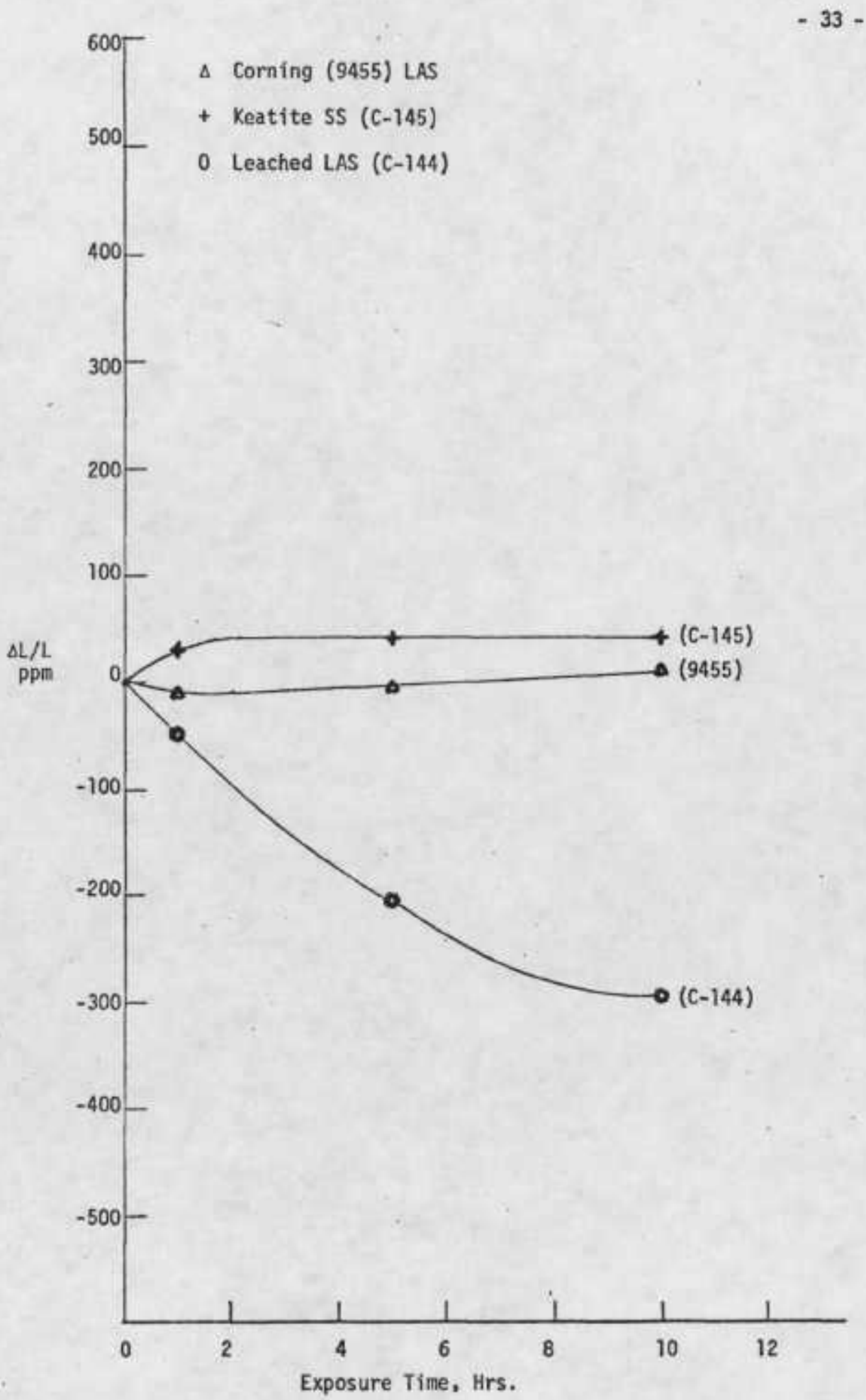

Figure 21 - Matrix Dimensional Stabi1ity at $1100^{\circ} \mathrm{C}$, Length Change af ter Exposure. 
FIGURE 13. GLASS-CERAMIC MATERIALS

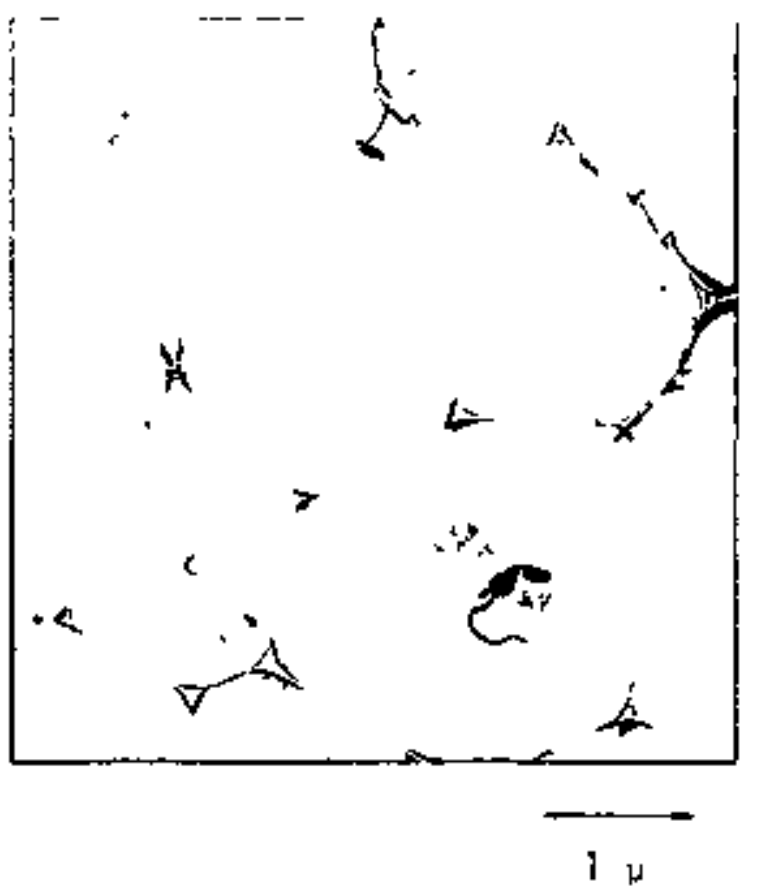

MATERIAL 1

LMAS Quartz SS

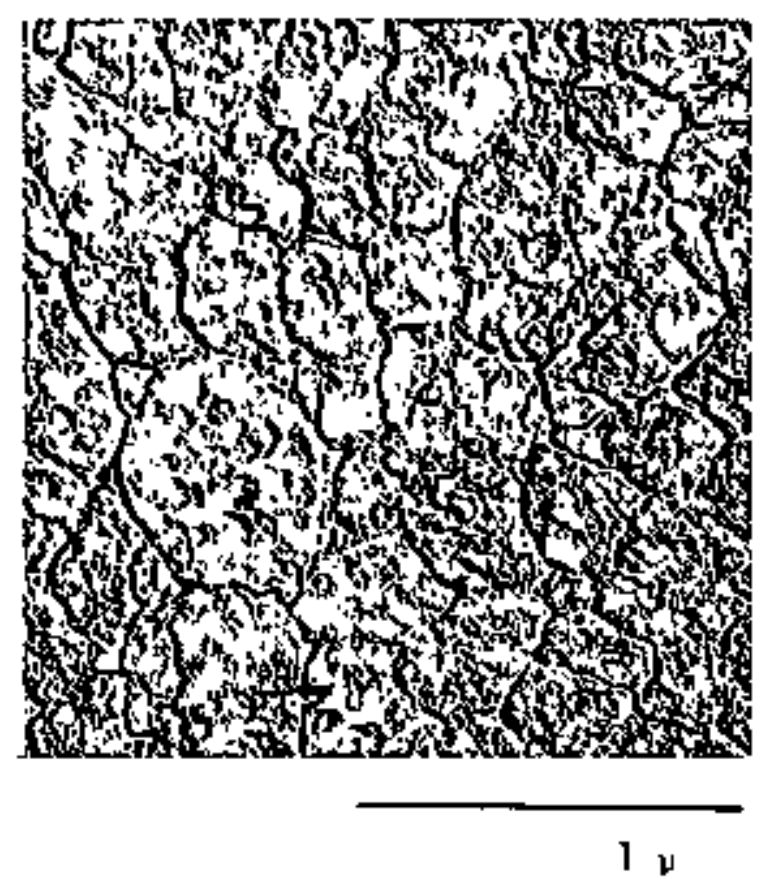

C-144

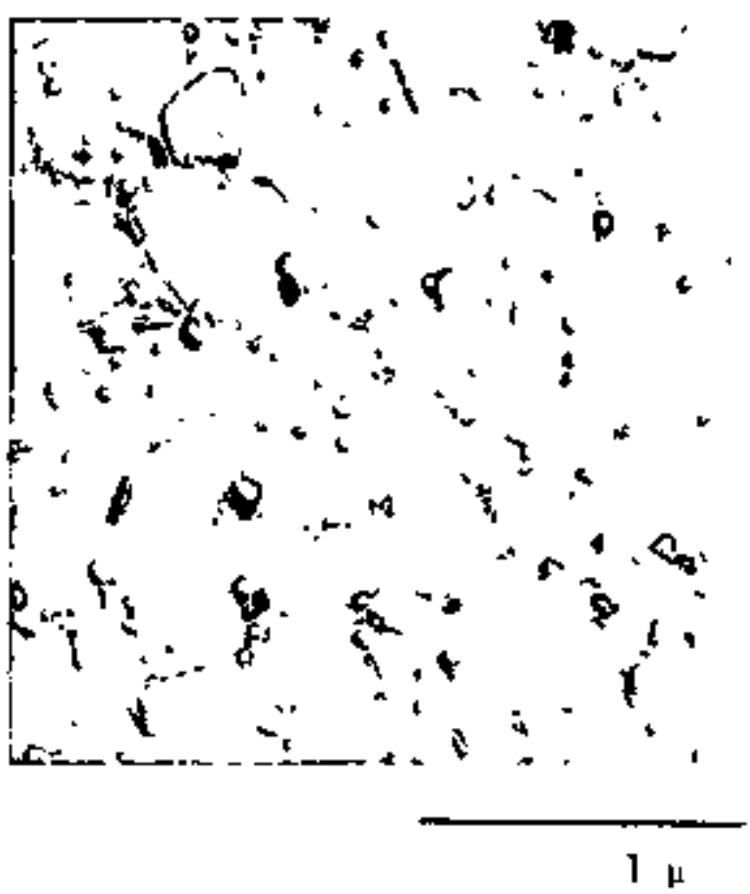

MATERIAL 2

Keatite SS + Mullite

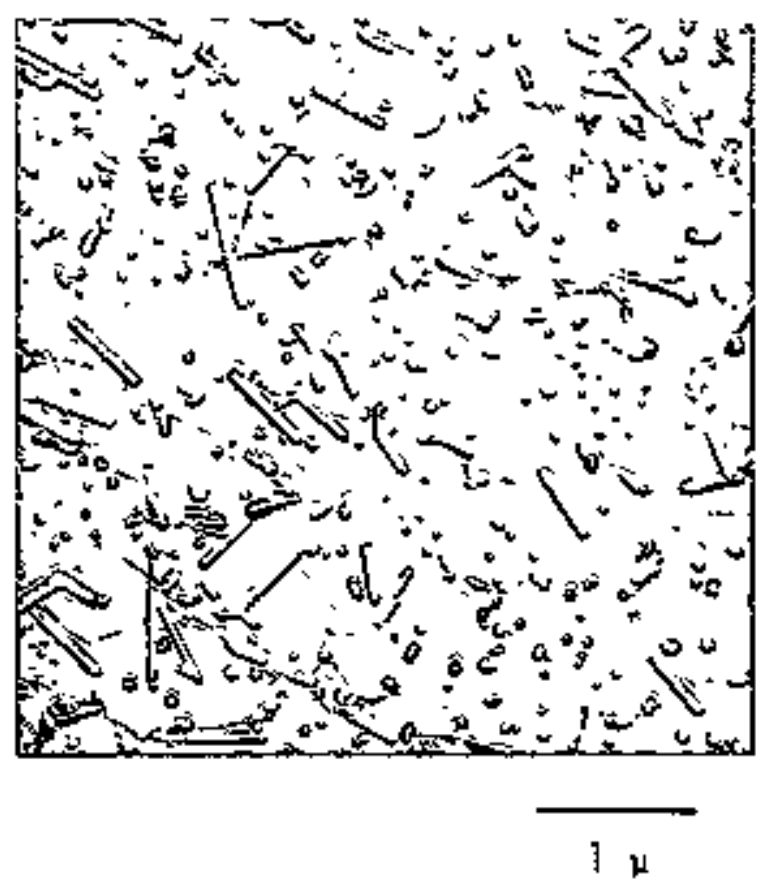

C- 145 
CONS/733-1

NASA CR-135262

\section{IMPROVED CERAMIC HEAT EXCHANGE MATERIAL}

H. L. McCollister

OWENS-ILLINOIS, INC.

Toledo, Ohio

September 1977

Prepared for the

NATIONAL AERONAUTICS AND SPACE ADMINISTRATION Lewis Research Center

Cleveland, Ohio 44135

Contract NAS 3-19733

As a part of the

ENERGY RESEARCH AND

DEVELOPMENT ADMINISTRATION

Division of Transportation Energy Conservation

Heat Engine Highway Vehicle Systems Program 
Summary

The objective of this progran is to develop improved corrosion resistant ceramic materials suitable for use as regenerative heat exchangers for vehicular gas turbines. The major material requi rements are low therma 1 expansion up to $1000^{\circ} \mathrm{C}$, lang time dimensional stability up to $1000^{\circ} \mathrm{C}$, the ability to operate at least for short times up to $1100^{\circ} \mathrm{C}$, and corrosion resistance.

In Task I, four crystalline glass-ceramic materials were studied in solfd form as $2.5 \mathrm{~cm} \mathrm{0.D.} \times 3.8 \mathrm{~cm}$ rods. All materials $1,2, \mathrm{C}-144$, and $\mathrm{C}-145$ have improved resistance to chemical attack resulting from the presence of sulfuric acid and Sodium salts which lifmits the life of Coming LAS 9455 heat exchange material.

Material $I$ is composed of high quartz SS, material 2 contains keatite SS plus mullite, material [-144 is a leached LAS material wose major crystalline phase is silita keatite plus mullite, and material C-145 is composed of keatite SS.

Three of the candidate materials $2, C-144$, and $C-145$, have strength, thermal expansfon, thermal dimensional stability, and phase stability either better than or comparable to material 9455.

The most severe sulfuric acid attack on the candidate materials was more than an order of magnitude less than solid material 9454. Solid materfals C-144 and C-145 showed no attack from sodium while materiais 1 and 2 were marginally better than material 9454 .

Materials C-144 and C-145 were chosen, based on their excellent resistance to sulfuric acid and sodium sulfate, to be fabricated into honeycomb matrix for property testing in Task II.

Results indicate that material C-144 is two orders of magnitude better than Corning LAS matrix 9455 in dimensional stability to 541 furic acid at $300^{\circ} \mathrm{C}$. Material C-145 is twice as good as 9455 in dimensional stability to sulfuric acid after three exposure cycles and is about equal to 9455 after six cycles.

Sodium sulfate corrosion tests indicate that material $5-144$ is one order of magnitude better than material 9455 in stability to sodium sulfate at $1000^{\circ} \mathrm{C}$ after six exposure cycles. Material C-145 is one order of magnitude better than 9455 after three cycles and about four times better after six exposure cycles.

Both $\mathrm{C}-144$ and $\mathrm{C}-145$ have less than $300 \mathrm{ppm} \Delta \mathrm{L} / \mathrm{L}$ therma $]$ expansion from ambient to $7000^{\circ} \mathrm{C}$, and good dimensional stabllity of less than $\approx 100 \mathrm{ppm} \Delta \mathrm{L} / \mathrm{L}$ change in Tength after exposure to $1000^{\circ} \mathrm{C}$ for 100 hours. Materials 9455 and $\mathrm{C}-145$ have better dimensional stability at $1100^{\circ} \mathrm{C}$ than materjal $\mathrm{C}-144$ which contracts about $300 \mathrm{ppra} \Delta \mathrm{L} / \mathrm{L}$ after 10 hours while materials 9455 and $\mathrm{C}-145$ expand less than $40 \mathrm{ppm} \Delta L / L$.

The glass-ceramtc fabrication process of $\mathrm{C}-144$ and $\mathrm{C}-145$ produced a hexagonal isotropic honeycomb matrix having a passage diameter of $700 \mathrm{um}(0.028 \mathrm{in}),. 50 \mathrm{um}(0.002$ in.) wall thickness, 170 passages $/ \mathrm{cm}^{2}\left(1100 /\right.$ in. $\left.^{2}\right)$, 85\% open frontal ared, and less than $5 \%$ porosity. Because of the much thinner 50 m wall, $450 \mathrm{KPa}$ (65 psi) tensile strengths measured perpendicular to the open passages of C-144 and C-145 are $10 \mathrm{w}$ compared to the thicker walled (130-305 $\mu \mathrm{m}) 9455$ anisotropic matrix which has a tensile strength of $1800 \mathrm{kPa}(260 \mathrm{ps} i)$ in the radial direction and $4800 \mathrm{KPa}$ (700 psi) in the tangential direction. 


\section{Table of Contents}

\section{Sumary}

Page

Table of Contents ii

List of Tables $\quad$. 111

List of Figures

1. Introduction 1

2. Results and Discussion of Task I - Bulk Properties

2.1 Sulfuric Acíd

2.2 Sodium Sulfate

2.3 Thermal Expansion

2.4 Thermal Phase Stability

2.5 Elastic Moduius and Modulus of Rupture

3. Results and Discussion of Task II - Matrix Properties

3.1 Sulfuric Acid

3.2 Sodium Sulfate

3.3 Thermal Expansion

3.4 Thermal Phase Stability

3.5 Elastic Modulus and Modulus of Rupture

3.6 Microstructure and Porosity

4. Conclustions 


\section{List of Tables}

Table

1 Depth of Sulfuric Acid Reaction 9

2 Depth of Sodium Sulfate Reaction. , 9

3 Young's Hodulus 10

4 Modulus of Rupture 10

5 Dimensional Stability $\Delta \mathrm{L} / \mathrm{L}$ Ppm to Sodium Sulfate at $1000^{\circ} \mathrm{C}$ for $24 \mathrm{Hr}$. Cycles Ys. Specimen Cross Sectional Area 11

6 Modulus of Rupture and Elastic Modulus 11

7 Matrix Porosity $\quad$ I2

\section{List of Fjqures}

\section{Flgure}

1 Reaction Depth after 80 Hrs of $300^{\circ} \mathrm{C}$ Sulfuric Acid

2 Reaction Depth after Six $24 \mathrm{Hr}$ Cycles of Sodium Sulfate at $1000^{\circ} \mathrm{C}$

3 Thermal Expansion of 9454 and Materials $1,2,3,4$ after $1000^{\circ} \mathrm{C}-1-\mathrm{Hr}$

4 Thermal Expansion of 9454 and Materials 1,2,3,4 after 1000C-10 Hrs

5 Thermal Expansion of 9454 and Materials 1,2,3,4 after $1000^{\circ} \mathrm{C}-28$ Hrs

6 Thermal Expansion of 9454 and Materials $\mathrm{I}, 2,3,4$ after $1000^{\circ} \mathrm{C}-50 \mathrm{Hrs}$

7 Thewal Expansion of 9454 and Materials $\mathrm{I}, 2,3,4$ after $1000^{\circ} \mathrm{C}-75$ Hrs

8 Themal Expansion of 9454 and Materials $1,2,3,4$ after $1000^{\circ} \mathrm{C}-100 \mathrm{Hrs}$

9 Dimensional stability at $1000^{\circ} \mathrm{C}$, Length Change after Exposure

12 Matrix Dimensional Stability to $300^{\circ} \mathrm{C}$ Sulfuric Acid - Method 2

13 Matrix Dimensional Stability to $1000^{\circ} \mathrm{C}$ Sodicm Sulfate

14 Matrix Thermal Expansion of 9455 and $C-144, C-144-1, C-145$ after $1000^{\circ} \mathrm{C}-1 \mathrm{Hr}$

15 Matrix Thenmal Expansion of 9455 and $\mathrm{C}-144, \mathrm{C}-144-1, \mathrm{C}-145$ after $1000^{\circ} \mathrm{C}-10$ Hrs

16 Matrix Therma 1 Expansion of 9455 and C-144, C-l44-1, C-145 after $1006^{\circ} \mathrm{C}-28$ His

17 Matrix Thermal Expanston of 9455 and $C-144, C-144-I, C-145$ after $1000^{\circ} \mathrm{C}-50$ Hrs

18 Matrix Thermal Expansion of 9455 and $C-144, C-144-1, C-145$ after $1000^{\circ} \mathrm{C}-75 \mathrm{Hrs}$

19 Matrix Thermal Expansion of 9455 and $C-144, C-144-1, C-145$ after $1000^{\circ} \mathrm{C}$ - 100 Hrs

20 Matrix Dimensional Stabllity at $1000^{\circ} \mathrm{C}$, Length Change after Exposure 
Figure

21 Matrix Dtmensional Stability at $1100^{\circ} \mathrm{C}$, Length Change after Exposure

22 Glass-Ceramic Materials 1, 2, C-144, and C-145

33

34

1

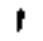




\section{Introduction}

The objective of this prograr is to develop ceramic materials suitable for use as regenerative heat exchangers for vehicular gas turbines. In Task I of contract NAS3-19733, four materiais were investigated to overcone the chemical attack resulting from the presence of sulfuric acid and sodium which $1 j$ it the life of lithium aluminosilicate (LAS) heat exchange materials. The four glass-ceramic candidate materials are:

1. A (LKAS) material whose major crystalline phase is high quartz solid solution (\$S).

2. A (LAS) material whose major crystalline phase is keatite SS plus mullfte.

3. CER-YIT ${ }^{(R)}$ material C-144, leached (LAS) material whose major crystalline phase is silica keatite plus mulite.

4. A (LAS) material whose major crystalline phase is keatite SS.

4-1 CER-VIT ${ }^{(R)}$ material C-145, a siljca compositional iteration to material 4 which produced an acceptable lower thermal expansion material.

The major material requirements are Jow thermal expansion up to $1000^{\circ} \mathrm{C}$, long time dimensional stability up to $1000^{\circ} \mathrm{C}$, and the abflity to operate at least for short times up to $1100^{\circ} \mathrm{C}$. The four candidate materials are designed to have strength, thermal expansion, thermal dimensional stability and phase stabilfty, and thermal shock resistance comparable to the Corning 9454 solid material, but have improved corrosion resistance with respect to sulfuric acid and sodium salts. As a result of the materials testing program on bulk specimens carried out during Task $I_{2}$ al] four cancidate materials show superior corrosion resistance to both sulfuric acid at $300^{\circ} \mathrm{C}$ and $50 d i$ tim sulfate at $1000^{\circ} \mathrm{C}$ compared to material 9454 . A summary of Jask $I$ test results is presented in Section 2.

Two of the candidate materials (3 and 4-1) were chosen, based on their excellent resistance to sulfuric acid and sodium sulfate, to be fabricated into honeycomb matrix for property testing under Task II. Material 3 has been designated OwensIllinois CER-VIT(R) material $C-144$ and material 4-] as CER-VIT(R) waterial C-145. As a result of the materials testing program on honeycomb specimens carried out in Task II, CER-VIT $(R)$ materials C-144 and C-145 show superior corrosion resistance to both sulfuric acid and sodium sulfate compared to Corning matrix LAS 9455 heat exchange material. A summary of Task II test results is presented in Section 3.

\section{Results and Discussion \\ Task I - Bulk Properties}

As a result of the materials testing program on bulk specimens carried out during Task I of the contract, all four candidate materials show superior corrosion resistance to sulfuric acid at $300^{\circ} \mathrm{C}$ compared to Corning material 9454 . Figure 1

${ }^{(R)}$ CER-VIT is a registered trademark of awens-IIlnois. Inc. 
shows that the most severe attack on the candidate materiais is more than an order of magnitude Tess than material 9454 . Ho reaction was observed for material C-144 after six exposure cycles as show in Table $l$.

Results of sodium sulfate corrosion tests as shown in Figure 2 indicate that no reaction was observed for material $\mathrm{C}-145$ after $\mathrm{s} 1 \mathrm{x}$ exposure cycles. The resistance of material $\mathrm{C}-144$ to sodium sulfate is dependent on final thenal treatment as shown in Table 2. After three cycles, no reaction was observed for the $\mathrm{C}-144$ material thermally treated at $1150^{\circ} \mathrm{C}$.

Figures 3 through 8 show the expansion of material 9454 and candidate materials $I$, $2, \mathrm{C}-144$ and $\mathrm{C}-145$ after exposure to $1000^{\circ} \mathrm{C}$ for $1,10,28,50,75$ and 100 hours, respectively. Three of the candidate materials $(2, \mathrm{C}-144$ and $\mathrm{C}-145)$ have the desired thermal expansion from ambient to $1000^{\circ} \mathrm{C}$ of less than $800 \mathrm{ppm} \Delta \mathrm{L} / \mathrm{L}$ as shown in Figure 8 after thentai treatment at $1000^{\circ} \mathrm{C}$ for 100 hours.

Dimensional stability to $1000^{\circ} \mathrm{C}$ and $1100^{\circ} \mathrm{C}$ exposures has been deternitined as showm 1n Figures $g$ and 10 , respectively, None of the materials is as stable as material 9454; however, materials 2 and $C=144$ have acceptable dimensional stabitity. Material $\mathrm{C}-145$ (Figure 9) contracts at $1000^{\circ} \mathrm{C}$ and starts to reach equilibrion after $1000^{\circ} \mathrm{C}$ for 75 hours, while therma) treatment at $1100^{\circ} \mathrm{C}$ (Figure jo) causes the material to expand. The effect of heat treatment teriperature and resulting dimensional stability at $1000^{\circ} \mathrm{C}$ was investigated in Task II matrix testing and a C-145 material was produced which has good dimensional stability of less than * $100 \mathrm{ppm} \mathrm{AL} / \mathrm{L}$ change at $1000^{\circ} \mathrm{C}$. Data of Young's modulus, Poisson's ratio and modulus of rupture are show in Tables 3 and 4 , respectively. Candidate materials 1,2 and $C-145$ have higher Young's moduli and moduli of ruptures than materiai 9454. Data for material C-144 were not obtained because of the presence of microcracks in bulk specimens $1 / 2 \mathrm{~cm}$ thick which interfere with the sonic resonance test for determining Young's modulus. These microcracks are not present in thin-wal led honeycomb matrix of material $\mathrm{C}-144$.

Mercury porosimetry results indicate that materials 1,2 and $\mathrm{C}-145$ have a net pore volume of $0.002 \mathrm{cc} / \mathrm{gram}$, while the chenically leached and thermally treated material $\mathrm{C}-144$ has a net pore volume of $0.0098 \mathrm{cc} / \mathrm{gram}$. The average pore diameter is 0.005 and $2.10 \mathrm{\mu m}$, respectively.

\subsection{Sulfuric Acid}

Specimens 2.5 cm diameter and $3.8 \mathrm{~cm}$ long were $\$$ ubjected to 900 milliliters of $96 \%$ sulfuric acid at $300^{\circ} \mathrm{C}$ for $\$ 1 x$ exposure times. The specimens were contained in $K I M A X(R)$ glass reaction vessels heated by Gas-col heating mantles. The acid is preheated in a separatory funnel and delivered hot to the reaction vessel which contained one specimen of each material. The acid temperature is controlled to $\pm l^{\circ} \mathrm{F}$ by a thermocouple suspended into the acid.

Sulfuric acid reacts with LAS materials by exchanging hydrogen ions for 1 thitum. This ion exchange reaction produces cracking in the microstructure if large specimen cross sections are involved. The depth of ion exchange is measured by optical microscopy. Figure 1 shows the reaction depth into the materials after 80 hours of $300^{\circ} \mathrm{C}$ sulfuric acid exposure. 
Table 1 gives the reaction depth in millimeters vs, exposure time in sulfuric acid. The average reaction depth for three specimens is reported.

Further characterization of material C-144 indicates that the material has no weight loss after acid exposure. A change in specimen length of $13 \mathrm{ppja} \Delta \mathrm{L} / \mathrm{L}$ was measured after 80 hours of acid exposure at $300^{\circ} \mathrm{C}$.

\subsection{Sodtum Sulfate}

In situ $X$-ray diffraction of sodjum sulfate reacted specimen surfaces have been evaluated to determine the depth of ion exchange of Ha for Li. Sodium expands the crystal lattice of LAS keatite and a marked change in crystal " 0 " spacing occurs in the jon exchanged surface layer. The depth of ion exchange on bulk specimens is obtained by mechanically grinding off the sodiun sulfate exposed surface until no change in crystal " 0 " spacings is observed as coapared to the original unreacted specimen surface.

The test consists of covering a specimen surface area of $3.4 \mathrm{~cm}$ with 0.0170 grams of anhydrous sodium sulfate and heating the coated specisen at $1000^{\circ} \mathrm{C}$ for 24 hours. Six exposure cycles are measured to determine the reaction depth. Materiat is ground off in 10 to um intervals depending on the raterial and the extent of the surface reaction.

Figure 2 shows the reaction depth into the materials after six exposure cycles of sodium sulfate.

Table 2 shows the reaction depth for the materials after each 24 bour cycle. Corning material 9454 and material 2 (both LAS keatite materials) undergo an ion exchange of $\mathrm{Na}$ for $\mathrm{Li}$ when exposed to sodium sulfate as a marked change in crystal " 0 " spacing is observed by X-ray diffraction. Materlal 1, with a "stuffed" high quartz solid solution crystalline phase, does not show any change in crystal " 0 "spacings but the surface ts altered by secondary crystallization forming (LAS) keatite S.S. and amorphous aterfal with less intense high quartz 5.5 . crystajline peaks.

The resistance of material C-144 to sodium sulfate is dependent on final thermal treatment after acid leaching the 1 ithia from the keatite structure as shown in Table 2. The reacted surface contains $\mathrm{SiO}_{2}$ cristobalite; also, amorphous material is sometimes found.

Materia] C-145 looks very promising with respect to sodium sulfate resistance in that no reaction has been detected for the six exposures to sodium sulfate. Further testing of this material in sheets 0.7 to $1 \mathrm{~mm}$ in thickness with sodium sulfate applied to one surface Indicates no warpage after $1000^{\circ} \mathrm{C}$ for 64 hours. Exposure cycles at 24 hour intervals indicate that warpage does occur after the third exposure. This is belfeved due to a build-up of fused salt on the materials surface which is measured after each application of sodiua sulfate.

\subsection{Thermal Expansion}

The thermal expansion $A L / L$ in $\mathrm{ppm}$ over the temperature range of aubient to $1000^{\circ} \mathrm{C}$ for the candidate materials and 9454 is shown in Figures 3 through 8 . The standard; deviation is $30 \mathrm{ppm} \Delta \mathrm{L} / \mathrm{L}$ for the three specimens measured. The thermalf expansion specimens are cycled between ambient and $1000^{\circ} \mathrm{C}$ according to the following schedule: 
1. ten cycles with a 1 hour hold at $1000^{\circ} \mathrm{C}$

2. three cycles with a 6 hour hold at $1000^{\circ} \mathrm{C}$

3. one cycle with a 22 hour hold at $1000^{\circ} \mathrm{C}$

4. two cycles with a 25 hour hold at $1000^{\circ} \mathrm{C}$

Thermal expansion was measured after exposure times at $1000^{\circ} \mathrm{C}$ for $1,10,28,50$, 75 and 100 hours. The specimen length was measured before and after each thermal exposure and thermal expansion test. Figure 9 shows the specinen length change $(\Delta \mathrm{L} / \mathrm{L} \mathrm{ppm})$ after thermal exposure to $1000^{\circ} \mathrm{C}$.

\subsection{Thermal Phase Stability}

Thernal phase stability at $1100^{\circ} \mathrm{C}$ for all materials has been analyzed by X-ray diffraction. Cornting material 9454 and materials $1,2, \mathrm{C}-144$ and $\mathrm{C}-145$ are stable for the 10 exposure cycles (ambient to $1100^{\circ} \mathrm{C}$ with a 1 hour hold for each cycle) with no change in crystal lattice parameter detected. Material 4 is not $\$$ table at $1100^{\circ} \mathrm{C}$ and contains larger amount of crtstobalite in the range of 5-10 wt. * with increasing thermal exposure.

Dimensional stability at $1100^{\circ} \mathrm{C}$ is shown in Figure 10 for Corning material 9454 and the candidate materials. The average dimensional change $s \mathrm{~L} / \mathrm{L} \mathrm{ppm}$ at $1100^{\circ} \mathrm{C}$ for three specimens is reported. Dimensional instability of material 4 can be attributed to the presence of cristobalite.

\subsection{Elastic Modulus and Modulus of Rupture}

Ho values were obtained for saterial $\mathrm{C}-144$ because of the presence of some microcracks in the bulk specimens which interfere with the sonic resonance test. These microcracks are not present in thin-walled honeyconb matrix.

Values for Young' 5 modulus and Poisson's ratios are shown in Table 3 for the other candidate materials.

Three specimens of each candidate material having dimensions of $11.4 \times 1.9 \times 1.3$ cill were broken in four point flexure with the $11.4 \times 1.9 \mathrm{~cm}$ surface being the tensile surface. The outer $\mathrm{kni}$ fe edge span was $8.9 \mathrm{~cm}$ and the inside span was $1.9 \mathrm{~cm}$. Table 4 shows the modulus of rupture values obtained. All fractures started between the $1.9 \mathrm{~cm}$ span and were initiated in the plane of the specimen surface rather than at the edge.

\section{Results and Discussion}

\section{Task II - Matrix Properties}

Two of the candidate materials ( $C-144$ and $C-145$ ) were chosen, based on their excellent resistance to sulfuric acid and sodium sulfate, to be fabricated into honeycomb matrix for property testing under Task II.

As a result of the materfals testing program on honeycomb specimens carried out. in Task 1I, CER-VIT $(R)$ honeycomb $\mathrm{C}-144$ and $\mathrm{C}-145$ show superior corrosion resistance to sulfuric acid and sodium sulfate compared to Corning honeycomb 9455 . Figure 11 shows that material C-144 is two orders of magnitude better than 9455 in dimensional 
stability to sulfuric acjd at $300^{\circ} \mathrm{C}$. Hatertai $\mathrm{C}=145$ is twice as good as 9455 in dimensional stability to sulfuric acid after three exposure cycles and is about equal to 9455 after six cycles.

Results from sodium sulfate corrosion tests, as shown in figure 13 and tabulated in Table 5, indicate that materiat $\mathrm{C}-144$ is one order of magnitude better in stability to sodium sulfate at $1000^{\circ} \mathrm{C}$ after $51 x$ exposure cycles than material 9455. Haterial C-145 is one order of magnitude better than 9455 after three cycles and about four times better after six exposure cycles.

Figures 14 through 19 show the expansion of materials $9455, \mathrm{C}-144, \mathrm{C}-144-1$ and $\mathrm{C}-145$ after exposure to $1000^{\circ} \mathrm{C}$ for $1,10,28,50,75$ and 1000 hours, respectively. Both materials $C=144$ and $C-145$ have less than $600 \mathrm{ppm} \Delta \mathrm{L} / \mathrm{L}$ themal expansion from ambient to $1000^{\circ} \mathrm{C}$ for the indicated times. Depending on themial treatment, material $\mathrm{C}-144$ can have either a negative expansion of $-550 \mathrm{AL} / \mathrm{L}$ from anbient to $1000^{\circ} \mathrm{C}$ or a near-zero expansion (C-144-1) as indicated in Figures 14 through 19. However, C-144 as a negative expansion material has better dimensional stability to both sulfuric acid and sodfum sulfate. Testing in this area will continue in Task $V$ by comparing the corrosion resistance of C-144 with the Corning 9460 AS heat exchange matertal.

Dimensional stability of the candidate materials to $1000^{\circ} \mathrm{C}$ and $1100^{\circ} \mathrm{C}$ is shown in Figures 20 and 21 , respectively. Materiais 9455, C-144, C-144-1 and C-145 ail have good dimenstonat stability of less than $2100 \mathrm{ppm} \Delta \mathrm{L} / \mathrm{L}$ at $1000^{\circ} \mathrm{C}$ for the indicated times, while materials 9455 and $C-745$ have better dimensional stabijity at $1100^{\circ} \mathrm{C}$ than naterial $\mathrm{C}-144$ which contracts about $300 \mathrm{ppm}$ aL/L after 10 hours while. matertals 9455 and $\mathrm{C}-745$ expand less than $40 \mathrm{ppm} \mathrm{aL} / \mathrm{L}$.

Elastic modu]us, modulus of rupture, and mercury porosinetry results are shom in Tables 6 and 7 , respectively. Thin wall $C-144$ and $C-145$ matrixes have tensile strengths of 465 psi with less than $5 \%$ wall porosity.

\section{I. Sulfuric Acid}

Honeycomb specimens were immersed in $1 \%$ sulfuric acid, evacuated to remove air from the passages, and removed from the acid after 2 hours. Excess actd was allowed to drain from the honeycomb by gravity before insecting then into a furnace at $300^{\circ} \mathrm{C}$ for 2 hours to complete one cycle. Figure 11 shows the dimensiona] changes $d L / L$ ppon after six exposure cycles.

Figure 12 shows the effect of a smaller acid concentration. In that excess acid was allowed to drain frow the honeyconb by gravity and then the matrix was shook twice which removed more acjd. Material $\mathrm{C}-145$ contracts with the weaker acid concentratjon, but expands by cracking with the more concentrated acid as a result of the $\mathrm{H}^{+}$for $\mathrm{Li}^{+}$ion exchange.

\subsection{Sodium Sulfate}

Minus 200 mesh reagent grade anhydrous sodiun sulfate was dusted through the honeycomb matrix passages of materials 9455 and $\mathrm{C}-145$ as evenly as possible until a spectmen weight gain of $1 / 4 \%$ was measured. The specimens were exposed to $1000^{\circ} \mathrm{C}$ for 24 hours to complete one cycle. Results for six cycles are shown in Figure.. 13 and tabulated in Table: 5 . Haterial $\mathrm{C}-744$ is two orders of magnitude better 
in dimensional stability to soditum sulfate than 9455 after six cycles while material $C-145$ is an order of magnitude better than 9455 after three cycles and about four times better after six exposure cycles.

Comparison of Ford data and owens-Illinois data vs. specimen cross sectiona] area as show in Table 5 indicates a large amount of variability in dimensional change with exposure cycle. Dusting the matrix does not give a uniform distribution of sodjum sulfate down the tube interior with majority of the sodium sulfate remaining near the specimens' ends producing large dimenstonal changes in honeycomb 9455 .

\subsection{Thenial Expansion}

The thermal expansion $\Delta L / L$ in ppm over the temperature range of ambient to $1000^{\circ} \mathrm{C}$ for materials $C-144, C-144-1, C-145$, and 9455 is shown in Figures 14 through 19 after exposure to $1000^{\circ} \mathrm{C}$ for $1,10,28,50,75$ and 100 hours, respectively. The standard deviation is $50 \mathrm{ppm} \Delta \mathrm{L} / \mathrm{L}$ for the three specimens measured.

The themal expansion specimens were cycled between ambient and $1000^{\circ} \mathrm{C}$ according to the following schedule:

1. ten cycles with 1 hour hold at $1000^{\circ} \mathrm{C}$

2. three cycles with a 6 hour hold at $1000^{\circ} \mathrm{C}$

3. one cycle with a 22 hour hold at $1000^{\circ} \mathrm{C}$

4. two cycles with a 25 hour hold at $1000^{\circ} \mathrm{C}$

Thermial expansion was measured after exposure times at $1000^{\circ} \mathrm{C}$ for $1,10,28,50$, 75 and 100 hours. The specimen length is ineasured before and after each thermal exposure. Figure 20 shows the specimen length change ( $\Delta \mathrm{L} / \mathrm{L} \mathrm{ppm})$ atter thenma) exposure.

\subsection{Thermal Phase Stability}

Thermal phase stability at $1100^{\circ} \mathrm{C}$ for $9455, \mathrm{C}-144$ and $\mathrm{C}-145$ has been analyzed by $X$-ray diffraction. Corning honeycomb $9455, \mathrm{C}-144$ and $\mathrm{C}-145$ are stable for the 10 exposure cycles, ambient to $1100^{\circ} \mathrm{C}$ with a one hour hold for each cycle. Dimensional stability at $1700^{\circ} \mathrm{C}$ is shown in Figure 21 for naterfals $9455, \mathrm{C}-144$ and $\mathrm{C}-145$.

\subsection{Elastic Modulus and Modulus of Rupture}

Modulus of rupture values shown in Table 6 were obtained using four-point flexure. The outer knife edge span was $8.9 \mathrm{cms}$ and the jnner span was $1.9 \mathrm{~cm}$. Specimen dimensions were $11.4 \times 1.9 \times 1.3 \mathrm{cas}$ with the $11.4 \times 1.9 \mathrm{~cm}$ surface as the tensile surface. Stress rates were $700 \mathrm{kPa}$ per ain. for tangential 9455 matrix and $200 \mathrm{KPa}$ per min. for radial 9455 matrix and isotropic matrixes C-144 and $C-145$. Matrixes $C-144$ and $C-145$ have a high open frontal area of $85 \%$ conh pared to 9455 matrix which has $65 \%$ open frontal area. The lower strength values of approximately $450 \mathrm{kPa}$ for $\mathrm{C}-144$ and $\mathrm{C}-145$. compared to 9455 matrix strengths of 
$1790 \mathrm{KPa}$ (radial) and $4830 \mathrm{KPa}$ (tangential) is attributed to the thinner 50 unt matrix wall thickness of $\mathrm{C}-144$ and $\mathrm{C}-145$ compared to the 130 to $305 \mathrm{um}$ wall of matrix 9455.

Elastic modulus values shown in Table 6 were obtained using the sonic resonance technique according to ASTM 5tandard C623-69T. These are tentative values since we have obtained the same published value for 9455 tangential specintens but are one order in magnitude higher for 9455 radial specimens. This discrepancy is due to matrix wall and vold configuration which effect the ability to determine the resonance frequency. Strain gages $w 111$ be used in future testing to determine the elastic modulus.

\subsection{Microstructure and Porosity}

Electron micrographs of solid materials 1 and 2 and matrix materials C-144 and C-145 are shown in Figure 22. Materials 2, C-144 and C-145 all have grain sizes less than 1 um. Material 1 has a 2-1/2 um grain size.

Mercury porosimetry results for matrix materia]s $\mathrm{C}-144, \mathrm{C}-145$, and 9455 are show in Table 7.

Matrix C-145 has a calculated wall porosity of $5 \%$; however, matrix $\mathrm{C}-145$ has a near hexagonal cross section but at tube interstices a 50 um dia. open area exists where the two glass tube walls did not bloat together. This open area may account for the $52 \mu$ average dia. pore reported from mercury porosimetry. Because this open interstitial area influences the displacement density, a higher wajl porosity is calculated than what is actually present. Matrix C-144 has a binodal distribution of voids, $20 \mu \mathrm{m}$ average dia. voids which may be because of the interstitíal area between tubes and $0.01 \mu \mathrm{m}$ average dia. voids in the tube walls as a result of leaching lithium from the material. The wall porosity will be investigated further for matrixes $[-144$ and $[-145$ after stuffing material has been added to the glass tube bloating process or other techniques are used to eliminate the open interstitial area. The interstitial area is not desirable from a seal bar wear standpoint because a single wall rather than a double watt thickness is present.

\section{Conclusions}

This investigation evaluated four glass-ceramic materials suitable for use as gas turbine heat exchangers. The purpose of the program was to develop improved corrasion resistant materials less susceptible to attack by sulfuric acid and sodium salts. Comparative tests of the new improved materials fabricated as solid and honeyconb matrix were made with 1st generation lithium aluminosilicate (LAS) Corning solid 9454 and heat exchanger matrix 9455 .

Two of the glass-ceramic materials, $\mathrm{C}-144$ and $\mathrm{C}-145$, have superior durability towards sulfuric acid and sodium sulfate compared to Corning materials 9454 and 9455. Material C-144 is a leached LAS material whose major crystalline phase is silica keatite plus mullite. Material C-145 is composed of LAS keatite solid solution. 
1. Material C-144 is two orders of magnitude better in dimensional stability to sulfuric acid at $300^{\circ} \mathrm{C}$, and one order of magnitude better in stability to sodium sulfate at $1000^{\circ} \mathrm{C}$ compared to material 9455 .

2. Material $\mathrm{C}-145$ is initially two times better in stability to sulfuric acid at $300^{\circ} \mathrm{C}$ and about one order of magnitude better in stability to sodium sulfate at $1000^{\circ} \mathrm{C}$ compared to material 9455 .

3. Materials $\mathrm{C}-144$ and $\mathrm{C}-\mathrm{T45}$ are either better than or comparable to material 9455 in physical properties. Matertals $\mathrm{C}-144$ and $\mathrm{C}-145$ have Tess than $300 \mathrm{ppm} \Delta \mathrm{L} / \mathrm{L}$ thernal expansion from ambient to $1000^{\circ} \mathrm{C}$, good dimensional stability of less than $\approx 100 \mathrm{ppm} \mathrm{AL} / \mathrm{L}$ change in length after exposure to $1000^{\circ} \mathrm{C}$ for 100 hours and acceptable dimensional stability to short exposure times at $1100^{\circ} \mathrm{C}$. Material $\mathrm{C}-145$ expands less than $40 \mathrm{ppm} \Delta \mathrm{L} / \mathrm{L}$ after $1100^{\circ} \mathrm{C}$ for 10 hours while material $\mathrm{C}-144$ contracts about $300 \mathrm{ppm}$ $\Delta L / L$. Material 9455 has a $500 \mathrm{ppm} \Delta \mathrm{L} / \mathrm{L}$ thermal expansion from ambient to $1000^{\circ} \mathrm{C}$, good dimensional stability of less than $\approx 100 \mathrm{ppm}$ change in length after $1000^{\circ} \mathrm{C}$ for 100 hours, and has adequate dimensional stability at $1100^{\circ} \mathrm{C}$ expanding less than $40 \mathrm{ppm} \Delta \mathrm{L} / \mathrm{L}$ change in Tength after 10 hours.

4. The glass-ceramtc fabrication process of $\mathrm{C}-144$ and $\mathrm{C}-145$ produced a hexagonal honeycomb matrix with a very thin wall thickness of $50 \mathrm{um}$, a very high open frantal area of $85 \%$, and a wall porosity of less than 5\%. Because of the thin walls and high open frontal area, matrix honeycomb $\mathrm{C}-144$ and $\mathrm{C}-145$ have a lower tensile strength perpendicular to the open passages than material 9455 . Honeycomb $\mathrm{C}-\mathrm{T} 44$ and $\mathrm{C}-145$ have isotropic structures with tensile strengths of $450 \mathrm{KPa}$ compared to the anisotropic structure of 9455 matrix which has a tensile strength of $1800 \mathrm{KPa}$ in the radial direction and $4800 \mathrm{KPa}$ in the tangential direction. The wall thickness of the 9455 matrix varies between 130 to $305 \mu \mathrm{m}$. 
Table l - Depth of Sulfuric Acid Reaction (in millimeters)

\begin{tabular}{|c|c|c|c|c|c|c|}
\hline $\begin{array}{l}\mathrm{H}_{2} \mathrm{SO}_{4} \text { at } \\
300^{\circ} \mathrm{C} \text { for }\end{array}$ & $\underline{9454}$ & 1 & 2 & C-144 & 4 & $\mathrm{C}-145$ \\
\hline 6 hours & 0.995 & 0.147 & 0.035 & $\begin{array}{c}\text { none } \\
\text { detected }\end{array}$ & 0.227 & 0,083 \\
\hline 16 hours & 2.13 & 0.233 & 0.089 & n & 0.306 & 0.164 \\
\hline 32 hours & 3.38 & 0.270 & 0.161 & $"$ & 0.390 & 0.215 \\
\hline 48 hours & 4.77 & 0.292 & 0.198 & $\mu$ & 0.443 & 0.224 \\
\hline 64 hours & 5.27 & 0.323 & 0.205 & $"$ & 0.482 & 0.265 \\
\hline 80 hours & 6.40 & 0.420 & 0.237 & " & 0.544 & 0.310 \\
\hline
\end{tabular}

Table 2 - Depth of Sodium Sulfate Reaction (um)

$\mathrm{Na}_{2} \mathrm{SO}_{4}$ at

$1000^{\circ} \mathrm{C}$ for

24 hours

D Cristobalite

1 Cycle

45

2 cycles

100

155

3 cycles

4 Cycles

200

205

230 $\underline{9454}$

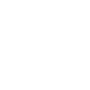

2055

$90 \quad 30 \quad 0$

$100 \quad 45 \quad 0$

$100 \quad 65$

13590

$205 \quad 130$ 0
C-144

Heat Treatment Temperature $\left({ }^{\circ} \mathrm{C}\right)$ $1150-1 \mathrm{hr} \quad 1200-\mathrm{hhr} 1200=16 \mathrm{hrs}$ C-145 D 510 5 10 0 -... -.10 150

550200

750

N

1000

N

N

* * of cristobalite detected as a function of depth measured from the specimen surface

** $M$ - No reaction detected by $X$-ray diffraction

** Sixth cycle was not completed because bulk specimens greater than $\approx 1$ mom were not obtained because of cracking in leaching ifthta from the LAS material 
Jable 3 - Young's Modulus

\begin{tabular}{|c|c|c|c|}
\hline & $\mathrm{KPa} \times 10^{-56}$ & $\begin{array}{l}\text { Modulus } \\
\left(\text { Psi } \times 10^{-6}\right)\end{array}$ & $\begin{array}{c}\text { Poisson's } \\
\text { Ratio } \\
\end{array}$ \\
\hline Material 1 & 91.57 & $(13.28)$ & 0.23 \\
\hline Material 2 & 76.12 & $(11.04)$ & 0.25 \\
\hline Material C-144 & -- & & -- \\
\hline Material 4 & 77.43 & (11.23) & 0.23 \\
\hline Material C-145 & 80.95 & (11.74) & 0.26 \\
\hline Materia] 9454 & 73.64 & $(10.68)$ & 0.28 \\
\hline
\end{tabular}

Table 4 - Modulus of Rupture

\begin{tabular}{|c|c|c|c|c|c|c|c|}
\hline \multirow[b]{2}{*}{ Material } & \multicolumn{2}{|c|}{$\begin{array}{l}\text { Modulus of Rupture } \\
\text { Strength }\end{array}$} & \multicolumn{2}{|c|}{ Std. Deviation } & \multirow[b]{2}{*}{$\begin{array}{c}\text { Time to Failure } \\
\text { (sec.) }\end{array}$} & \multicolumn{2}{|c|}{ Load } \\
\hline & $\frac{\text { Str }}{\mathrm{xpa}}$ & $\frac{\text { ugth }}{(\mathrm{Ps} i)}$ & $\mathrm{KPa}$ & (Ps:1) & & kgs. & (1bs.) \\
\hline 9454 & 69.600 & $(10,100)$ & 5,500 & $(800)$ & 27 & 204 & $(450)$ \\
\hline 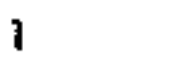 & 93,800 & $(13,600)$ & 5,500 & $(800)$ & $3]$ & 259 & $(570)$ \\
\hline 2 & 90,300 & $(13,100)$ & 6,900 & $(1000)$ & 27 & 247 & $(545)$ \\
\hline C-144 & - & -- & -- & -- & - & 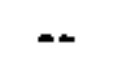 & -- \\
\hline 4 & 38,600 & $(5,600)$ & 1,700 & $(1700)$ & 16 & 120 & $(265)$ \\
\hline$C-745$ & 104,100 & $(15,100)$ & 8,300 & $(1200)$ & 31 & 308 & $(680)$ \\
\hline
\end{tabular}


Table 5 - Dimensional Stability $\mathrm{AL} / \mathrm{L}$ ppm to Sodfum Sulfate at $1000^{\circ} \mathrm{C}$ for $24 \mathrm{Hr}$. Cycles Us. Specimen Cross Sectional Area

\begin{tabular}{|c|c|c|c|c|c|}
\hline 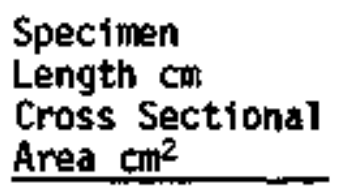 & Ford Data* & $\begin{array}{l}9455 \\
6.9 \\
1.6 \\
\end{array}$ & $\begin{array}{l}9455 \\
6.9 \\
4.5 \\
\end{array}$ & $\begin{array}{l}C-144 \\
6.9 \\
4.8 \\
\end{array}$ & $\begin{array}{l}C-145 \\
6.9 \\
4.8 \\
\end{array}$ \\
\hline Cycle & & & & & \\
\hline 1 & 175 & 2070 & 250 & -95 & 30 \\
\hline 2 & 400 & 2930 & 1800 & -170 & 180 \\
\hline 3 & 700 & -- & 2200 & -135 & 390 \\
\hline 4 & 1250 & -- & 2550 & -170 & 490 \\
\hline 5 & 1575 & -- & 2830 & -195 & 625 \\
\hline 6 & -- & -- & 2990 & -200 & 750 \\
\hline
\end{tabular}

*C00-2630-15, Ford Progress Report, April 1976, "Automotive Gas Turbine Ceramic Regenerator Design and Reiliability Program."

Table 6 - Modulus of Rupture and Elastic Modulus

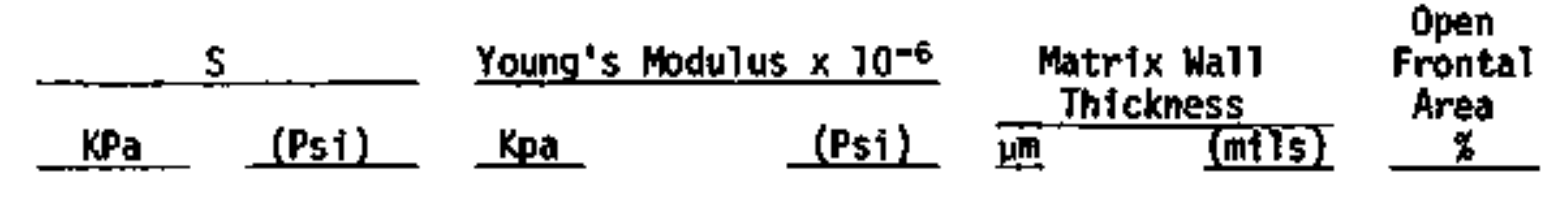

$\underline{9455}$

Solid

$$
68,950 \quad(10,000) \quad 73.64
$$

Matrix

Radial

1,800

(260) 7.6

Tangential

4,800

(700) 13.8

$(2.0)$

$127-305 \quad(5-12)$

65

$\underline{C-144}$

Solid

Matrix

410

(60) 1.0

(0.15)

50

(2)

85

C- 145

Solid

$104,100 \quad(15,100) \cdot 80.94$

(11.74)

Matrix

480

(70) 1.2

$(0.18)$

50

(2)

85 


\section{Table 7 - Matrix Porosity}

\begin{tabular}{|c|c|c|c|c|c|}
\hline Matrix & $\begin{array}{l}\text { Net Pore Vol. } \\
\text { (cc/g) }\end{array}$ & $\begin{array}{l}\text { Aveg. Pore Dia. } \\
\text { (هي) }\end{array}$ & Buk & $\begin{array}{l}\text { Density (gm/cc) } \\
\text { Dispiacement }\end{array}$ & \$keletal \\
\hline 9455 & 0.03362 & 7.4 & .74 & $2.08 *$ & $2.28^{*}$ \\
\hline$C-144$ & 0.02898 & 0.01 & .40 & -- & -- \\
\hline$C-145$ & 0.02188 & 52 & .37 & 2.52 & 2.39 \\
\hline
\end{tabular}


SULFURIC ACID

$80 \mathrm{hr} 300^{\circ} \mathrm{C}$

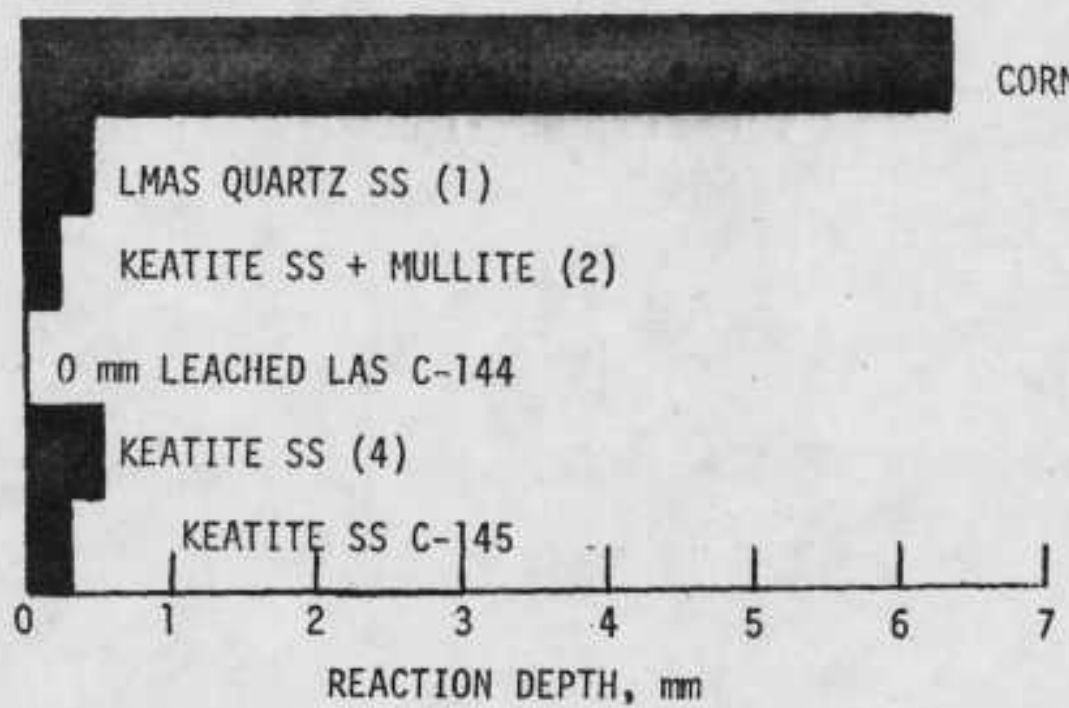

Figure 1 - Reaction Depth after 80 Hrs. of $300^{\circ} \mathrm{C}$ Sulfuric Acid 
SODIUM SULFATE SIX $24 \mathrm{hr}$ CYCLES AT $1000^{\circ} \mathrm{C}$

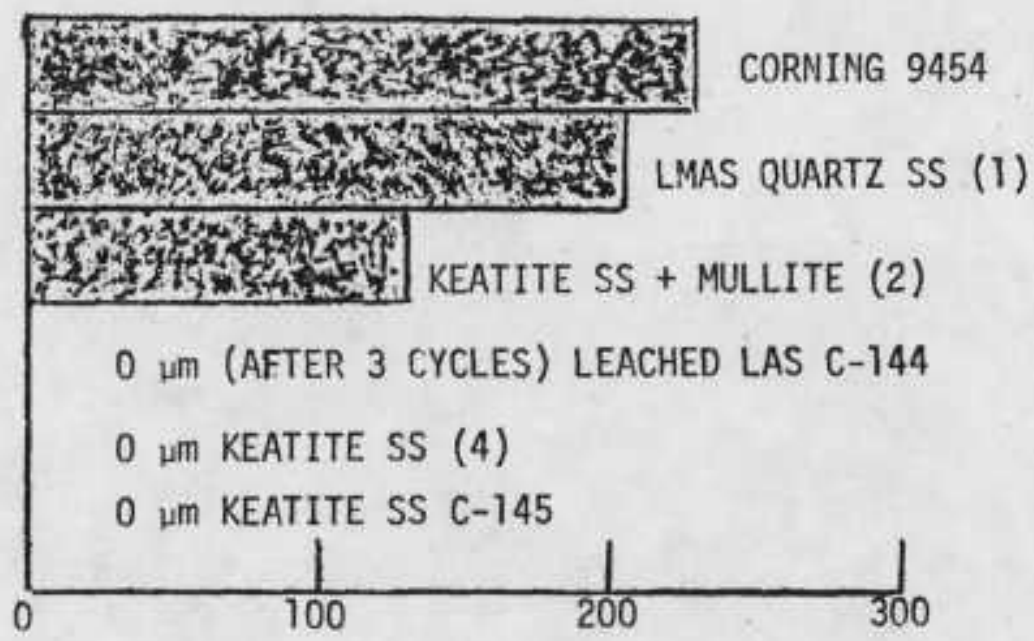

Figure 2 - Reaction Depth After Six $24 \mathrm{Hr}$ Cycles of Sodium Sulfate at $1000^{\circ} \mathrm{C}$ 


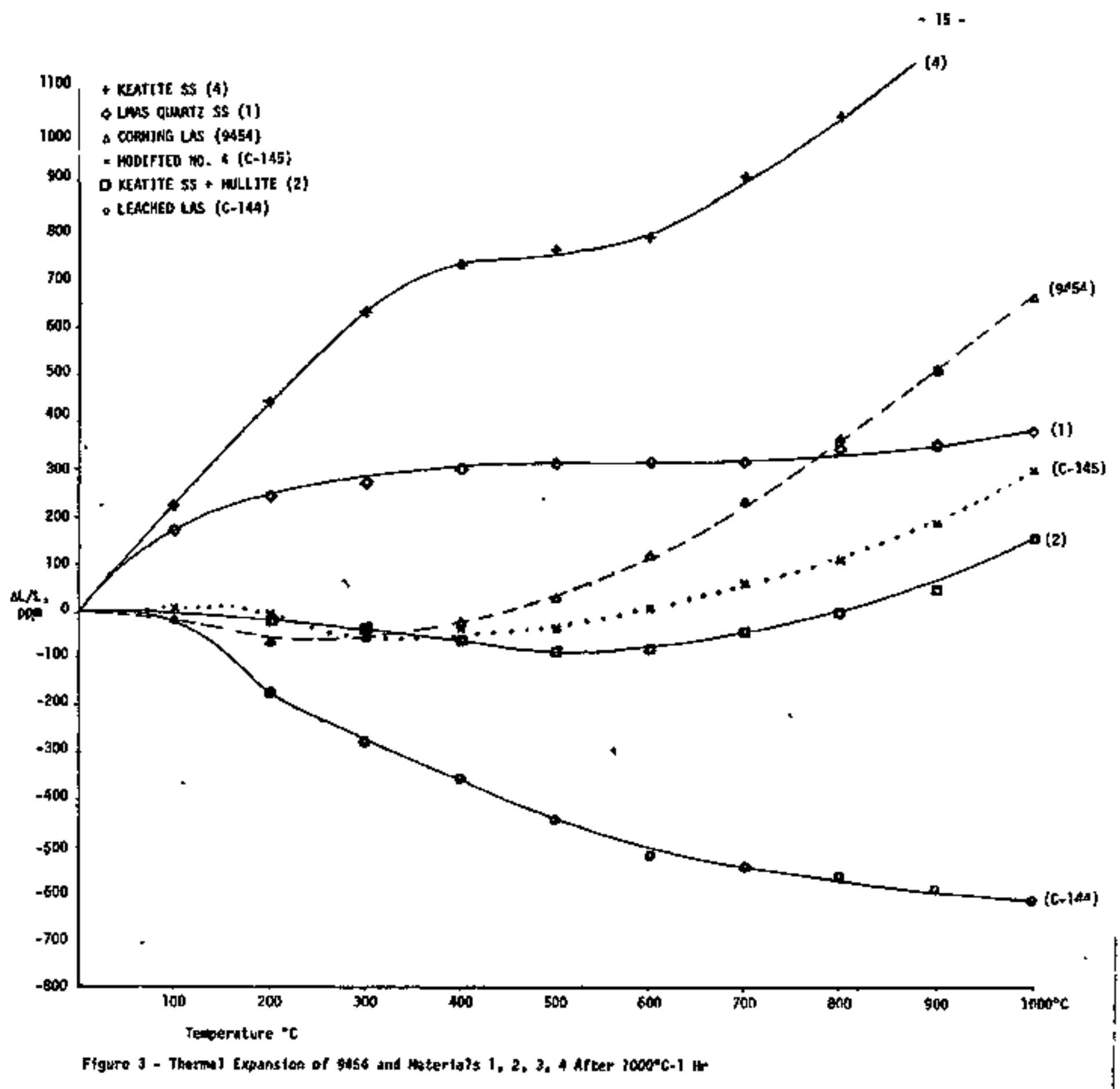




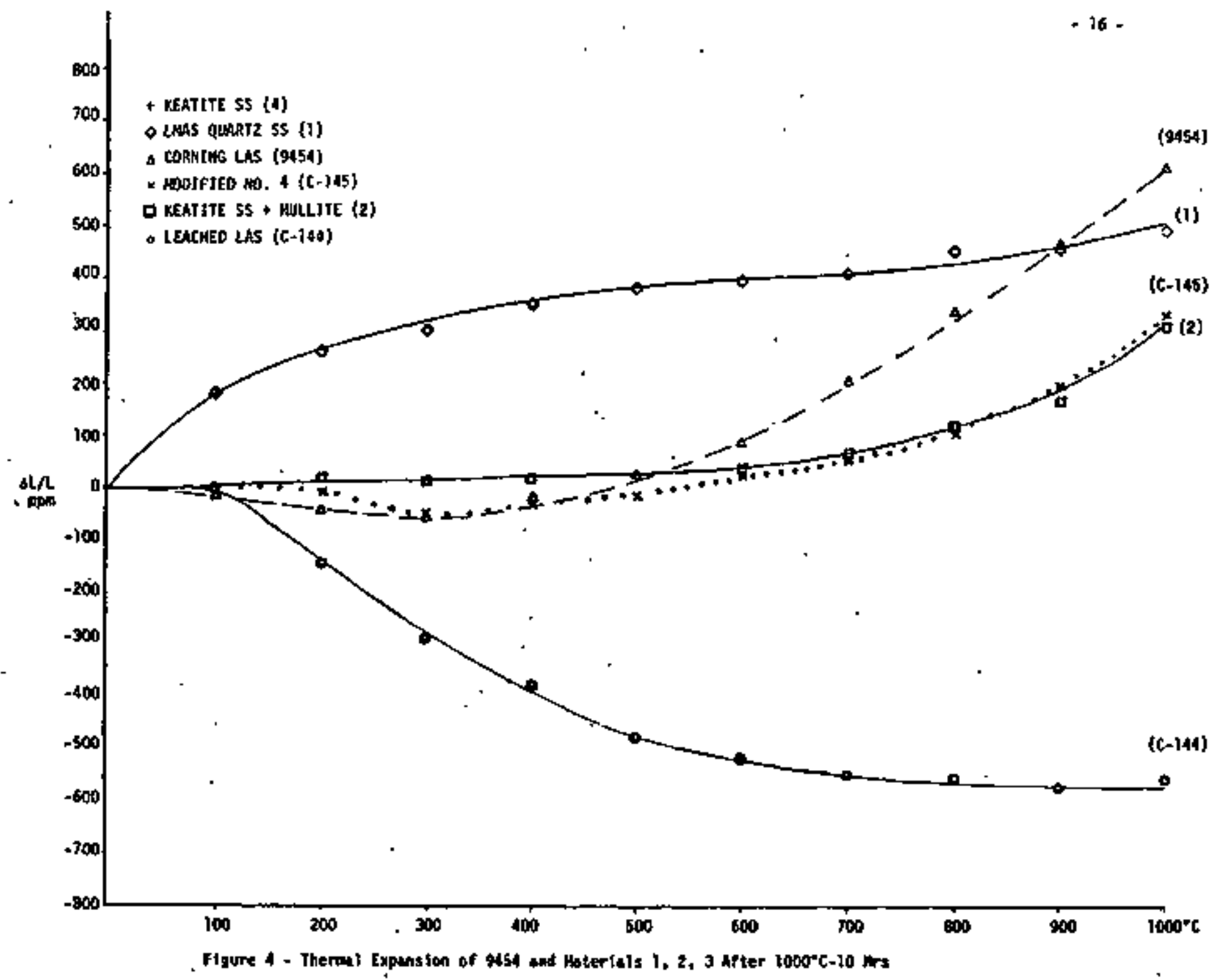




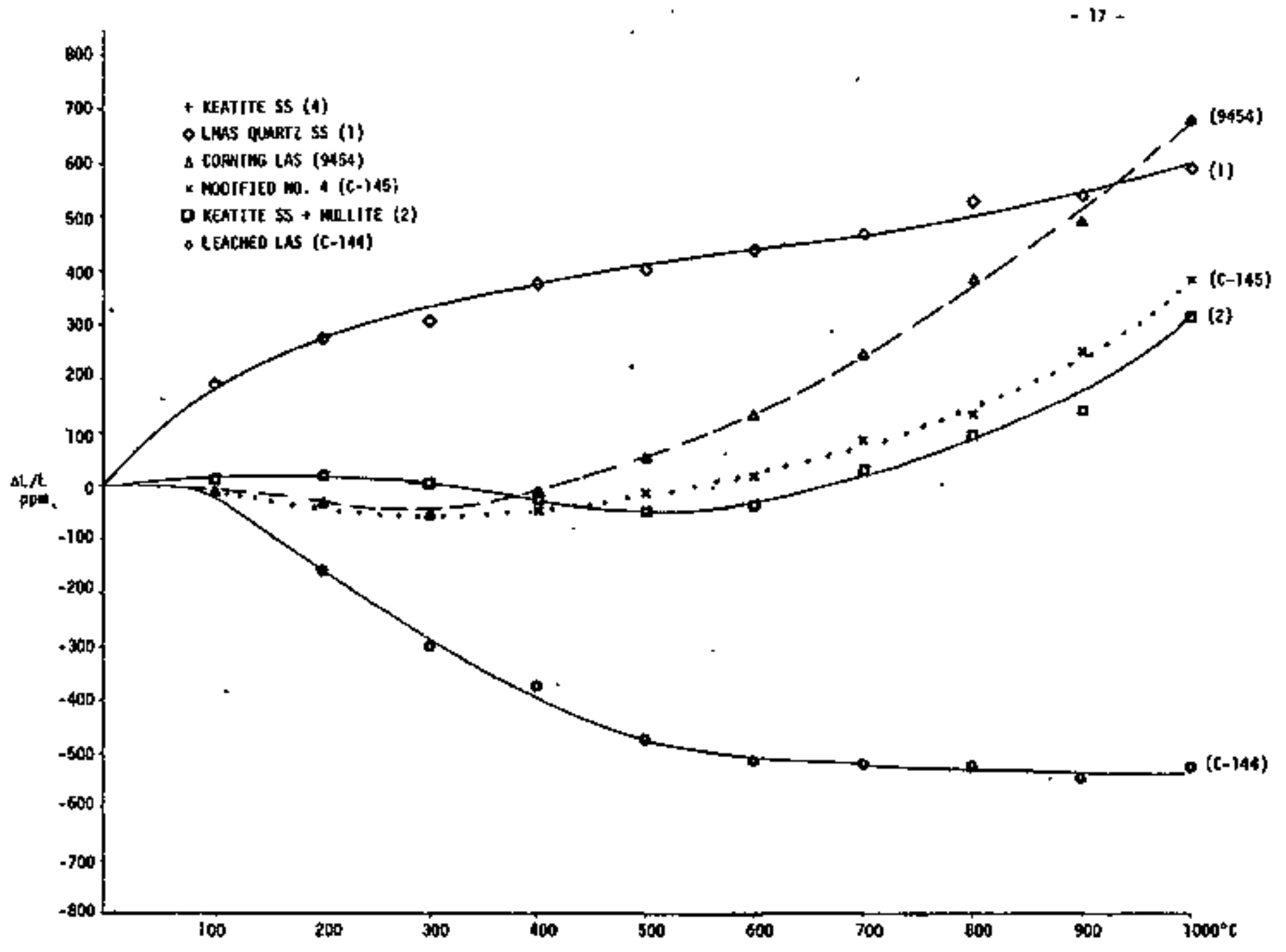

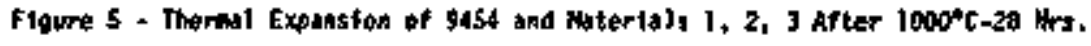




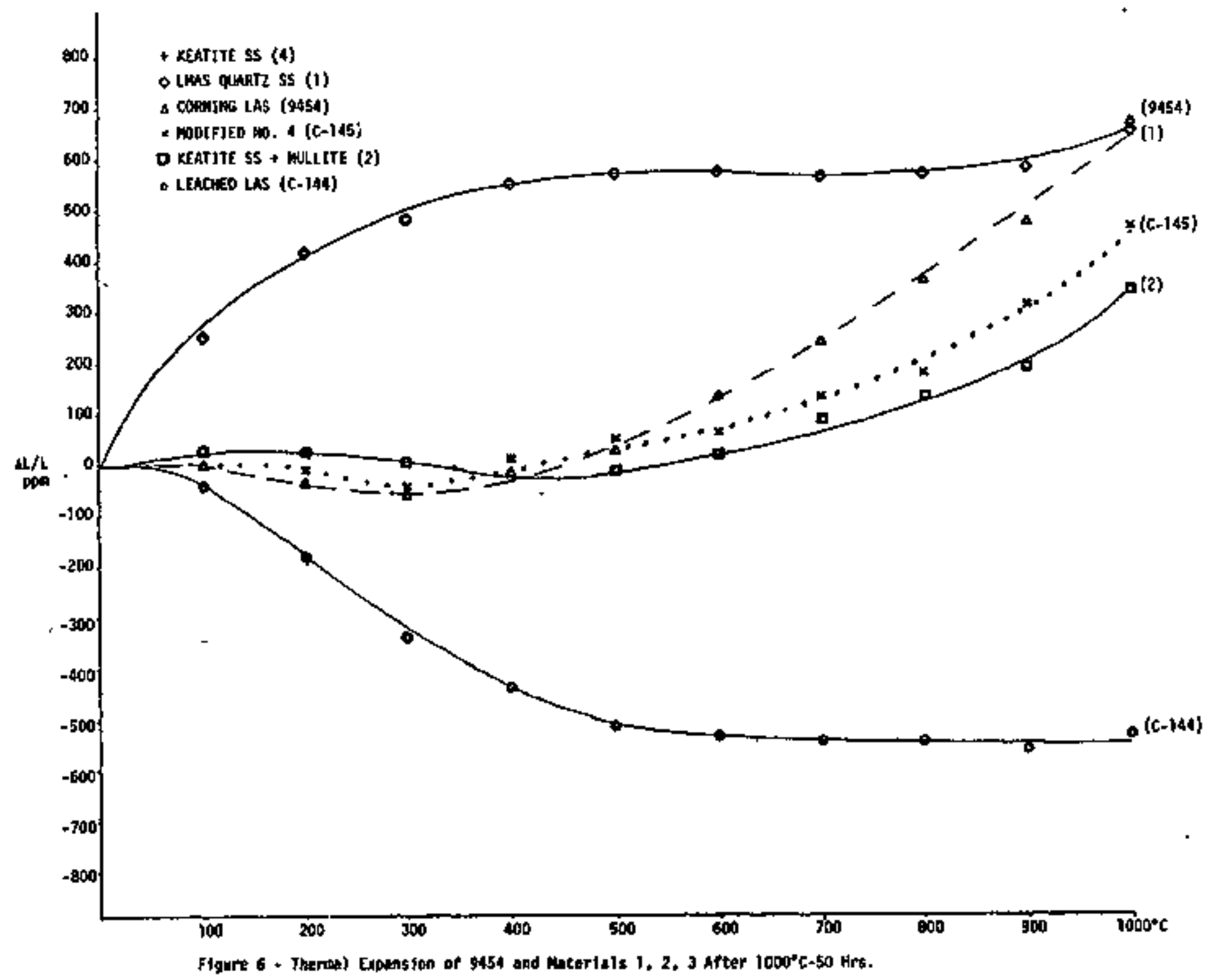




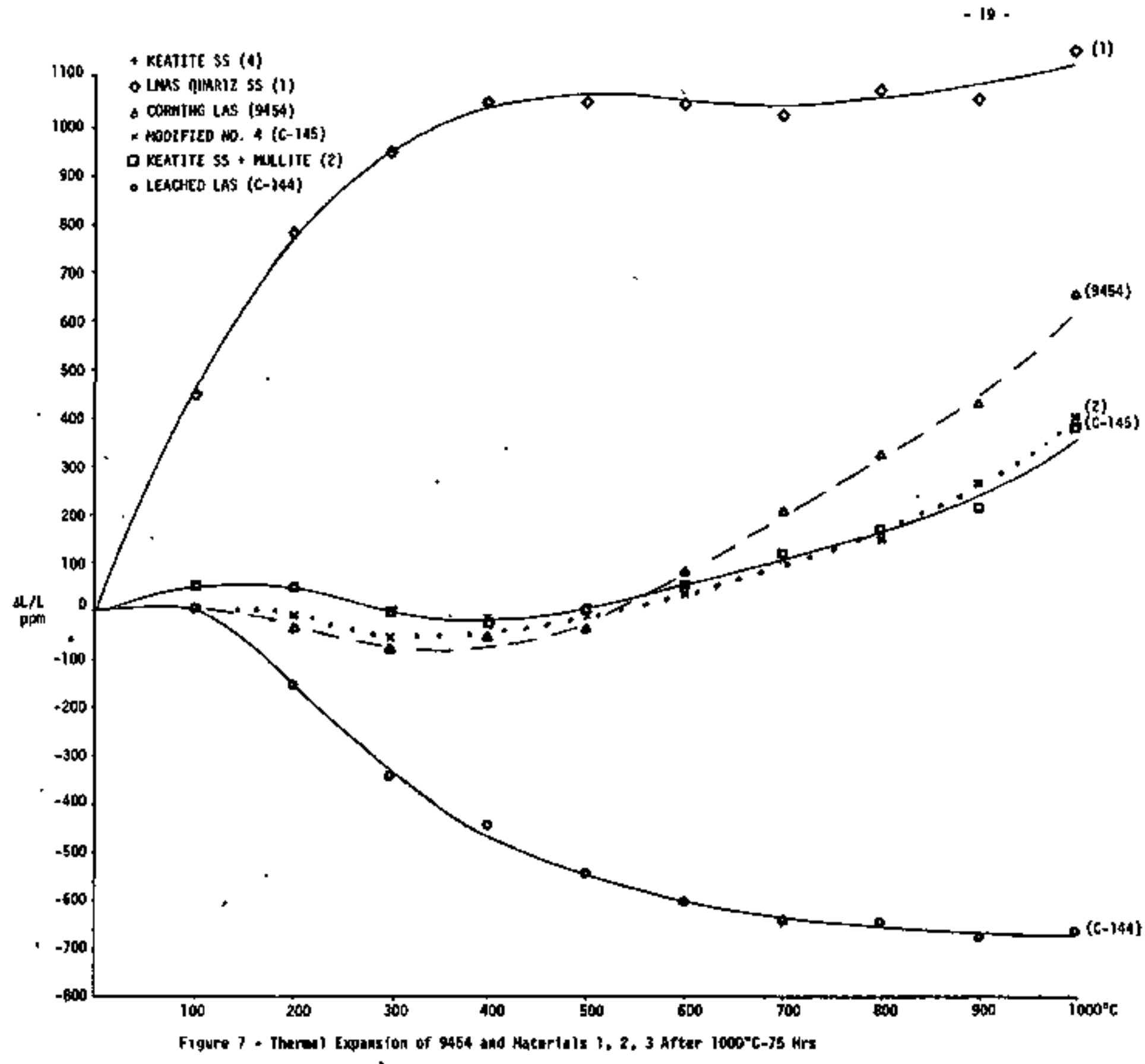




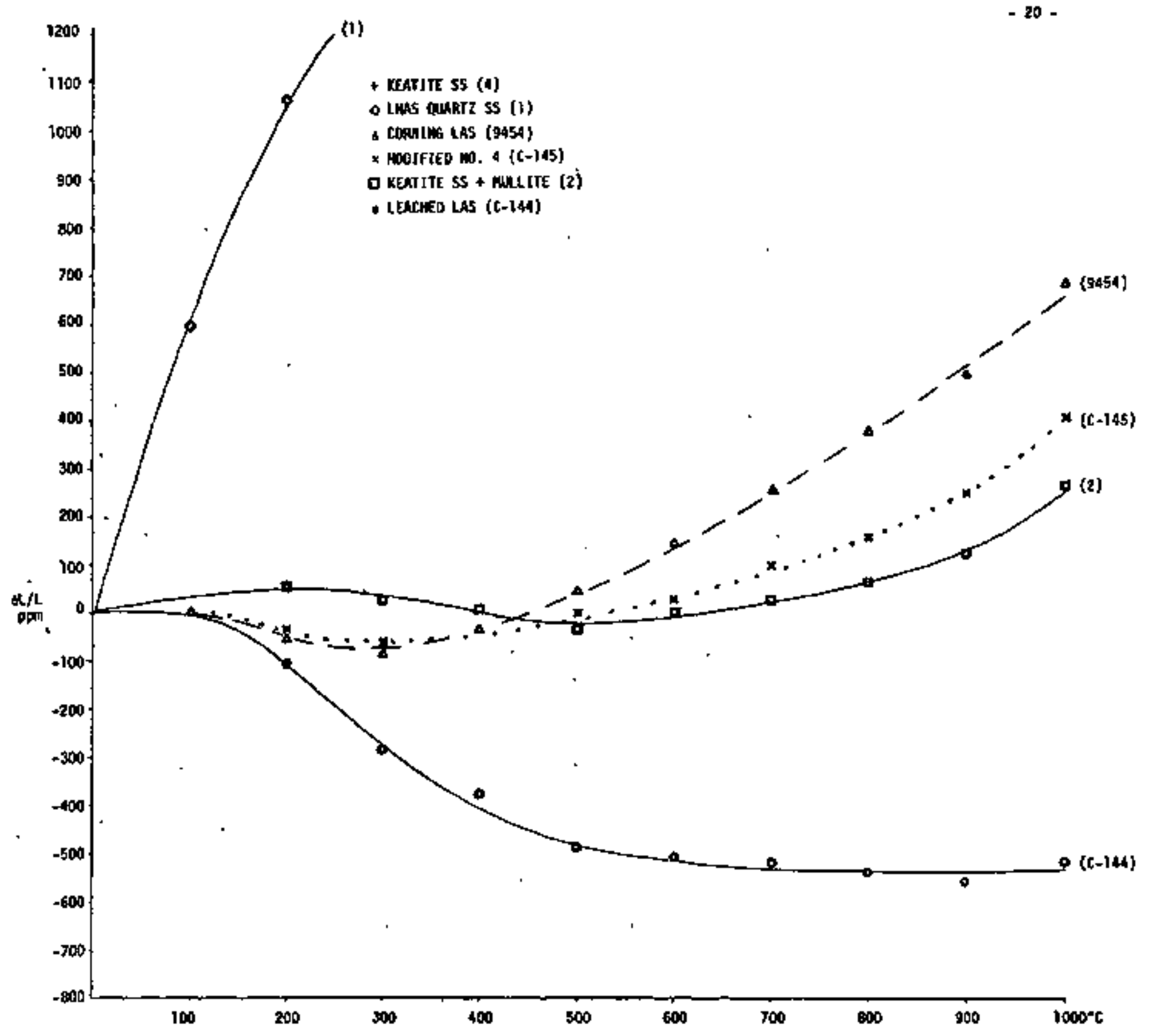

Figure 8 - Theral Expansion of 945t and keterials 1, 2, 3 After $1000^{\circ} \mathrm{C}-1000$ Mrs 


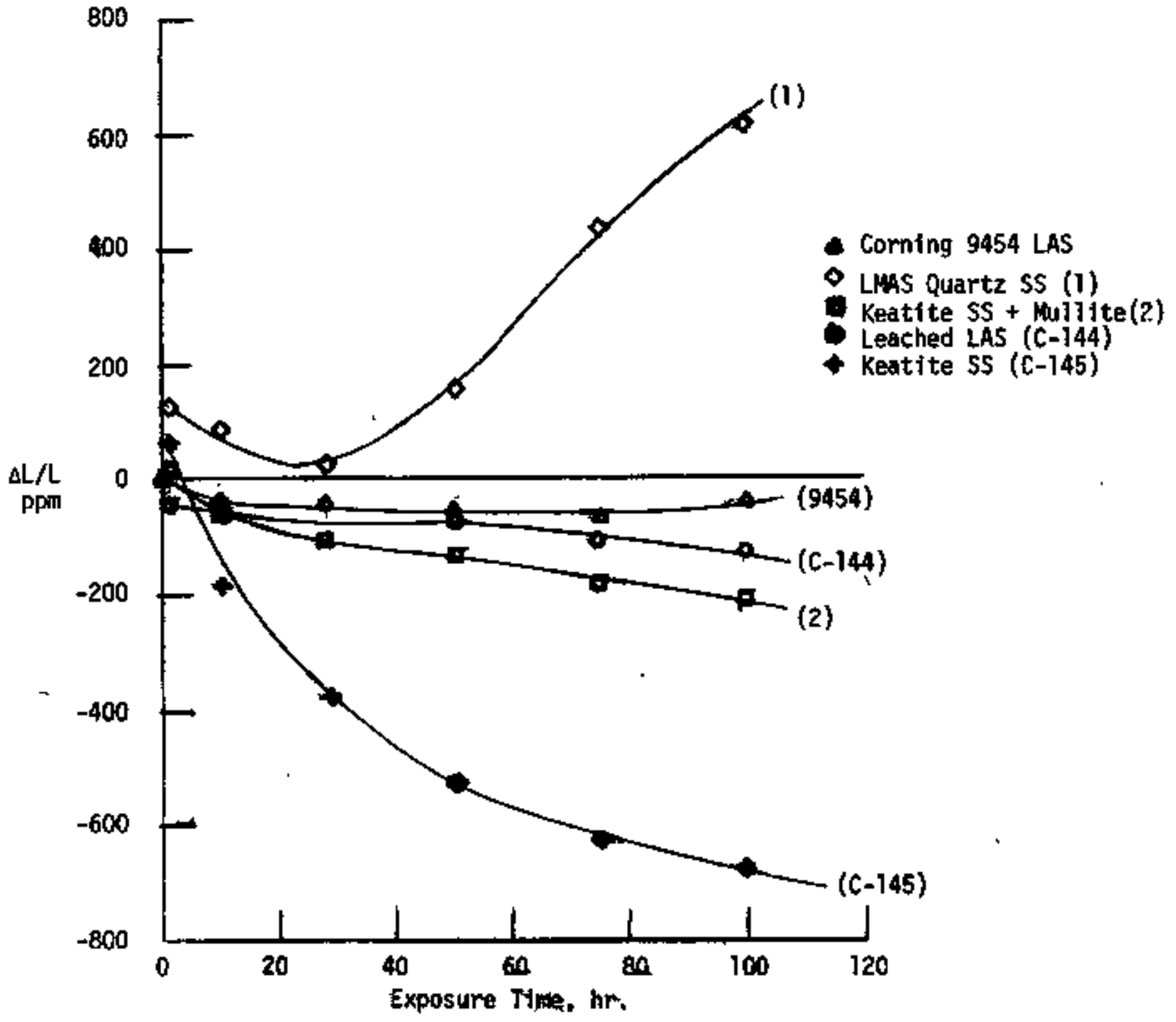

Figure 9 ajmensjonal Stabitity at $1000^{\circ} \mathrm{C}$, Length Change after Exposure 


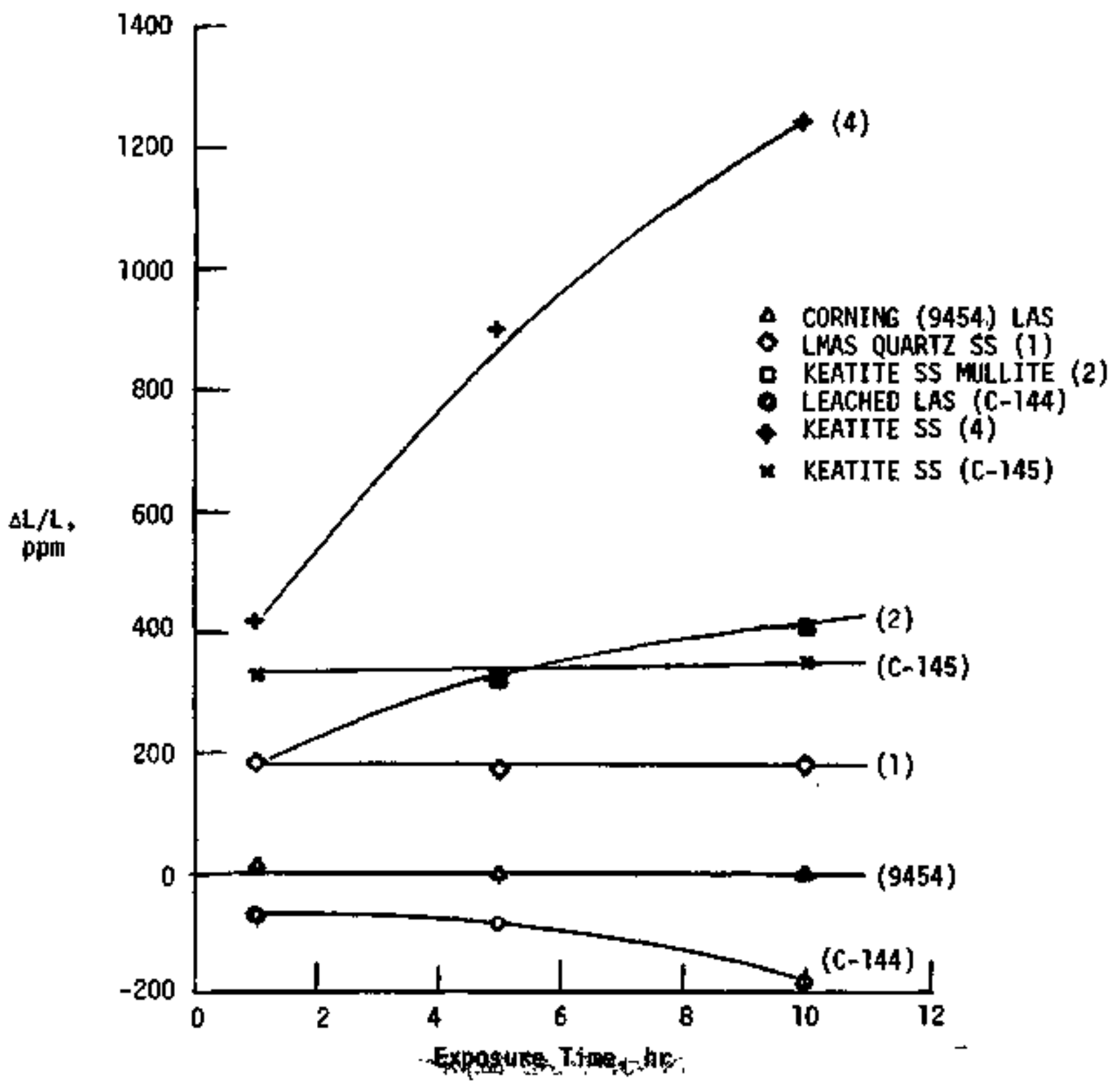

Figure 10 - Dimiensionar Stability at $1100^{\circ} \mathrm{C}$, Length Change After Exposure 


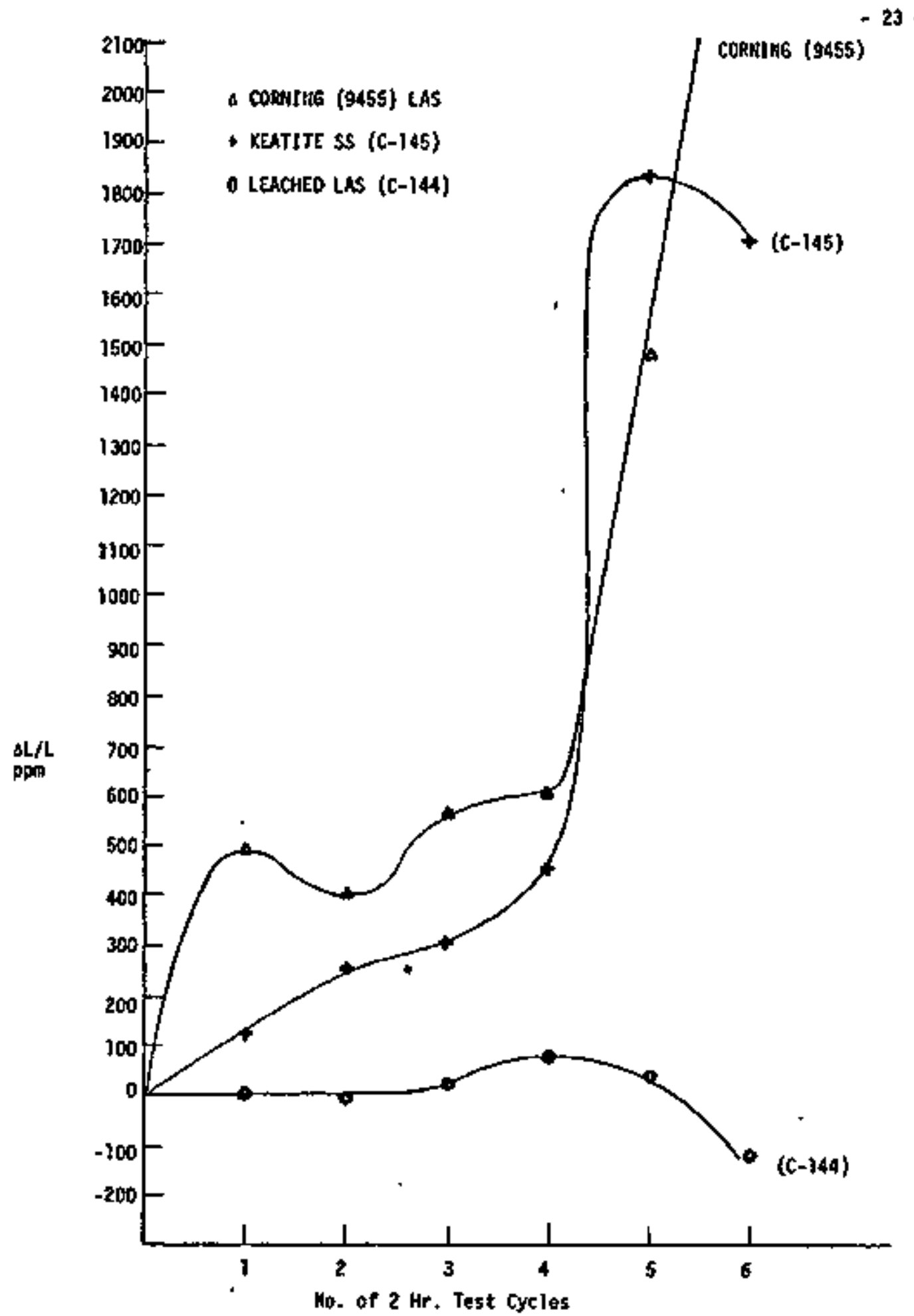

Figure 19 - Matrix Dransion Stability to $300^{\circ} \mathrm{C}$ Sulfuric Acid.

Nethod $\mathrm{l}$ - Acid Drained by Gravity with no Shaking. 


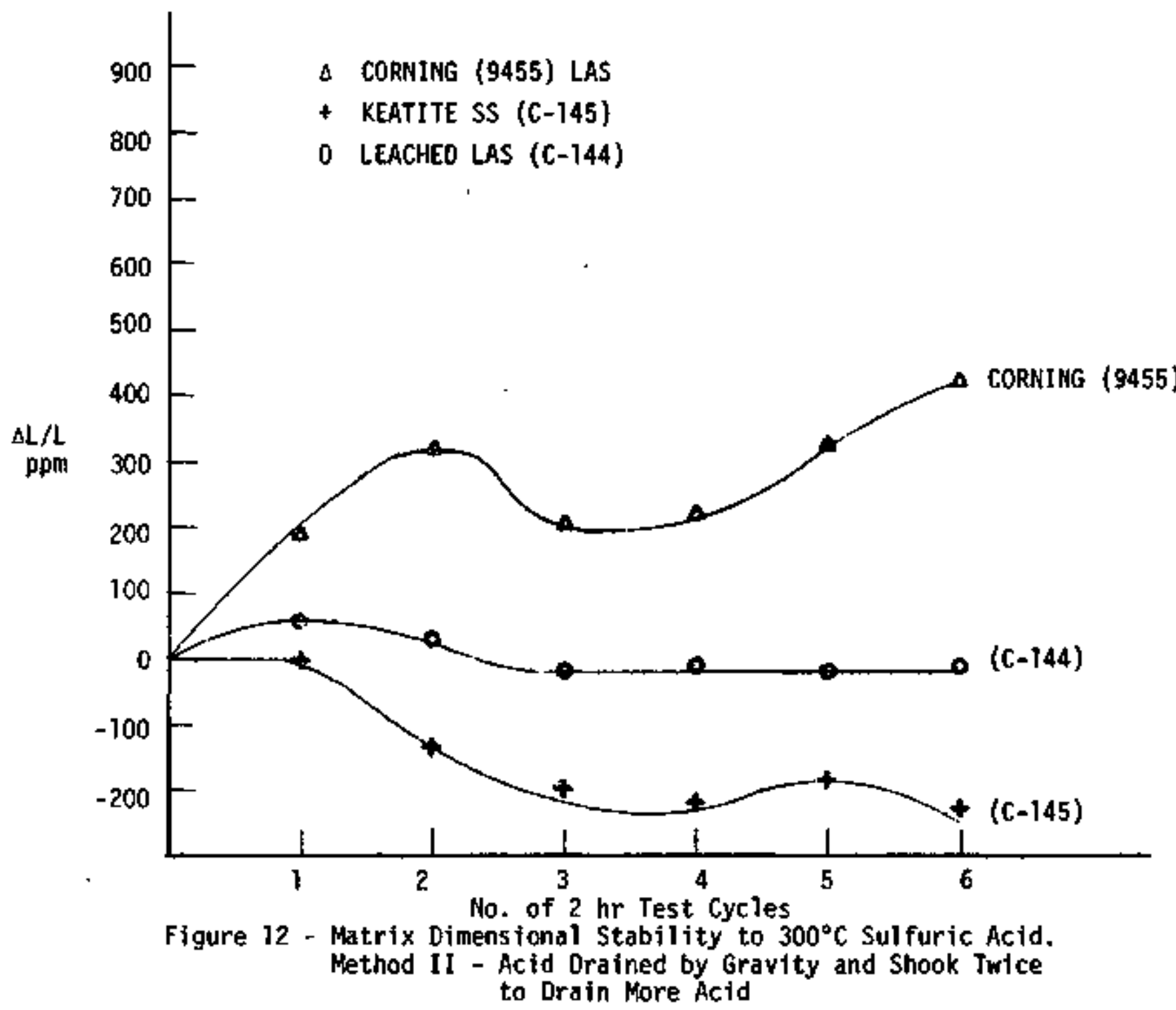




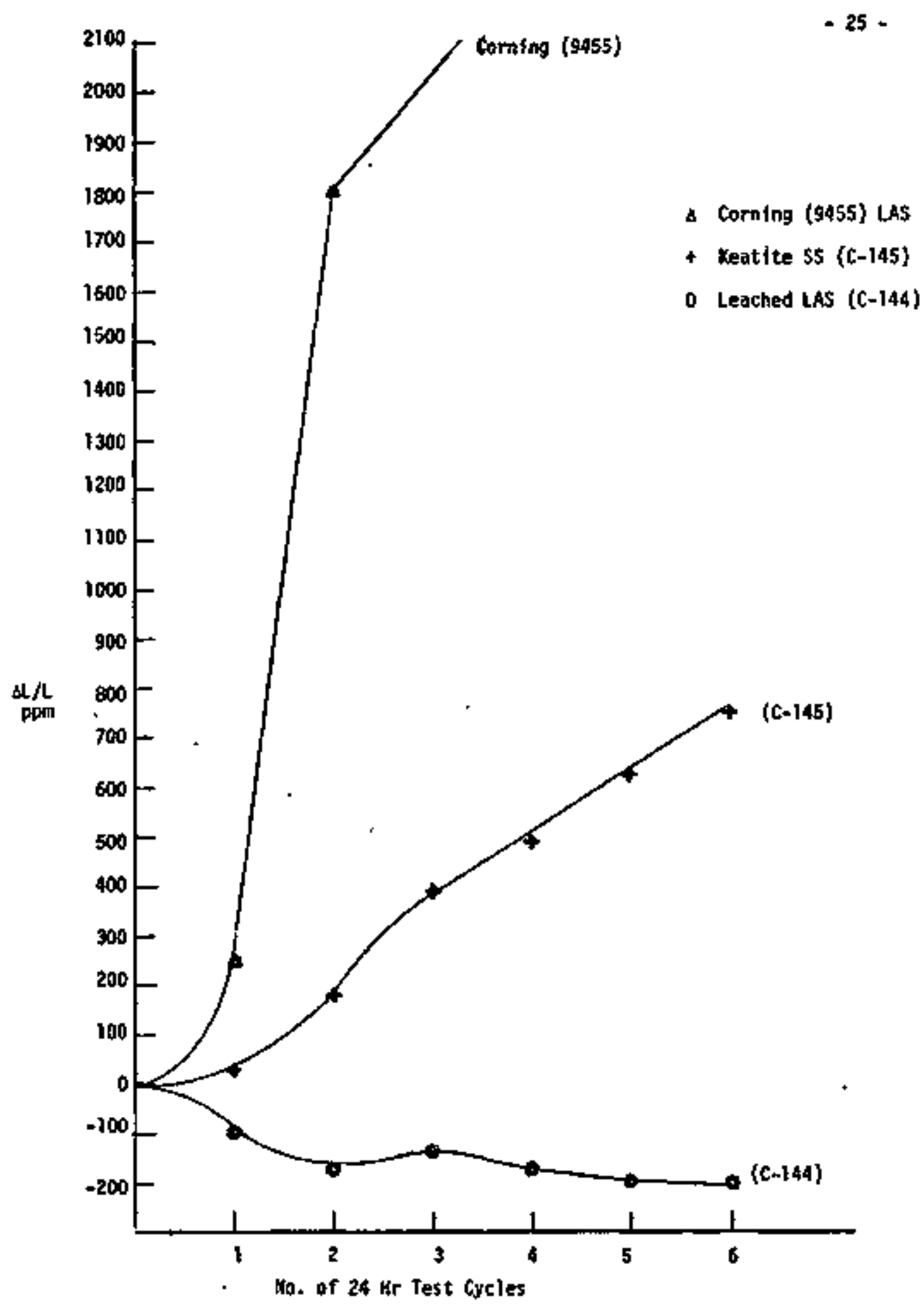

.Figure 13 - Matrix Dimensional Stability to $1000^{\circ} \mathrm{C}$ Sodiua Sulfate 


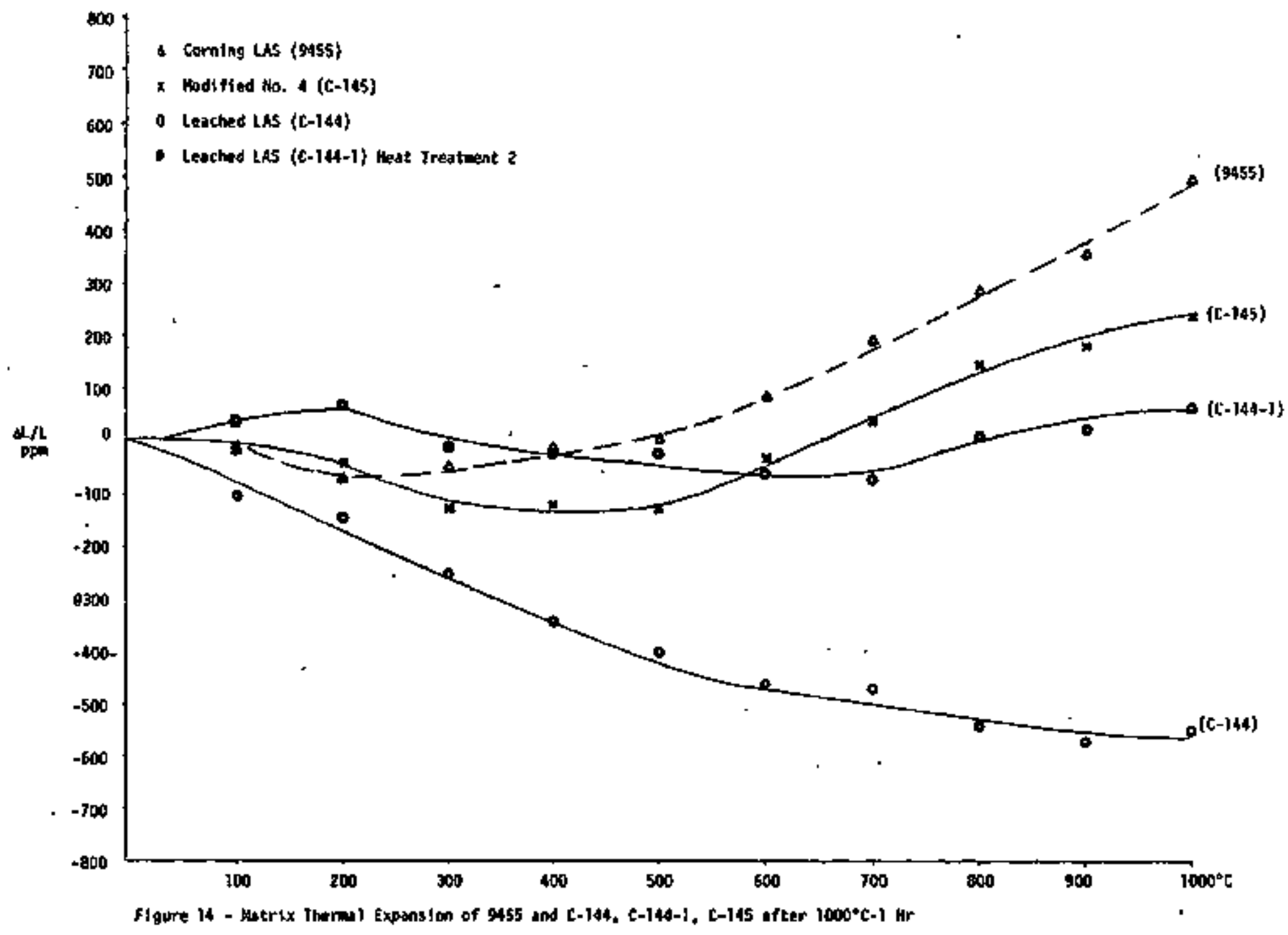




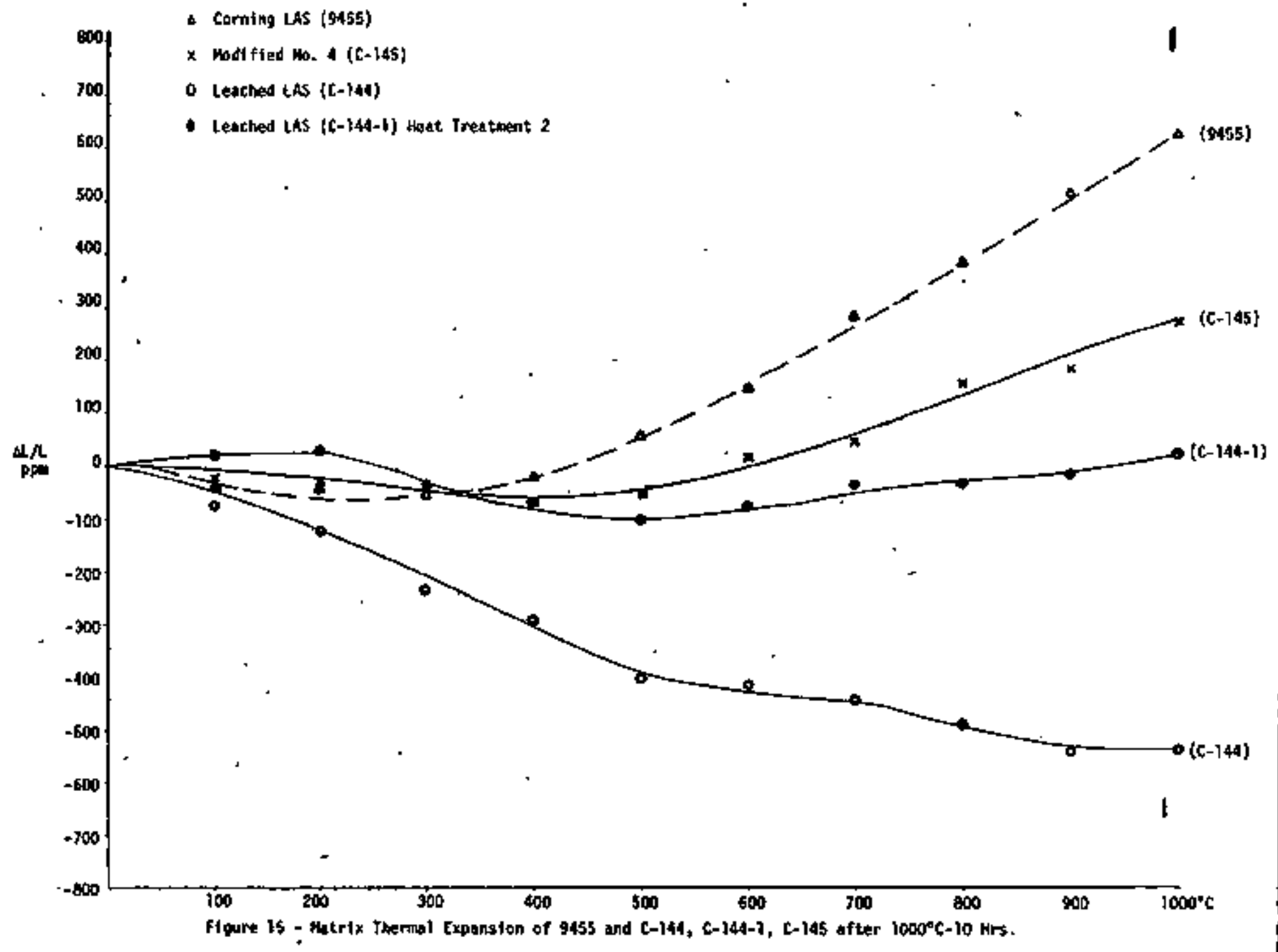




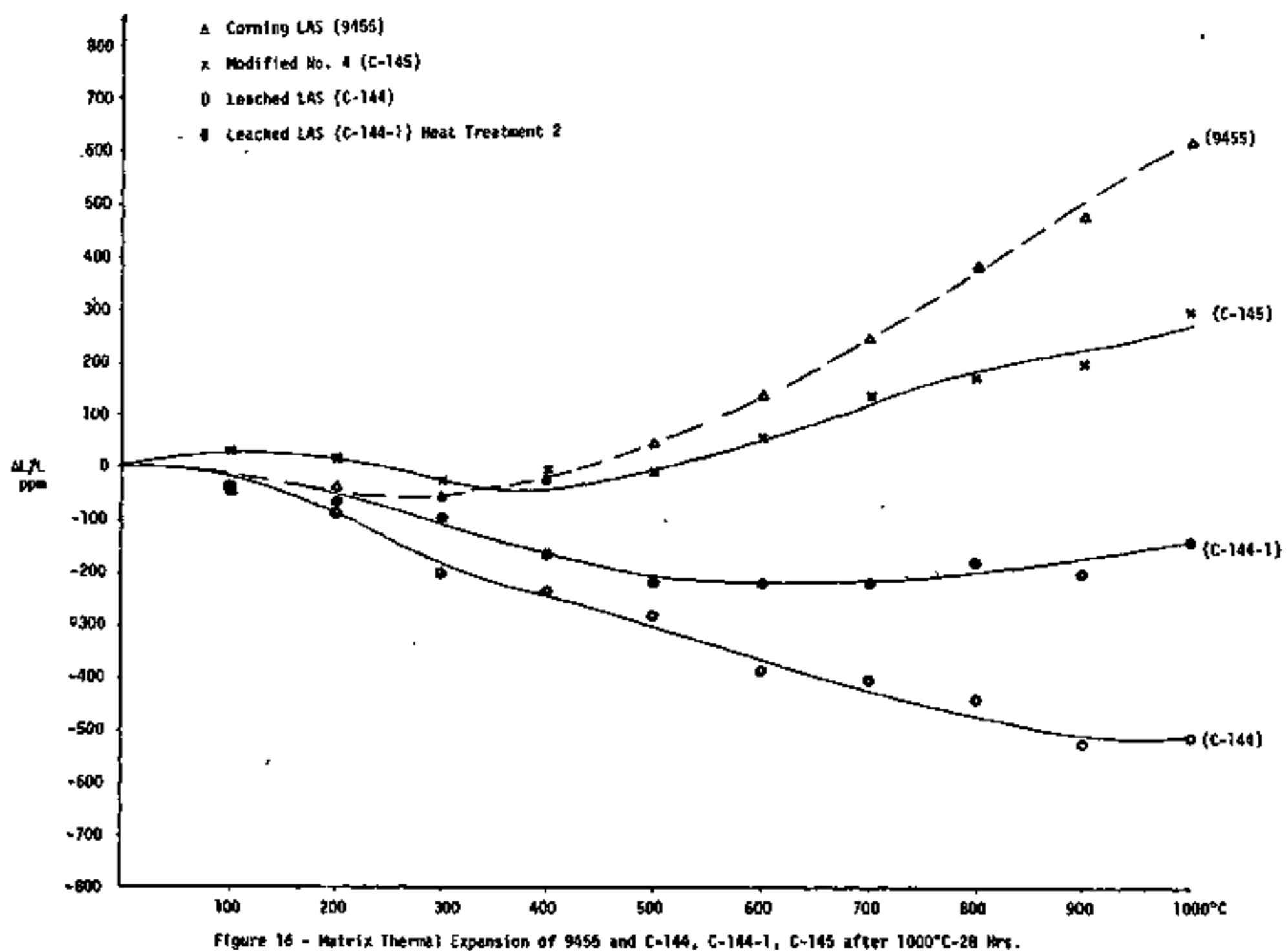




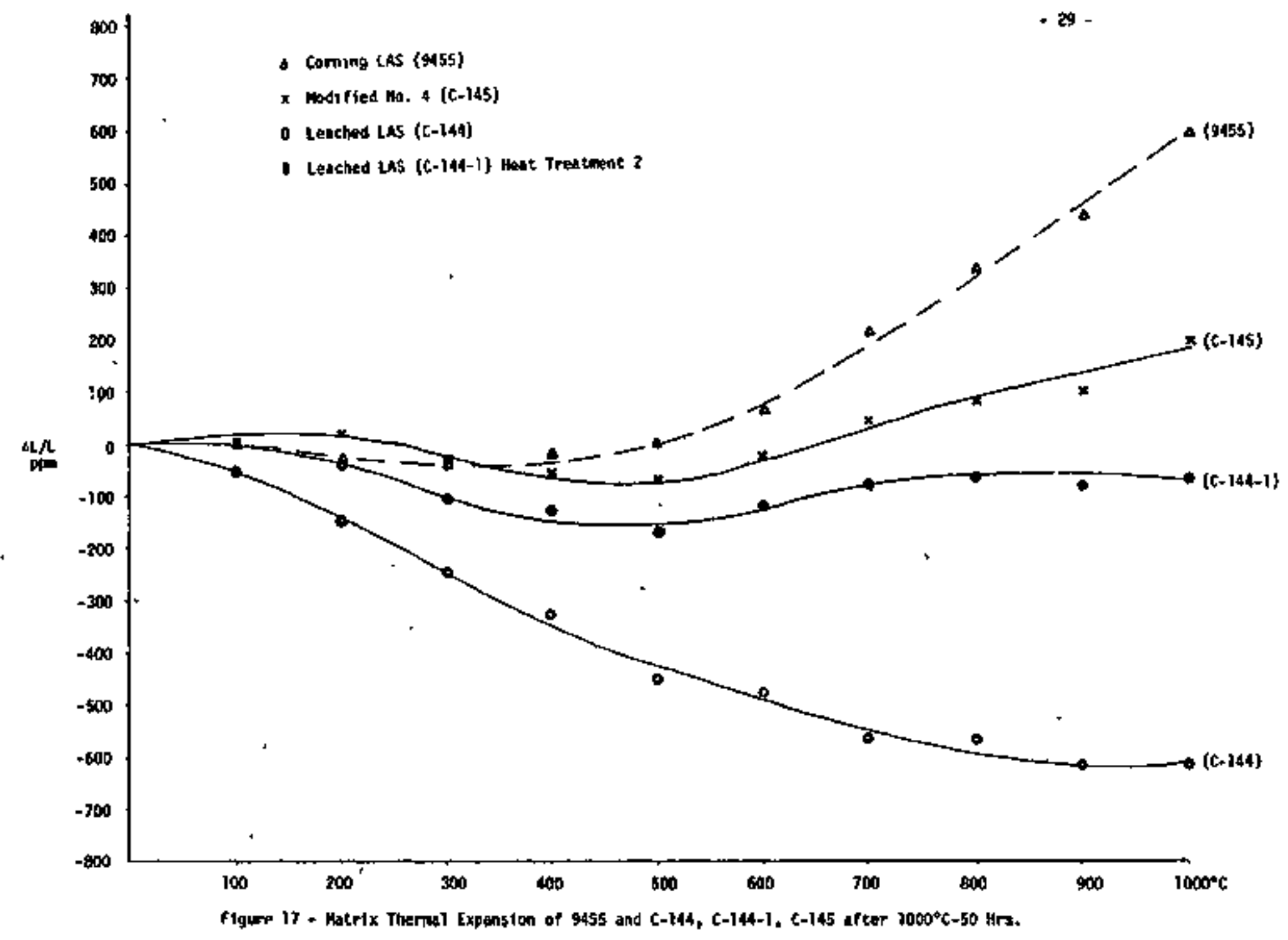




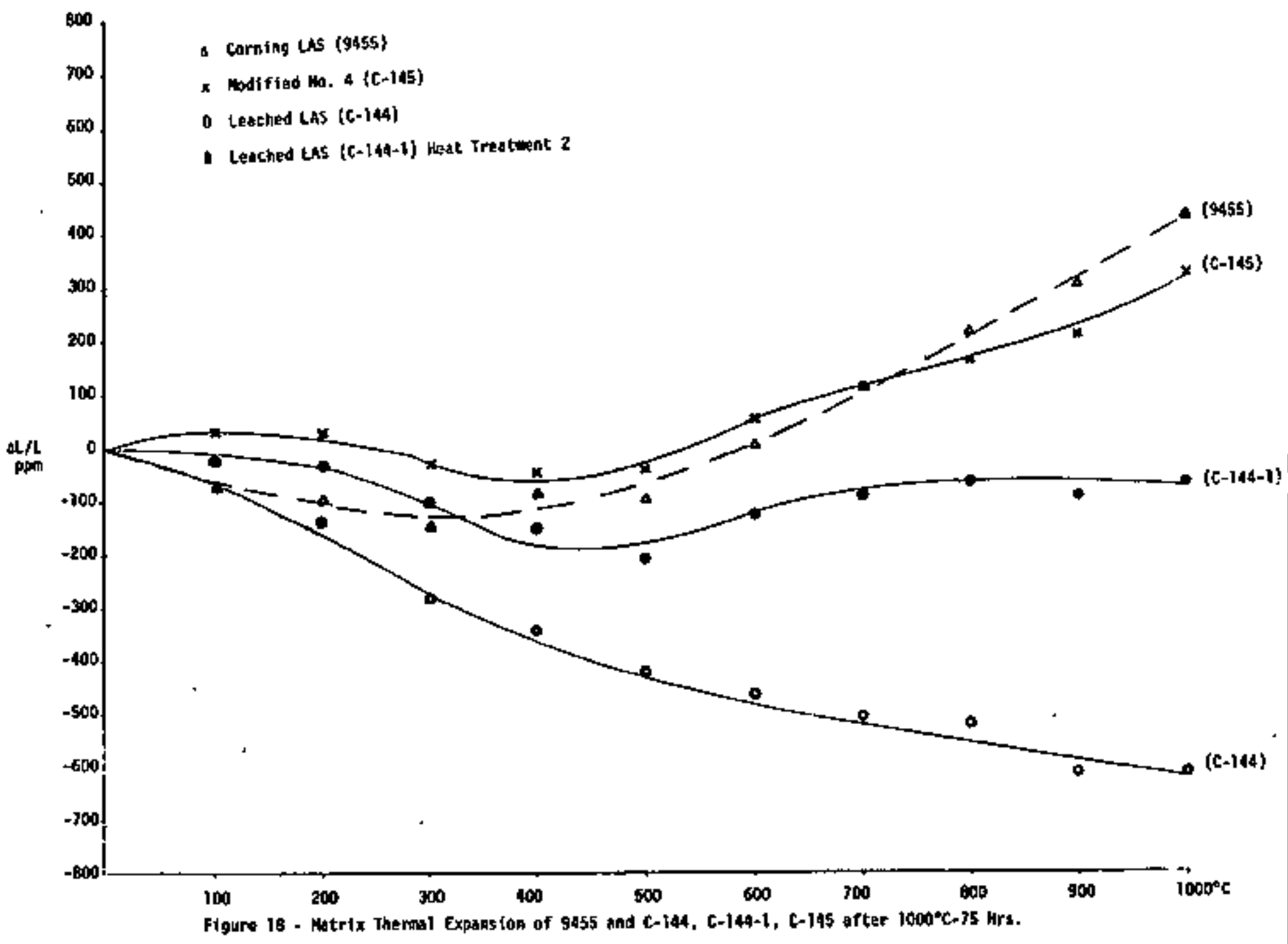




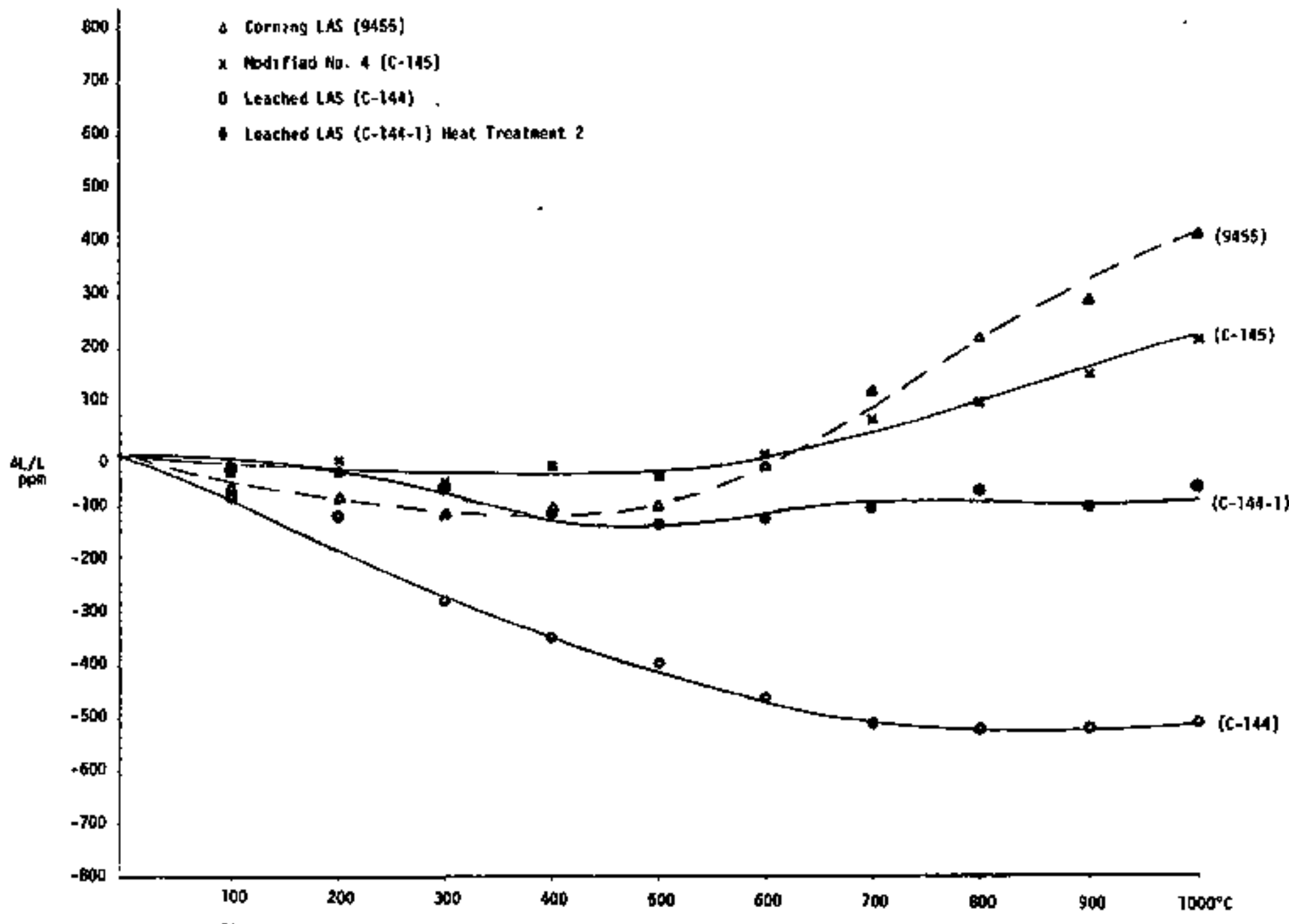

Figure t9 - Matrix Theraid Eyponsion of 945s and $\varepsilon-144, \mathrm{C}-144-1, \mathrm{C}-145$ after $1000^{\circ} \mathrm{C}-100$ Hrs. 


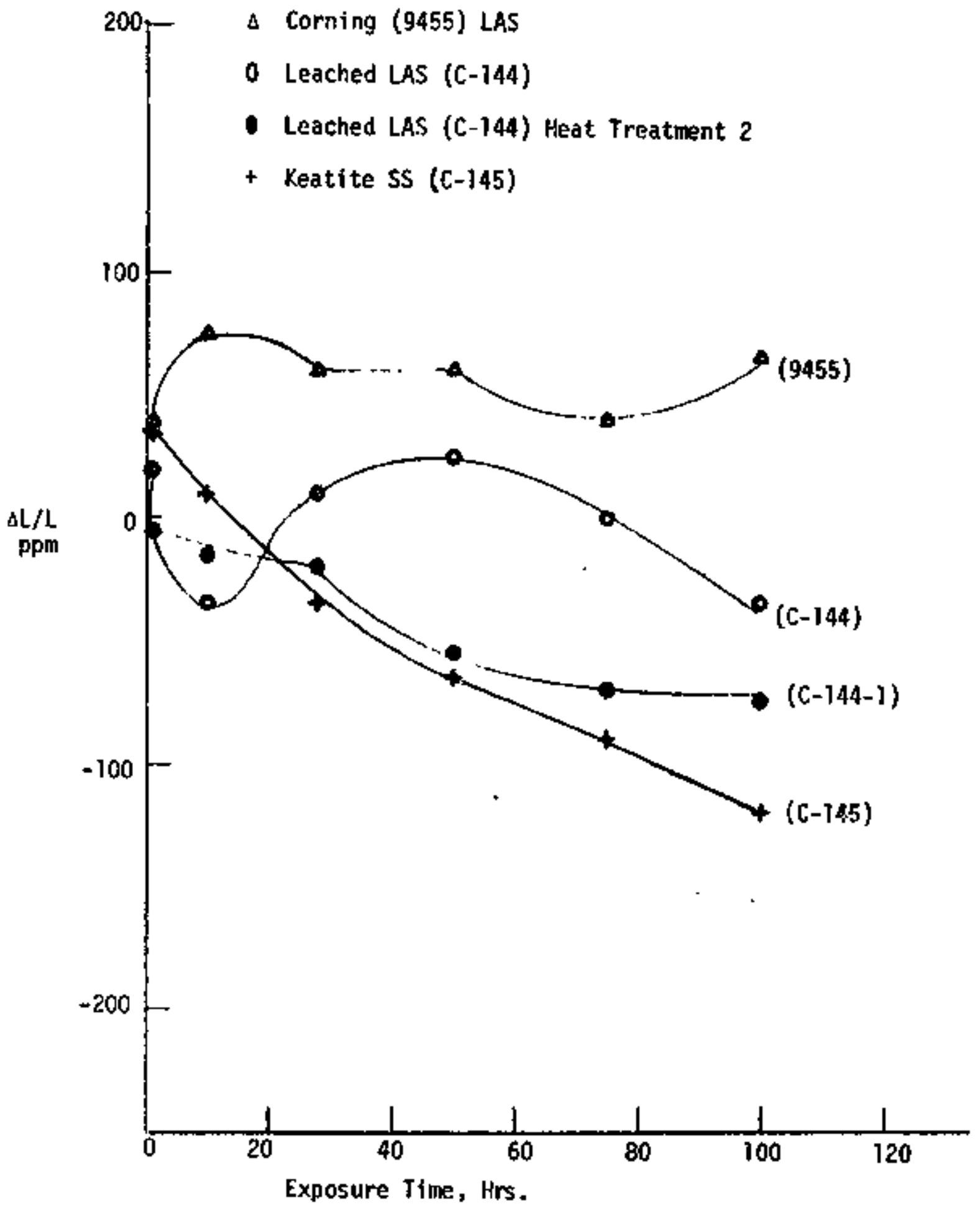

Figure 20 - Matrix 0imensional Stabtlity at $1000^{\circ} \mathrm{C}$, Length Change after Exposure. 

FIGURE 13. GLASS-CERAMIC MATERIALS

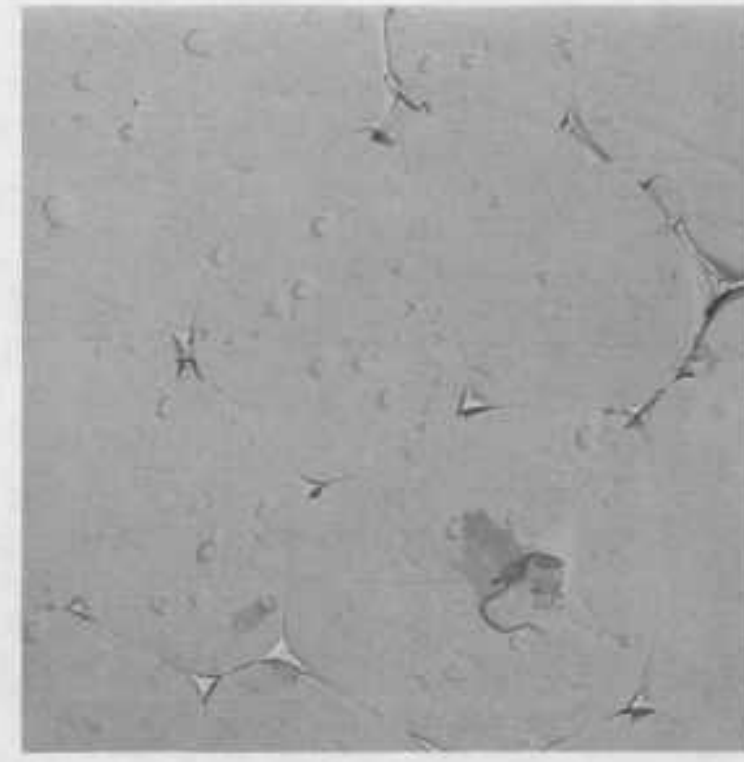

1

MATERIAL 1

LMAS Quartz SS

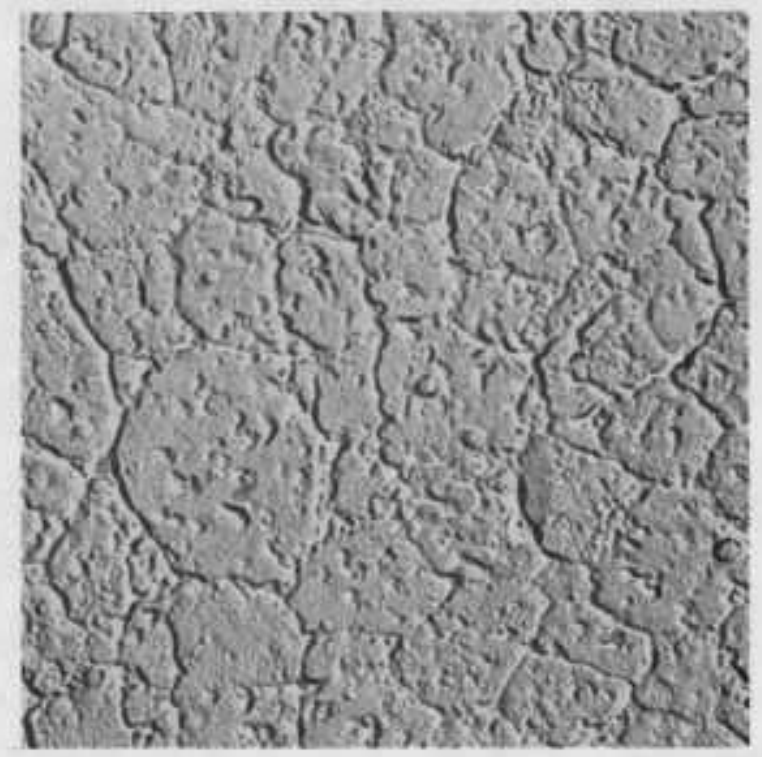

$1 \mu$

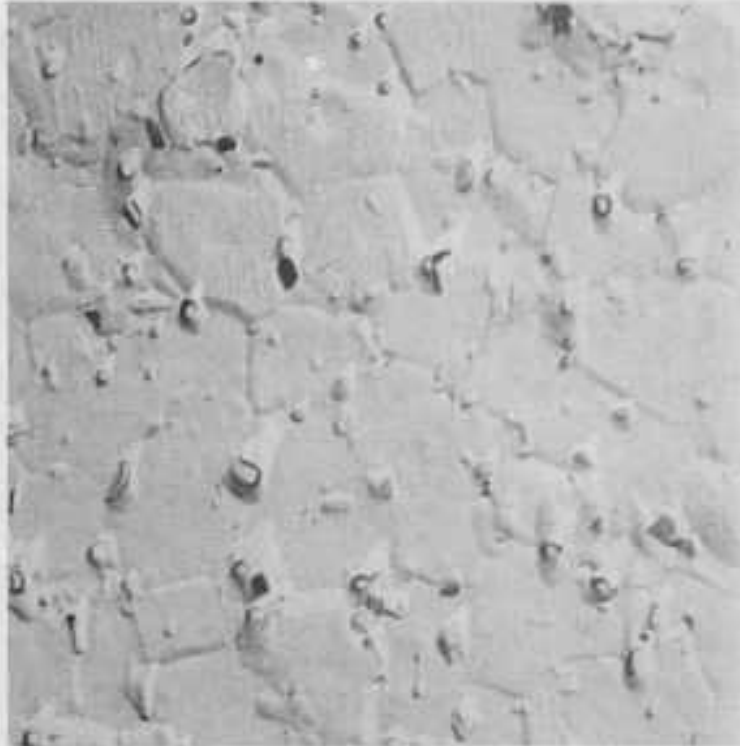

$1 \mu$

MATERIAL 2

Keatite SS + Mullite

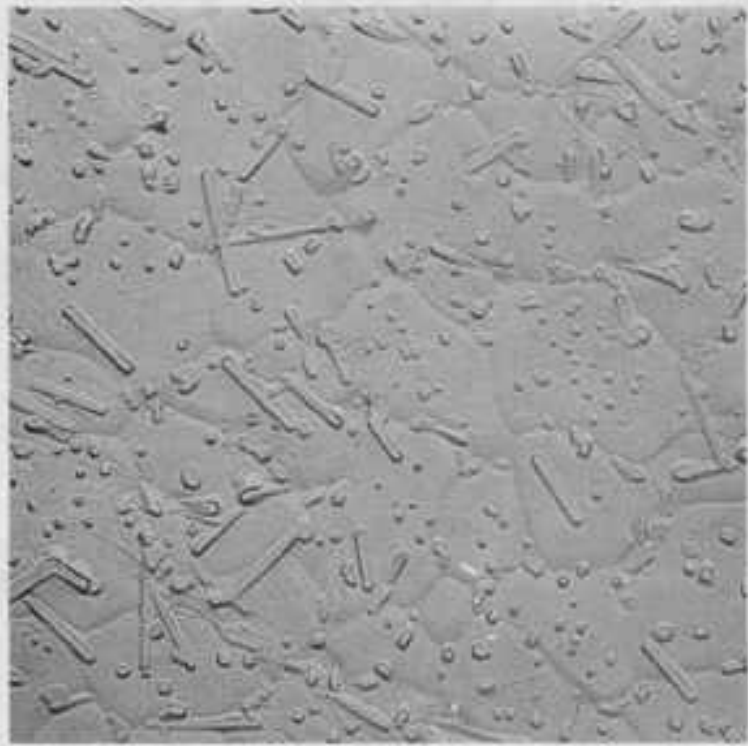

1 น

C-145

Keatite SS 